\title{
Fire Protection Research for DOE Facilities: FY 83 Year-End Report
}

\author{
H. K. Hasegawa, N. J. Alvares,
}

A. E. Lipska-Quinn, D. G. Beason,

K. L. Foote, S. J. Priante, and K. Staggs

Manuscript date: August 2, 1984

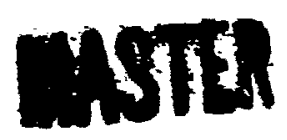

LAWRENCE LIVERMORE NATIONAL LABORATORY University of California - Livermore, California - 94550 


\section{Contents}

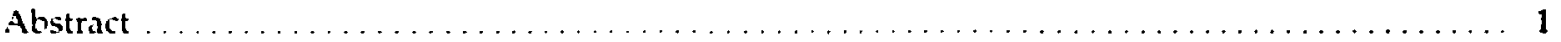

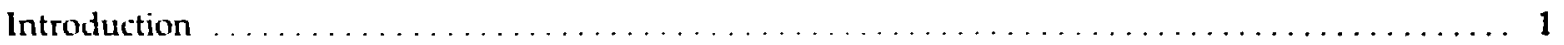

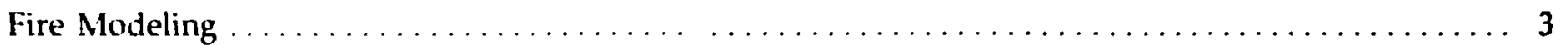

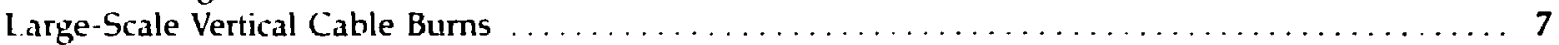

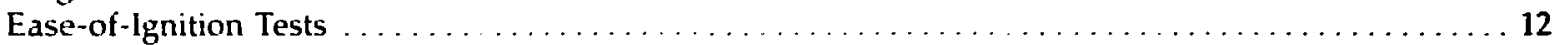

Fire Chemistry: Thermal Degradation of Cable and Wire Insulations $\ldots \ldots \ldots \ldots \ldots \ldots \ldots \ldots \ldots 17$

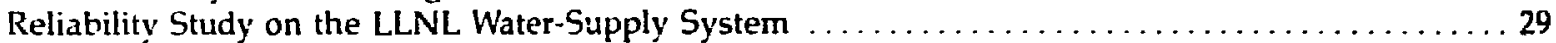

Acknowledgments . . . . . . . . . . . . . . . . . . . . . . . . . . . . . . . 39

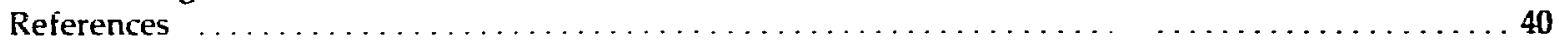

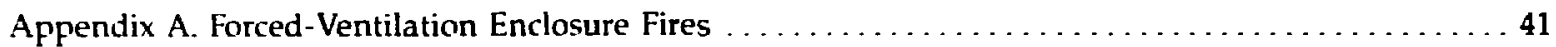

Appendix B. Mocho Standpipe Digraph . . . . . . . . . . . . . . . . . . . . 63

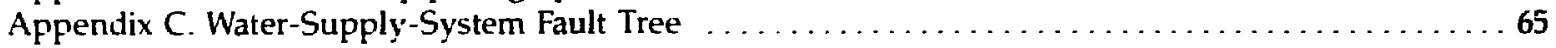




\title{
Fire Protection Research for DOE Facilities: FY 83 Year-End Report
}

\begin{abstract}
We summarize our research in FY 83 for the DOE-sponsored project, Fire Protection Research for DOE Facilities. This research program was initiated in 1977 to advance fireprotection strategies for energy technology facilities in order to keep abreast of the unique fire problems that develop along with energy technology research. Since 1977, the program has broadened its original scope, as reflected in previous year-end reports. We are developing an analytical methodology through detailed study of fusion energy experiments at Lawrence Livermore National Laboratory (LLNL). Using these experiments as models for methodology development, we are currently advancing three major task areas: (1) the identification of fire hazards unique to fusion energy facilities, (2) the evaluation of accepted fire-management measures to meet and negate hazards, and (3) the performance of unique research into problem areas we have identified to provide input into analytical fire-growth and damage-assessment models.
\end{abstract}

\section{Introduction}

We report our work performed in FY 83 for a DOE-supported study entitled Fire Protection Researile for DOE Facilities. Previous fiscal-year reports have been published..$^{1-4}$ One ultimate goal of this study is the assessment of potential fire damage in such facilities. To accomplish this, three parameters have to be evaluated: (1) the fire-threat potential to the facility. (2) the response and effectiveness of fire-management systems, and (3) the possible fire-related damage.

The milestone chart in Fig. 1 delineates the sub-tasks (marked by bullets) that must be completed to achieve our major goals (underlined) for this program. These major goals are all necessary to the ultimate objective: a standard guide of firemanagement tactics for large DOE facilities. It is appropriate here to describe the logic and significance of each milestone as to its contribution to the final result. The sub-tasks listed under Fire Growth Parameters for Model Development are a combination of small- and large-scale fire experiments to provide appropriate input for our modeling efforts and is also a partial model-validation tool. Those sub-tasks supporting Smoke Aerosol Production and Transport; Physical and Chemical Characteristics will help define two major phenomena: (1) the potential corrosive and particulate damage to experimental components, and (2) the particulate analysis (size, distribution, etc.) that will provide insight into the response times of smoke detection systems.

The next two milestones listed in Fig. 1 ( $A d$ aptation of Modeling Technique for Fire-Risk Assessment and Adrunced Fire Management System Deielopment) integrate all results from the previous two milestones and are probably the most significant components to the program. They combine all the facets of what has been learned that can be applied to actual facilities. The modeling technique will predict the rate and extent of fire development in these facilities and the work on firemanagement systems will define how detection and suppression response to predicied fires will modify the degree of firc damage. The Adranced Fire-Management-System Development phase will concentrate on unique detection and suppression systems to deal with fire problems in DOE facilities that traditional countermeasures cannot negate.

In FY 83, we made significant progress in a number of task areas. In general, we completed our analysis of the 1982 fire-mode! data and we compared six fire models to the data from three of the 1982 tests. In addition, two separate publications were derived from the seri 's. Toward the end of FY 83, we initiated an $198,-1984$ series of 
Fire Growth Parameters for Model Development

- Full-scale experiments with mixture real fuels

- Define and apply selected model to variety of DOE facilities (Critical Enclosures only)

Smoke Aerosol Production and Transport;

Physical and Chemical Characteristics

- Smoke balance experiments - small-scale

- Critical effects of combustion conditions and heat on composition and physical structure of smoke aerosols

- Time and dilution effects on physical and chemical smoke aerosols

- Smoke corrosion and transport criteria

Adapt Modeling Technique for Fire-Risk Assessment of Energy Technology Research Facilities

- Relate fire and smoke growth rate parameters to response and performance of hypothetical fire management systems

- Develop recommendations for optimum fire management systems based on specific fire environments

- State of art fire management relative to risk

Advanced Fire Management System Development

- Design and test prototype arrays of extinguishing systems for compatibility in dispensing several different agents or combinations of agents

- Smart FMS design for multi applications

First Draft of Standard Guide of Fire-Management Tactics for Large Energy Research Facilities

- Develop standard guide to usable document (slide rule) (code)

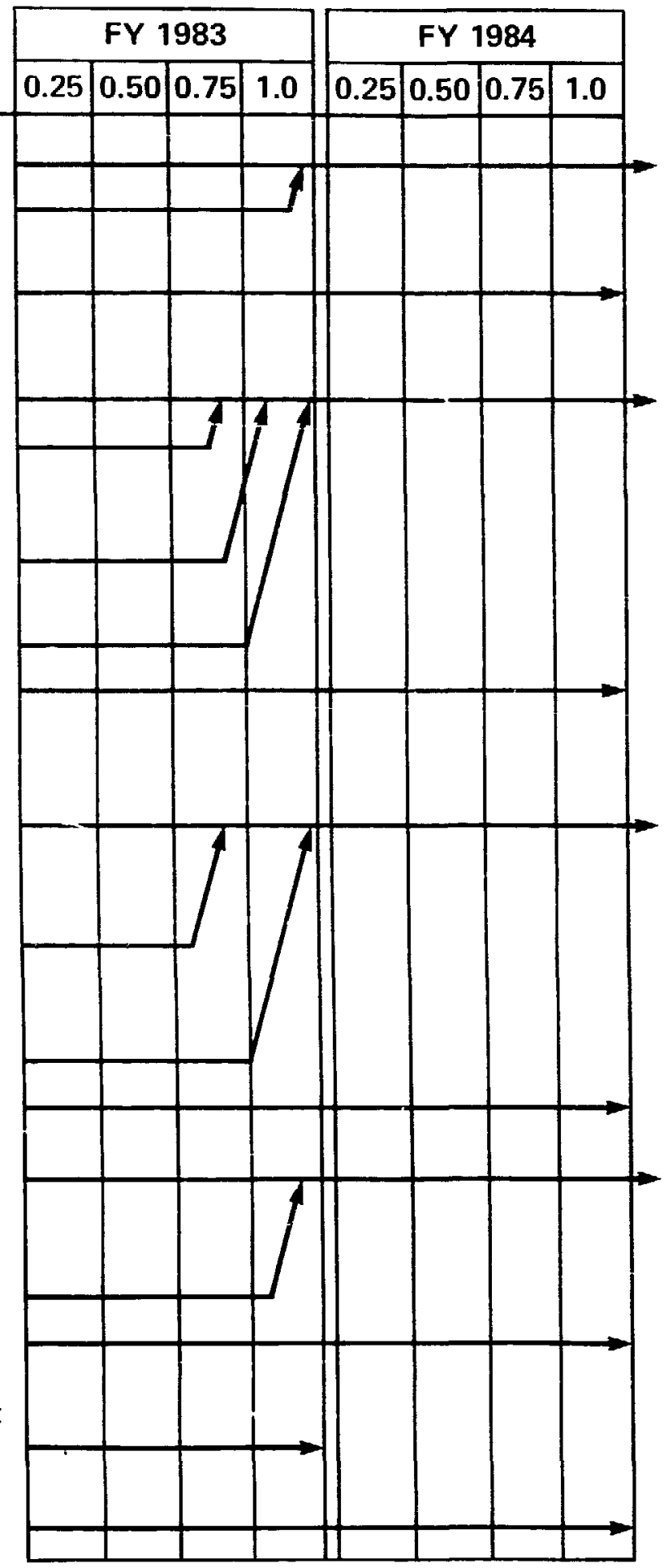

Figure 1. Descriptive chart of project milestones for LLNL fire-protection research for DOE facilities. 
widely varying fire-model tests using improved instrumentation and metholology. The results from our FY 82 test series led us to a research plan that we pursued for cable insulations in our Easeof-Ignition apparatus. We found. nonconclusively, that ignition times of some cable types can be predicted from certain physical characteristics. At the same time, we performed 17 large-scale vertical cable burns using the FY 82 research protocol. The results reconfirmed our FY 82 findings.

In the area of chemical characteristics of smoke aerosol, we started and completed hightemperature studies on the Lawrence Livermore National Laboratory (LLNL) inventory of insula- tions by thermogravimetric analysis, differential scanning calorimetry, and gas chromatographic/ mass spectrometry. We also started and completed detailed analyses of Teflon and Kynar wire insulations.

Finally, although not listed as a specific milestone, we completed a reliability analysis of the LLNL water-supfly system in the event of a major fire. This study falls under the major heading of Adopt Modeling Technuques for Fire-Risk Assessment of Energy Technology Research Facilities. We used the Digraph-Fault Tree technique, which can analyze a variety of complicated systems, such as reactor-cooling systems and nuclear-materialsafeguard systems.

\section{Fire Modeling}

Our FY 81 and 82 year-end reports have already described the objectives of our efforts to create a versatile computer model that simulates fires in a forced-ventilation enclosure. ${ }^{1.2}$ Here, we cover the final conclusions from an analysis of the 1982 fire-model tests, compare six fire model's predictions with the 1982 tests, and discuss the 1983 fire-model tests.

In 1982, we completed 27 fire-model validation studies and started an analysis of same. We finished this analysis in 1983 . This involved careful checking of air and fuel flows, balancing the gas species present, and analyzing wall thermocouples. We presented these findings in a paper at a National Bureau of Standards' meeting that honored Howard Emmons. 'This paper is included in its entirety as Appendix A. The most important conclusions were that up to $80 \%$ of the energy from the fires is absorbed by the enclosure walls, that over $2000 \mathrm{~s}$ are required to reach "chemical equilibrium" in our test cell, and that twice the stoichiometric amount of air is required for total combustion of the fuels we used.

We chose 3 of the 1982 tests (Tests 8, 9, and 27B) for 6 model-validation comparisons. Our results indicate that these models need significant improvements in order to correctly predict the $\mathrm{Fa}^{\mathrm{a}}$ rameters of a fire in our forced-ventilation enclosure. The difficulty of such model improvements and the time required to complete them is not known. The comparisons and soon-to-beanalyzed 1983-1984 results should, however, speed up this process.

Even though we found all of the current versions lacking in some respects, we ranked them as to their "friendliness" and utility to our goals. This is the ranking as follows: California Institute of Technology one-layer model (Cal Tech I), Battelle Pacific Northwest Laboratories' model (PNL), the Harvard model, the Los Alamos National Laboratory model (LANL), Cal Tech two-layer modei (Cal Tech 11), and the LLNL model. In the past year, we experimented with two of the models; both models used the Cal Tech entrainment code and were difficult to modify. We acquired and rewrote the Cal Tech I model, a relatively small code, so we could run and modify it ourselves as necessary.

The analysis of the 1982 experimental data pointed out many problems in our experimental approach, one of which was elucidating enclosure-fire characteristics more fully. Table 1 lists the problems of the 1982 experimental series and the improvements we applied to the 1983-1984 forced-ventilation tests. The most significant changes were to the gas analysis and airflow systems. Leaks in the test cell and the duct were plugged, and the HEPA filter was removed to improve the airflow measurements. More gas analyzers were added and a different calibration and sampling system was used triat made the $\mathrm{O}_{2}, \mathrm{CO}_{2}$, and $\mathrm{CO}$ measurements ore reliable. All the improvements combin \& make the 1983 fire-model tests the best forced-ventilation data to date.

Table 2 lists 35 experiments completed in the last quarter of FY 83 and the first quarter of FY 84 . These tests investigated forced-ventilation fires near walls and in corners, as well as fires raised off the ground. We also explored the effects of the position of the inlet and exit ducts. Since most of 
Table 1. Improvements in instrumentation, calibration and techniques for 1983 model test series.

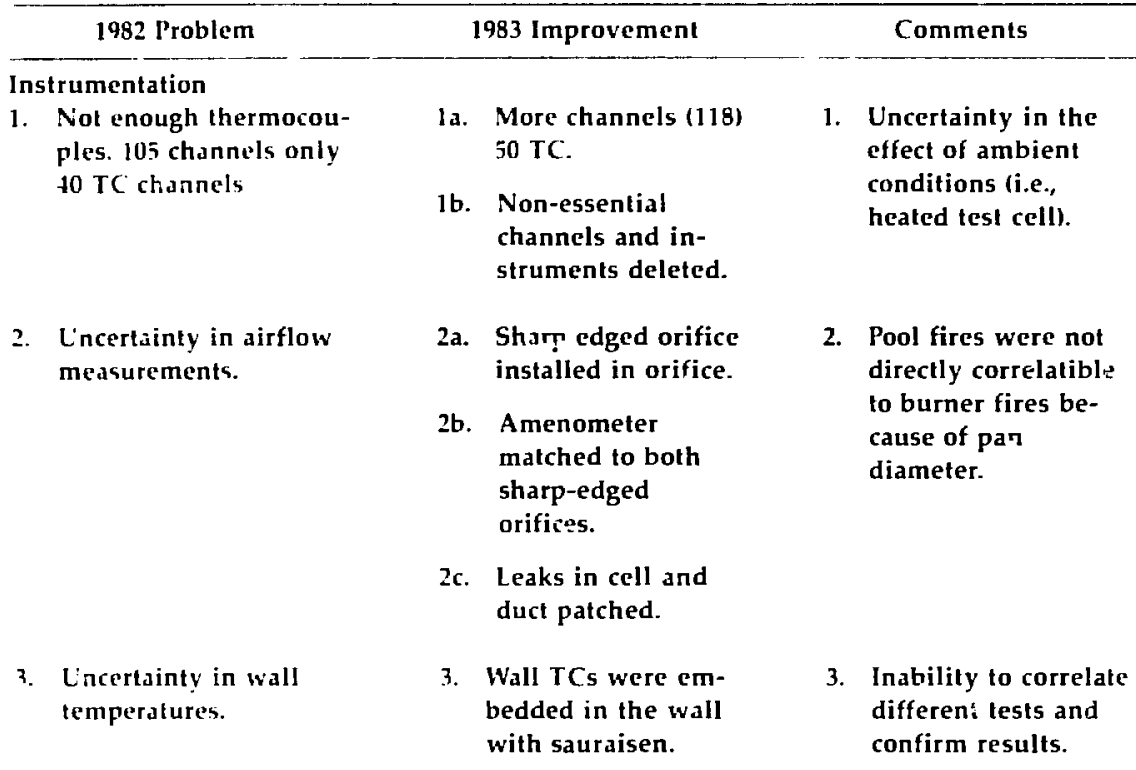

4. Uncertainty in gas measurements.
5. $\mathrm{CH}_{4}$ burner too small (Dia - $30 \mathrm{~cm}$ ) created momentum jet.
4a. O, analyzer added (4 total)
4b. $\mathrm{CO}_{2}$ unalyzer added ( 3 total)
4c. CO analyzer added (3 total)
4d. $\mathrm{H}_{2} \mathrm{O}$ analyzer added (1 total)

Techniques

1. Only one lest was done per day.

2. The ponl pan diameter was matched to the burner diameter.

3a. Fewer changes in fuel and fire strength.

3b. More overventilated tests.

3c. More repeated tests.

4. Some data were useless or misleading.

4a. $\mathrm{O}_{2}$ analysis moved from test cell floor to midpoint of room.

4b. The test cell walls were divided into zones with equal areas that could better account for the geometry of the test cell.

4c. Wall TC's were repositioned throughout the test cell in each of the new zones instead of on just one wall.

4d. Radiometers and calorimeters were repositioned to measure the fire not the layer.

4e. Turbidity meters deleted. 5. Enlarged burner
(Dia $-56 \mathrm{~cm}$ )
5. Uncertainty in gas measurements.
5. Gas samples wert "pumped" into the gas analyzers instead of "pulled." This allowed fast response times and didn't build up large pressures in the analyzers to interfere with the calibration. 
Table 1. (Continued)

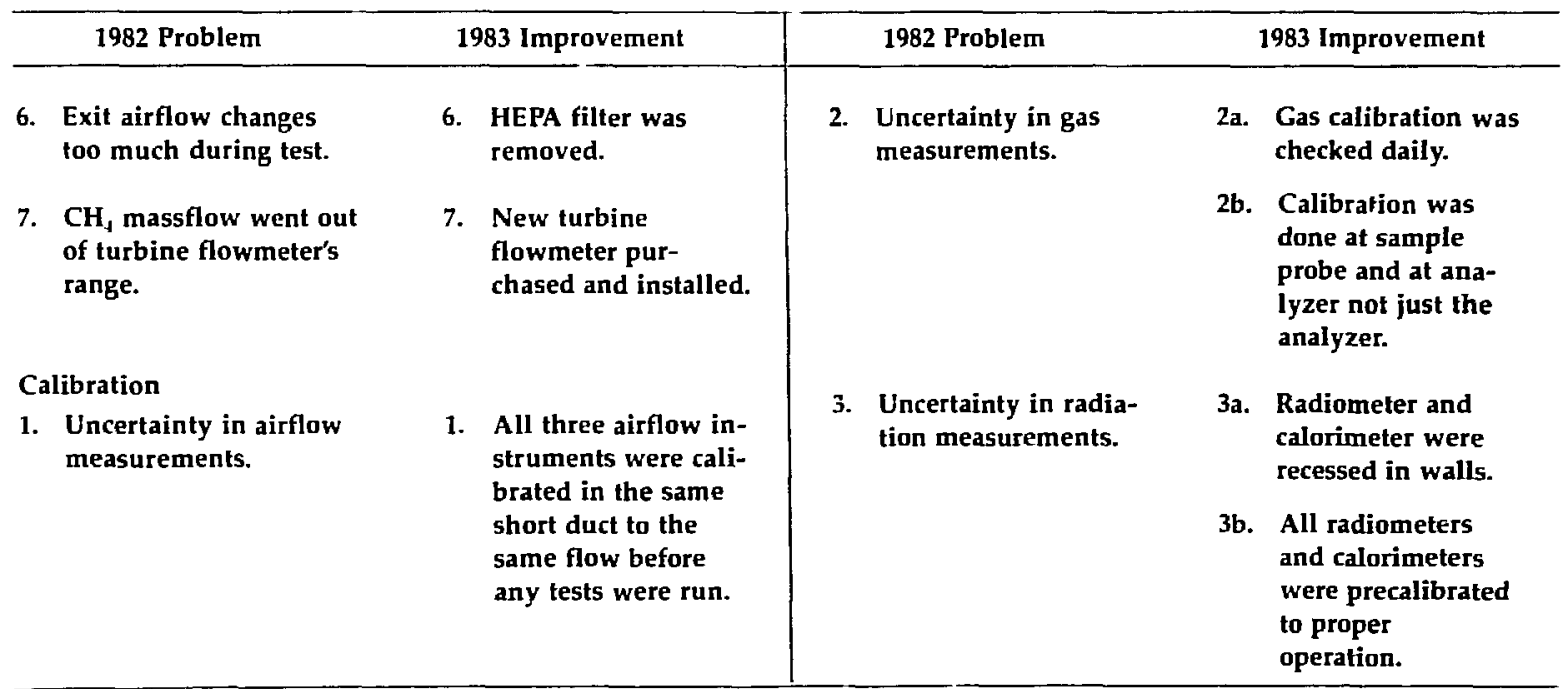

these tests were completed at the end of the year, the results will be published in a subsequent report. The 1982-1983 data represent a wide variety of forced-ventilation tests, wide enough, we feel, to validate a computer code that simulates the fire conditions in our forced-ventilation enclosure and in other DOE test cells. In 1984, we will modify existing computer codes with the data to better simulate these conditions. The code that most nearly duplicates the test data will be applied to selected enclosures to assess fire risk and define appropriate countermeasures. 
Table 2. Complete 1983 fire test series.

\begin{tabular}{|c|c|c|c|c|c|c|c|c|}
\hline Test & $\begin{array}{c}\text { Fuel } \\
\left(C_{1}, H_{\imath}, \mathrm{O}\right)\end{array}$ & $\begin{array}{l}\text { Fire } \\
\text { type }\end{array}$ & $\begin{array}{l}\text { Initial } \\
\text { fire } \\
\text { strength } \\
\text { (kW) }\end{array}$ & $\begin{array}{c}\text { Initial } \\
\text { ventilation } \\
\text { rate } \\
(\mathrm{gm} / \mathrm{s})\end{array}$ & $\begin{array}{l}\text { Position } \\
\text { in burner } \\
\text { room }\end{array}$ & $\begin{array}{l}\text { Height of } \\
\text { burner } \\
\text { in room } \\
(\mathrm{m})\end{array}$ & $\begin{array}{c}\text { Inlet } \\
\text { vent } \\
\text { position }\end{array}$ & $\begin{array}{c}\text { Outlet } \\
\text { vent } \\
\text { position }\end{array}$ \\
\hline 0 & $\mathrm{CH}_{1}$ & burner & 250 & 0 & $\mathrm{C}^{\prime}$ & 0.2 & $\mathbf{L o}^{\mathbf{b}}$ & $\mathrm{Hi}^{\mathrm{\prime}}$ \\
\hline 1 & $\mathrm{CH}_{4}$ & burner & 490 & 425 & C & 0.2 & Lo & $\mathrm{Hi}$ \\
\hline 2 & $\mathrm{CH}_{4}$ & burner & 490 & 225 & C & 0.2 & Lo & $\mathrm{Hi}$ \\
\hline 3 & $\mathrm{CH}_{1}$ & burner & 490 & 125 & C & 0.2 & Lo & $\mathrm{Hi}$ \\
\hline 4 & $\mathrm{CH}_{4}$ & burner & 490 & 300 & C & 0.2 & Lo & $\mathrm{Hi}$ \\
\hline 5 & $\mathrm{CH}_{4}$ & burner & 250 & 125 & $C$ & 0.2 & Lo & $\mathbf{H i}$ \\
\hline 6 & $\mathrm{CH}_{3}$ & burner & 250 & 225 & $C$ & 0.2 & Lo & $\mathbf{H i}$ \\
\hline$\vec{r}$ & $\mathrm{CH}_{4}$ & burner & 250 & 425 & C & 0.2 & Lo & $\mathrm{Hi}$ \\
\hline 8 & $\mathrm{CH}_{4}$ & burner & 490 & 225 & C & 1.0 & Lo & $\mathrm{Hi}$ \\
\hline 4 & $\mathrm{CH}_{4}$ & burner & 490 & 225 & WW & 0.2 & Lo & $\mathrm{Hi}$ \\
\hline 10 & $\mathrm{CH}_{4}$ & burner & 250 & 225 & WW & 1.0 & Lo & $\mathrm{Hi}$ \\
\hline 11 & $\mathrm{CH}_{4}$ & burner & 490 & 125 & SE. & 0.2 & Lo & $\mathrm{Hi}$ \\
\hline 12 & $\mathrm{CH}_{4}$ & burner & 490 & 225 & $C$ & 0.5 & Lo & $\mathrm{Hi}$ \\
\hline 13 & $\mathrm{CH}_{4}$ & burner & 490 & 225 & SEC & 1.0 & Lo & $\mathrm{Hi}$ \\
\hline 14 & $\mathrm{CH}_{4}$ & burner & 490 & 225 & C & 1.5 & Lo & $\mathrm{Hi}$ \\
\hline 15 & $\mathrm{CH}_{4}$ & burner & 490 & 425 & $C$ & 1.5 & Lo & $\mathrm{Hi}$ \\
\hline 16 & $\mathrm{CH}_{4}$ & burner & 490 & 225 & $c$ & 2.5 & Lo & $\mathrm{Hi}$ \\
\hline 17 & $\mathrm{CH}_{1}$ & burner & 490 & 425 & C & 2.5 & Lo & $H i$ \\
\hline 18 & $\mathrm{CH}_{1}$ & burner & 490 & 225 & $c$ & 0.2 & $\mathrm{Hi}$ & $\mathrm{Hi}$ \\
\hline 19 & $\mathrm{CH}_{4}$ & burner & 490 & 425 & C & 0.2 & $\mathrm{Hi}$ & $\mathrm{Hi}$ \\
\hline 20 & $\mathrm{CH}_{4}$ & burner & 490 & 225 & C & 0.2 & $\mathrm{Hi}^{\mathbf{t}}$ & $\mathrm{Hi}$ \\
\hline 21 & $\mathrm{CH}_{1}$ & burner & 490 & 425 & C & 0.2 & $\mathrm{Hi}$ & $\mathrm{Hi}$ \\
\hline 22 & $\mathrm{Cli}_{4}$ & burner & 250 & 425 & C & 0.2 & $\mathrm{Hi}$ & $\mathrm{Hi}$ \\
\hline 23 & $\mathrm{CH}_{\mathrm{i}}$ & burner & 250 & 225 & C & 0.2 & $\mathrm{Hi}$ & $\mathrm{Hi}$ \\
\hline 24 & $\mathrm{CH}_{4}$ & burner & 360 & 330 & $\mathrm{C}$ & 0.2 & $\mathrm{Hi}$ & $\mathbf{H i}$ \\
\hline 25 & $\mathrm{CH}_{4}$ & burner & 250 & 225 & $C$ & 0.2 & $\mathrm{Hi}$ & Lo \\
\hline 26 & $\mathrm{CH}_{4}$ & burner & 250 & 425 & C & 0.2 & $\mathrm{Hi}$ & Lo \\
\hline 27 & $\mathrm{CH}_{4}$ & burner & 250 & 425 & C & 0.2 & Lo & l.o \\
\hline 28 & $\mathrm{CH}_{\downarrow}$ & burner & 490 & 425 & C & 0.2 & Lo & Lo \\
\hline 29 & $\mathrm{C}_{1} \mathrm{H}_{\mathrm{R}} \mathrm{O}$ & pool & 150 & 425 & $\mathrm{C}$ & 0.6 & Lo & Lo \\
\hline 30 & $\mathrm{C}_{7} \mathrm{H}_{8} \mathrm{O}$ & pool & 150 & 225 & C & 0.6 & Lo & Lo \\
\hline 31 & $\mathrm{C}_{i} \mathrm{H}_{\mathrm{R}} \mathrm{O}$ & pool & 150 & 225 & $\mathrm{C}$ & 1.5 & Lo & Lo \\
\hline 32 & $\mathrm{CH}_{4}$ & burner & 250 & 225 & $c$ & 1.5 & Lo & Lo \\
\hline 33 & $\mathrm{CH}_{4}$ & burner & 250 & 425 & C & 1.5 & Lo & Lo \\
\hline 34 & $\mathrm{C}_{3} \mathrm{H}_{n} \mathrm{O}$ & pool & 180 & 225 & C & 0.6 & Lo & $\mathrm{Hi}$ \\
\hline 35 & $\mathrm{CH}_{4}$ & burner & 150 & 225 & C & 0.5 & I o & $\mathrm{Hi}$ \\
\hline
\end{tabular}

"C = center of room.

${ }^{b}$ Lo $=$ inlet air introduced low $\sim 0.2 \mathrm{~m}$.

' $\mathrm{Hi}=$ inlet air introduced high $-4.2 \mathrm{~m}$.

"WW = west wall.

" $5 E C=$ southeast corner.

' $\mathrm{Hi}=$ inlet air introduced high and directed down $-4.0 \mathrm{~m}$. 


\section{Large-Scale Vertical Cable Burns}

We conducted large-scale fire experiments to define the effect of cable size, composition, number and packing density on the vertical flame-spread rate, and, consequently, on the mass-burning rate. Although other parameters are monitored for edch test, flamespread and massburning rate are the most important. These data will be compared to results from our small-scale tests to assess the correspondence to real conditions, and be applied to models for use in fire-risk assessment. Moreover, we can obtain specific fuel performance and enclosure-fire parameters, e.g., the temperature profile along the vertical surface, the temperature distribution throughout the test cell, and the enclosure-ventilation changes resulting from the heat-release rate.

Figure 2 shows the support structure for the vertical-cable tests. The bundle of electrical conductors is suspended from a steel cable threaded over two bicycle wheels (to decrease friction) and attached to a counterbalanced load cell. Adjacent to the recimen is a vertical panel with half-meter in rements for visually monitoring the flamespread. Calorimeters and radiometers are located at the ignition source, near the specimen bottom, and at mid-height. Similarly, chromel-alumel thermocouples are located at strategic points on the specimens, apparatus, and throughout the test cell. To monitor the : elting insulation that might drip from a burning cable, a load cell is placed directly under the specimien's centerline. The weighing of cable melt is necessary to estimate mass balance and fuel-consumption rates. Thermocouples attached to specimens sense temperatures of the insulation to define heat transfer during the flamespread period.

\section{Ignition Source}

To provide a well-defined fire producing a specified heat-flux level, we constructed a premixed natural gas and air burner with gravel as a diffusion medium. This 30-cm-o.d. circular bumer produced a calibrated exposure flux of $5 \mathrm{~W} / \mathrm{cm}^{2}$ at an energy release rate of $20 \mathrm{~kW}$. A heat flux of $5 \mathrm{~W} / \mathrm{cm}^{2}$ or greater was identified as a threshold ignition energy from previous heat-release-rate experiments conducted at SRI, International. ${ }^{3}$

\section{Test Specimen}

The test specimens for this experimental series were two-iayer cable bundles formed into a perpendicular " $Z$ " configuration as shown in Fig. 3. The net vertical cable length was $1.8 \mathrm{~m}$. To prevent undefined heat-loss effects on cableburning characteristics, we designed and fabricated special low-mass hardware to hold the cables. We chose the vertical configuration to maximize the rate of flamespread and simulate a worst-case situation. To supplement our visual observations of fire growth, we attached thermocouples in a vertical array at approximately $0.4-\mathrm{m}$ intervals on both faces of the specimens.

\section{Experimental Notes}

We performed the experiments in the LLNL Fire-Test Cell, an extraction-ventilation enclosure with a $4.7-\mathrm{m}$ ceiling height and a total volume of $100 \mathrm{~m}^{3}$. In FY 82, we performed 6 tests, and in FY 83, we completed 17 additional tests. The cables chosen for the FY 83 series were based on the results of the FY 82 tests. Table 3 lists the cable types, their pertinent physical characteristics, and packing densities.

To evaluate the effects of decreasing the overall mass and increasing the cable spacing, we conducted tests on three separate bundles for each cable type shown in Fig. 4. The first specimen was normally a full cable run ( $100 \%$ pack) that averaged 20 cables in 2 layers, with a net vertical run of $1.8 \mathrm{~m}$. The second specimen contained half this number ( $50 \%$ pack), which allowed for a 1-cable diameter space between each cable. The third specimen contained half this number, or approximately 5 cables ( $25 \%$ pack), in a single layer.

The heat-release rate during these experiments were calculated using both the mass-loss and oxygen-depletion rates; but, due to the high ventilation rate $(500 \mathrm{~L} / \mathrm{s})$ and sparse cable burning, only the mass-loss rate provided usable data. Consequently, the heat-release rates for the various experiments were derived from the mass-loss rate. Because many of the cable types are composed of several different polymeric materials, we had to use an average value for heat of combustion of the composite.

Table 4 summurizes the results from the cable series. The data show that the FY 83 results echoed the FY 82 burns. Specifically, the majority of cable types producer slow flamespread rates, low heat-release rates, and extended ignition times. 


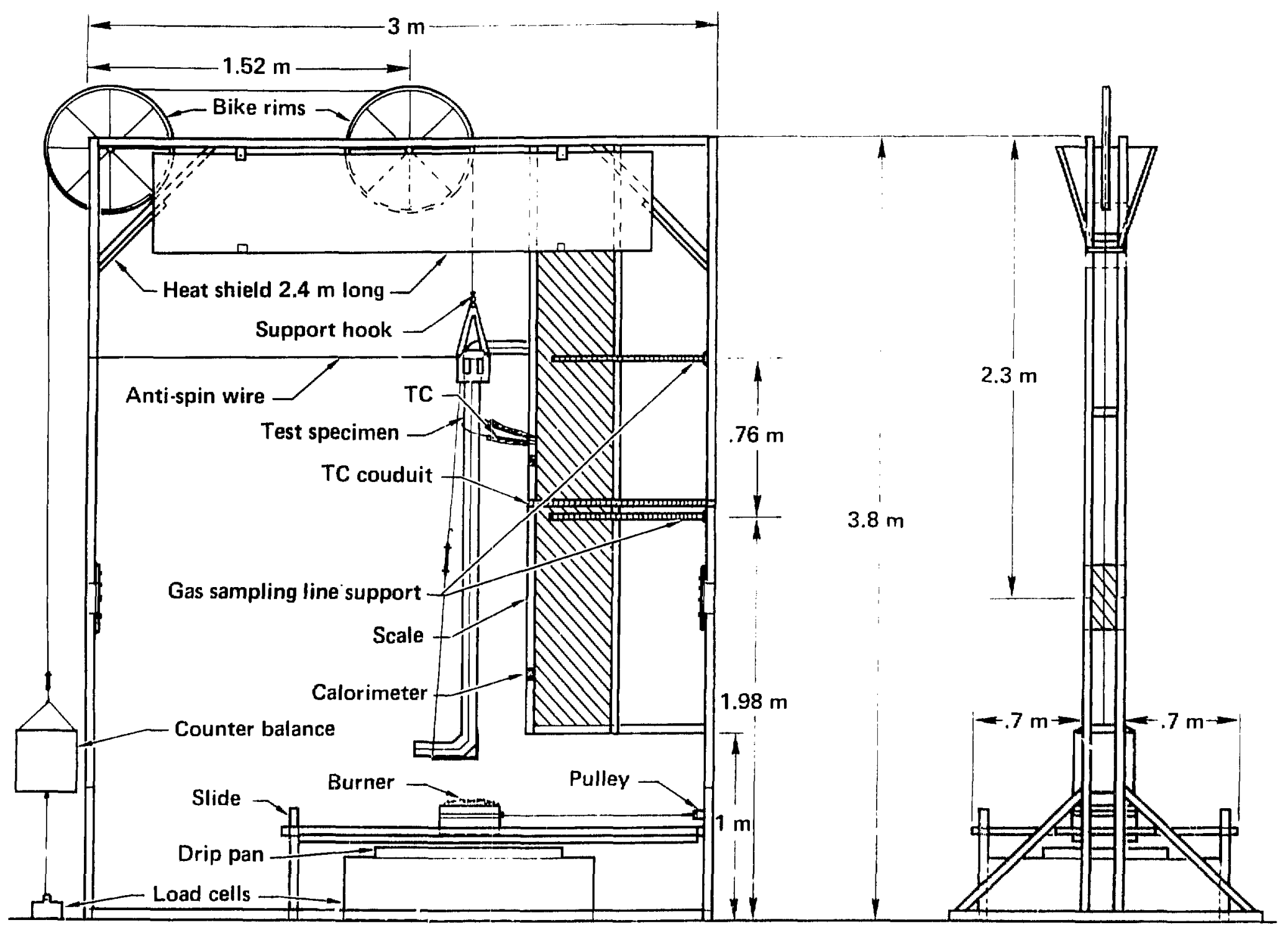

Figure 2. Experimental support structure for vertical cable burn (VCAB) experiments (TC $=$ thermocouple). 


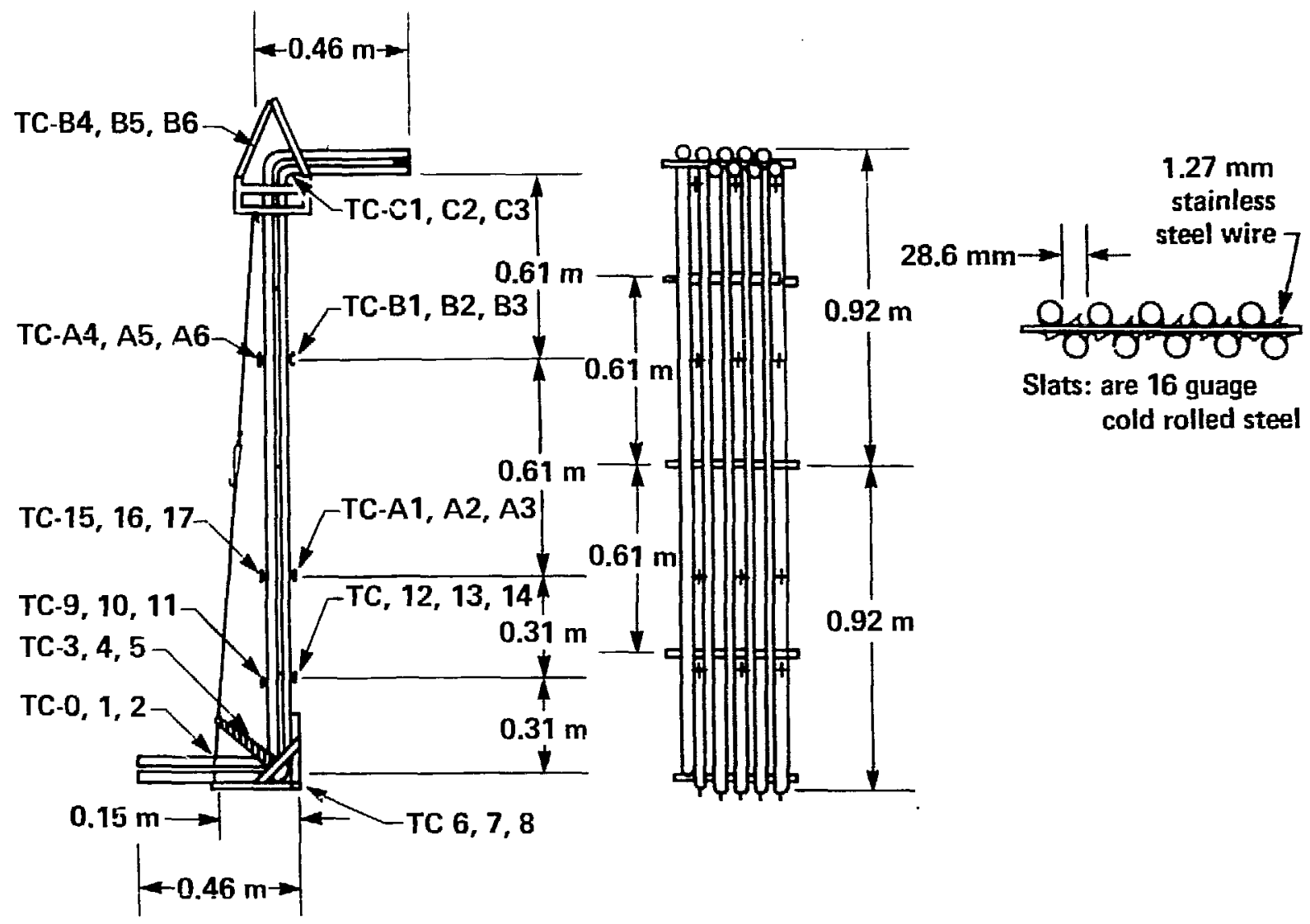

Figure 3. Thermocouple (TC) locations for vertical cable burns.

However, Tests 10-12, which were polyvinylchloride (PVC) multiconductors, produced relatively fast flamespread rates that covered the entire cable run. Also, these three produced consistently higher peak and average heat-release rates.

\section{General Observations}

- The 50\%-pack configuration produced the highest heat-release rate for most cable types.

- When exposed to the $20-\mathrm{kW}$ exposure fire, the maiority of cables were very difficult to ignite. very slow.
- In most cases, the extent of flamespread was only a fraction of the vertical section.

- Heat-release rates remained low and were slow to peak.

- Fire performance correlates to the cable diameter $(1.25$ to $2.54 \mathrm{~cm})$, the percentage of conducior, and the packing density.

- Multiconductor cables generally have less fire resistance.

In the next fiscal year, only critical experiments relating to flamespread, cable heat transfer, and cable heat-release rate are scheduled. With this data, we intend to define simple flamespread and heat-release-rate growth models as input for the enclosure-fire model we will select as a riskanalysis tool. 
Table 3. Summary of cable types tested to date.

\begin{tabular}{|c|c|c|c|c|c|c|}
\hline Test & $\begin{array}{c}\text { Jacket mat'l } \\
\text { (wt \%) }\end{array}$ & $\begin{array}{l}\text { Insulation } \\
(w t / c)\end{array}$ & $\begin{array}{l}\text { Conductor } \\
\text { (wt } \%)\end{array}$ & $\begin{array}{c}\text { Cable } \\
\text { o.d. (mm) }\end{array}$ & $\begin{array}{l}\text { Tolal wt } \\
(\mathrm{kg} / \mathrm{m} \text {, }\end{array}$ & $\begin{array}{c}\% \\
\text { packing }\end{array}$ \\
\hline 1,2 & $\begin{array}{c}\text { Hypalon } \\
16.2\end{array}$ & None & $\begin{array}{c}\text { Copper } \\
83.8\end{array}$ & 19.1 & 1.15 & 100 \\
\hline 3 & $\begin{array}{l}\text { Neoprene } \\
23.5\end{array}$ & None & $\begin{array}{l}\text { Copper } \\
76.5\end{array}$ & 19.1 & 1.29 & 100 \\
\hline 4 & $\begin{array}{l}\text { PVC } \\
18.9\end{array}$ & $\begin{array}{l}\text { P.E. } \\
32.1\end{array}$ & $\begin{array}{c}\text { Copper } \\
49.0\end{array}$ & 25.5 & 1.12 & 100 \\
\hline 5 & $\begin{array}{l}\text { PVC } \\
18.9\end{array}$ & $\begin{array}{l}\text { P.E. } \\
32.1\end{array}$ & $\begin{array}{c}\text { Copper } \\
49.0\end{array}$ & 25.5 & 1.12 & 50 \\
\hline 6 & $\begin{array}{l}\text { PVC } \\
18.9\end{array}$ & $\begin{array}{l}\text { P.E. } \\
32.1\end{array}$ & $\begin{array}{c}\text { Copper } \\
49.0\end{array}$ & 25.5 & 1.12 & 25 \\
\hline 7 & $\begin{array}{c}\text { Neoprene/rubber } \\
31.0\end{array}$ & None & $\begin{array}{c}\text { Copper } \\
69.0\end{array}$ & 23.6 & 1.39 & 100 \\
\hline 8 & $\begin{array}{c}\text { Neoprene/rubber } \\
31.0\end{array}$ & None & $\begin{array}{c}\text { Copper } \\
69.0\end{array}$ & 23.6 & 1.39 & 50 \\
\hline 9 & $\begin{array}{c}\text { Neoprene/rubber } \\
31.0\end{array}$ & None & $\begin{array}{c}\text { Copper } \\
69.0\end{array}$ & 23.6 & 1.39 & 25 \\
\hline 10 & $\begin{array}{l}\text { PVC } \\
27\end{array}$ & $\begin{array}{c}\text { PVC-multi } \\
16\end{array}$ & $\begin{array}{c}\text { Copper } \\
57\end{array}$ & 17.5 & 0.58 & 100 \\
\hline 11 & $\begin{array}{l}\text { PVC } \\
27\end{array}$ & $\begin{array}{c}\text { PVC-multi } \\
16\end{array}$ & $\begin{array}{l}\text { Copper } \\
57\end{array}$ & 17.5 & 0.58 & 50 \\
\hline 12 & $\begin{array}{c}\text { PVC } \\
27\end{array}$ & $\begin{array}{c}\text { PVC-multi } \\
16\end{array}$ & $\begin{array}{l}\text { Copper } \\
57\end{array}$ & 17.5 & 0.58 & 25 \\
\hline 13 & $\begin{array}{c}\text { Neoprene } \\
30.3\end{array}$ & $\begin{array}{c}\text { Rubber-multi } \\
26.5\end{array}$ & $\begin{array}{c}\text { Copper } \\
43.0\end{array}$ & 20.6 & 0.21 & 50 \\
\hline 14 & $\begin{array}{l}\text { Neoprene } \\
30.3\end{array}$ & $\begin{array}{c}\text { Rubber-multi } \\
26.5\end{array}$ & $\begin{array}{c}\text { Copper } \\
43.0\end{array}$ & 20.6 & 0.21 & 25 \\
\hline 15 & $\begin{array}{l}\text { Neoprene } \\
30.3\end{array}$ & $\begin{array}{c}\text { Rubber-multi } \\
26.5\end{array}$ & $\begin{array}{c}\text { Copper } \\
43.0\end{array}$ & 20.6 & 0.21 & 100 \\
\hline 16 & $\begin{array}{l}\text { Rubber } \\
22.35\end{array}$ & None & $\begin{array}{l}\text { Copper } \\
\mathbf{7 7 . 5 2}\end{array}$ & 21.2 & 1.26 & 50 \\
\hline 17 & $\begin{array}{l}\text { Rubber } \\
22.35\end{array}$ & None & $\begin{array}{c}\text { Copper } \\
\mathbf{7 7 . 5 2}\end{array}$ & 21.2 & 1.26 & 25 \\
\hline 18 & $\begin{array}{l}\text { Rubber } \\
22.35\end{array}$ & None & $\begin{array}{c}\text { Copper } \\
77.52\end{array}$ & 21.2 & 1.26 & 100 \\
\hline 19 & $\begin{array}{c}\text { Rubber/Hypalon } \\
\text { (22.05) }\end{array}$ & None & $\begin{array}{l}\text { Copper } \\
(77.95)\end{array}$ & 24.2 & 266 & 50 \\
\hline 20 & $\begin{array}{c}\text { Rubber/Hypalon } \\
(22.05)\end{array}$ & None & $\begin{array}{l}\text { Copper } \\
(77.95)\end{array}$ & 24.2 & 2.66 & 25 \\
\hline 21 & $\begin{array}{c}\text { Nylon/PVC } \\
(10.34)\end{array}$ & None & $\begin{array}{l}\text { Copper } \\
(89.66)\end{array}$ & 22.5 & 1.8 & 100 \\
\hline 22 & $\begin{array}{c}\text { Nylon/PVC } \\
(10.34)\end{array}$ & None & $\begin{array}{l}\text { Copper } \\
(89.66)\end{array}$ & 22.5 & 1.8 & 50 \\
\hline 23 & $\begin{array}{c}\text { Nylon/PVC } \\
(10.34)\end{array}$ & None & $\begin{array}{l}\text { Copper } \\
(89.66)\end{array}$ & 22.5 & 1.8 & 100 \\
\hline
\end{tabular}




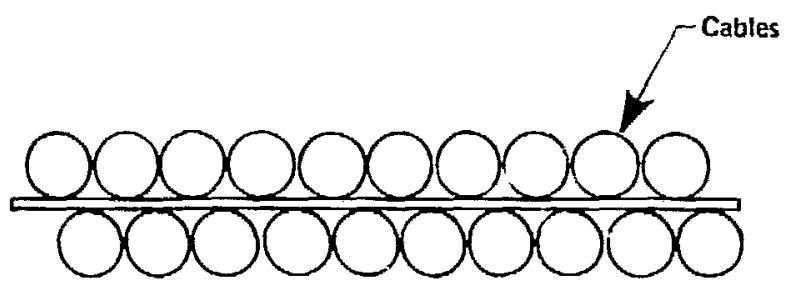

100\% pack

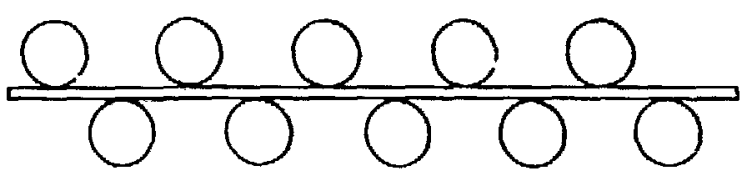

$50 \%$ pack

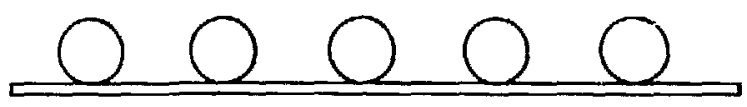

25\% pack

Figure 4. End view of test cable bundles showing different packing densities.

Table 4. Results of large-scale vertical cable burns.

\begin{tabular}{|c|c|c|c|c|c|}
\hline Test & $\begin{array}{c}\text { Max } \\
\text { hrr } \\
(\mathbf{k W})\end{array}$ & $\begin{array}{c}\text { Time } \\
\text { (s) }\end{array}$ & $\begin{array}{c}\text { Average } \\
\text { hrr } \\
\text { (kW) }\end{array}$ & $\begin{array}{c}\text { Total } \\
\text { flamespread } \\
\text { (m) }\end{array}$ & $\begin{array}{c}\text { Flamespread } \\
\text { rate } \\
(\mathrm{m} / \mathrm{min})\end{array}$ \\
\hline 7 & 65.00 & 400 & 20.00 & 0.3 & 0.05 \\
\hline B & 42.00 & 400 & 11.00 & 1.22 & 0.06 \\
\hline 9 & 4.0 & 600 & 2.5 & 1.22 & 0.13 \\
\hline 10 & 100.00 & 930 & 37.5 & 1.82 & 0.52 \\
\hline 11 & 300.00 & 660 & 53.2 & 1.82 & 0.44 \\
\hline 12 & 80.00 & 660 & 31.3 & 1.82 & 0.5 \\
\hline 13 & 2.5 & Average & 2.2 & 0.3 & - \\
\hline 14 & 9.75 & Average & 9.75 & 0.3 & - \\
\hline 15 & 4.0 & Average & 2.5 & 0.3 & - \\
\hline 16 & 75.7 & 400 & 19.95 & 0.61 & 0.03 \\
\hline 17 & 43.75 & 300 & 12.12 & 0.61 & 0.06 \\
\hline 18 & 5.29 & 1000 & 2.72 & 0.00 & - \\
\hline 19 & 100.00 & 960 & 37.5 & 0.00 & - \\
\hline 20 & 9.3 & 1000 & 6.9 & 0.61 & 0.18 \\
\hline 21 & 5.3 & 1000 & 4.2 & 0.30 & 0.14 \\
\hline 22 & 16.8 & 1000 & 8.9 & 0.61 & 0.06 \\
\hline 23 & 2.9 & 500 & 1.4 & 0.30 & 0.04 \\
\hline
\end{tabular}

${ }^{\text {a }}$ Heat-release rate. 


\section{Ease-of-Ignition Tests}

In terms of fire performance, one very important characteristic of cables is how they resist ignition. The Ease-of-Ignition apparatus is a smallscale experiment that ranks materials as a function of their ignition tımes. Such results can also help indicate relative ignition energies of materials, identifying sources that pose potential ignition threats around these materials. For fire-modeling purposes, ignition information adds data points for stochastic ignition predictions and fire growth. Our previous small-scale cable tests had problems with the wide variation of cables' physical characteristics and insulation types, the combination of which made any realistic comparisons of performance impossible. We developed a matrix of several commonly used cables to evaluate the individual effects of cable size, geometry, composition, and materials on ignitability. We tested the effect of cable size (diameter, jacket thickness, etc.) on igritability by varying the outside diameter of the cables while keeping the material and composition constant.

\section{Experimental Design}

Since our objective was establishing a correlation between a cable's physical characteristics and its time to ignition, we had to identify a matrix of cable types that were available in several different sizes. Our previous studies identified PVC. Neoprerie, and rubber as the most commonly specified cable-jacketing materials on cables used at LLNL. We selected the cables listed in Table 5 to evaluate the effect of size and configuration (i.e., multiconductor or dielectric). To ensure uniformity of jacket composition for each of the insulating materials, chemical analyses were performed for the different cable sizes.

\section{Ease-of-Ignition Test Method}

Figure 5 show's the test apparatus and related instrumentation. The only sensors used in this series were the thermopile and water temperature thermocouple (TC). Two parallel vertical specimens, $140 \mathrm{~mm}$ wide and $152 \mathrm{~mm}$ high, face each other at a separation of $53 \mathrm{~mm}$. The facing surface of both specimens are exposed to a methane diffusion flame supplied from a multiported burner located below the lower edge of the specimens. The gas flow rate through each of the independently controlled burners was set to approximately $100 \mathrm{ml} / \mathrm{s}$ (12.5 SCFH) of technical-grade methane, producing a heat flux of $3.2 \mathrm{~W} / \mathrm{cm}^{2} \pm 0.2 \mathrm{~W} / \mathrm{cm}^{2}$ from a total gas flow of $200 \mathrm{ml} / \mathrm{s} \pm 10 \mathrm{ml} / \mathrm{s}$ (25 SCFH $\pm 1.3 \mathrm{SCFH}$ ) that resulted in an energy release of $7 \mathrm{~kJ} / \mathrm{s}$. The reason for having two specimens face each other was to simulate the reinforcement that would occur in a worst-case fire.

Table 5. Specifications of cable-jacket material used at LLNL.

\begin{tabular}{|c|c|c|c|c|c|c|c|c|c|}
\hline Cable type & $\begin{array}{l}\text { Jacket/ } \\
\text { dielectric } \\
\text { materials }\end{array}$ & $\begin{array}{c}\text { Jacket } \\
\text { thickness } \\
\text { (mm) }\end{array}$ & o.d. & $\begin{array}{c}\text { Mass of } \\
\text { jacket } \\
\text { (g/cm) }\end{array}$ & $\begin{array}{l}\text { Mass of } \\
\text { dielectric } \\
\text { (g/cm) }\end{array}$ & $\begin{array}{c}\text { Total cable } \\
\text { mass } \\
(\mathrm{kg} / \mathrm{m})\end{array}$ & $\begin{array}{l}\text { Number of } \\
\text { conductors }\end{array}$ & $\begin{array}{l}\text { Conductor(s) } \\
\text { size } \\
\text { (mm) }\end{array}$ & $\begin{array}{l}\text { o Insulation } \\
\text { material }\end{array}$ \\
\hline RG 213 A/U & PVC/P.E. & 1 & 10 & 0.369 & - & 1.57 & 1 & - & 23.5 \\
\hline RG 59 B/U & PVC/P.E. & 1.02 & 6 & 0.22 & 0.0925 & 0.56 & 1 & - & 56 \\
\hline RG $58 \mathrm{C} / \mathrm{U}$ & PVC/P.E. & 0.14 & 4.95 & 0.14 & 0.05 & 0.38 & 1 & 0.9 & 52 \\
\hline Telephone cable & PVC/P.E. & 0.3 & 7.62 & 0.561 & - & 4.37 & 4 & - & 56.6 \\
\hline Welding cable AWG 6 & Neoprene & 2.54 & 10.24 & 0.68 & - & 1.94 & 1 & 5.3 & 36 \\
\hline Welding AWG 4/0 & $\begin{array}{l}\text { Neoprene/ } \\
\text { rubber }\end{array}$ & 3.5 & 23 & 4.195 & - & 14 & 1 & 14 & 29.96 \\
\hline Power cord & $\begin{array}{c}\text { Neoprene/ } \\
\text { Neoprene }\end{array}$ & - & 15.2 & 0.135 & $\begin{array}{c}\text { conductor } \\
\text { jacket } \\
0.085\end{array}$ & 0.315 & 4 & - & 72 \\
\hline Test product & $\begin{array}{c}\text { Rubber/ } \\
\text { rubber }\end{array}$ & 2 & 4.75 & 0.13 & - & 0.20 & 1 & - & 65 \\
\hline Welding $2 / 0$ & $\begin{array}{c}\text { Rubber/ } \\
\text { rubber }\end{array}$ & 2.7 & 19.05 & 1.22 & - & 7.85 & 1 & 3325 strands & 20.9 \\
\hline Welding AWG 2 & $\begin{array}{l}\text { Rubber/ } \\
\text { rubber }\end{array}$ & 0.3 & 14.2 & 1.07 & - & 4.14 & 1 & 1666 strands & 25.8 \\
\hline Audio cable & $\begin{array}{c}\text { Rubber/ } \\
\text { rubber }\end{array}$ & 0.26 & 1.1 & 0.29 & - & 0.78 & 3 & - & 37 \\
\hline
\end{tabular}



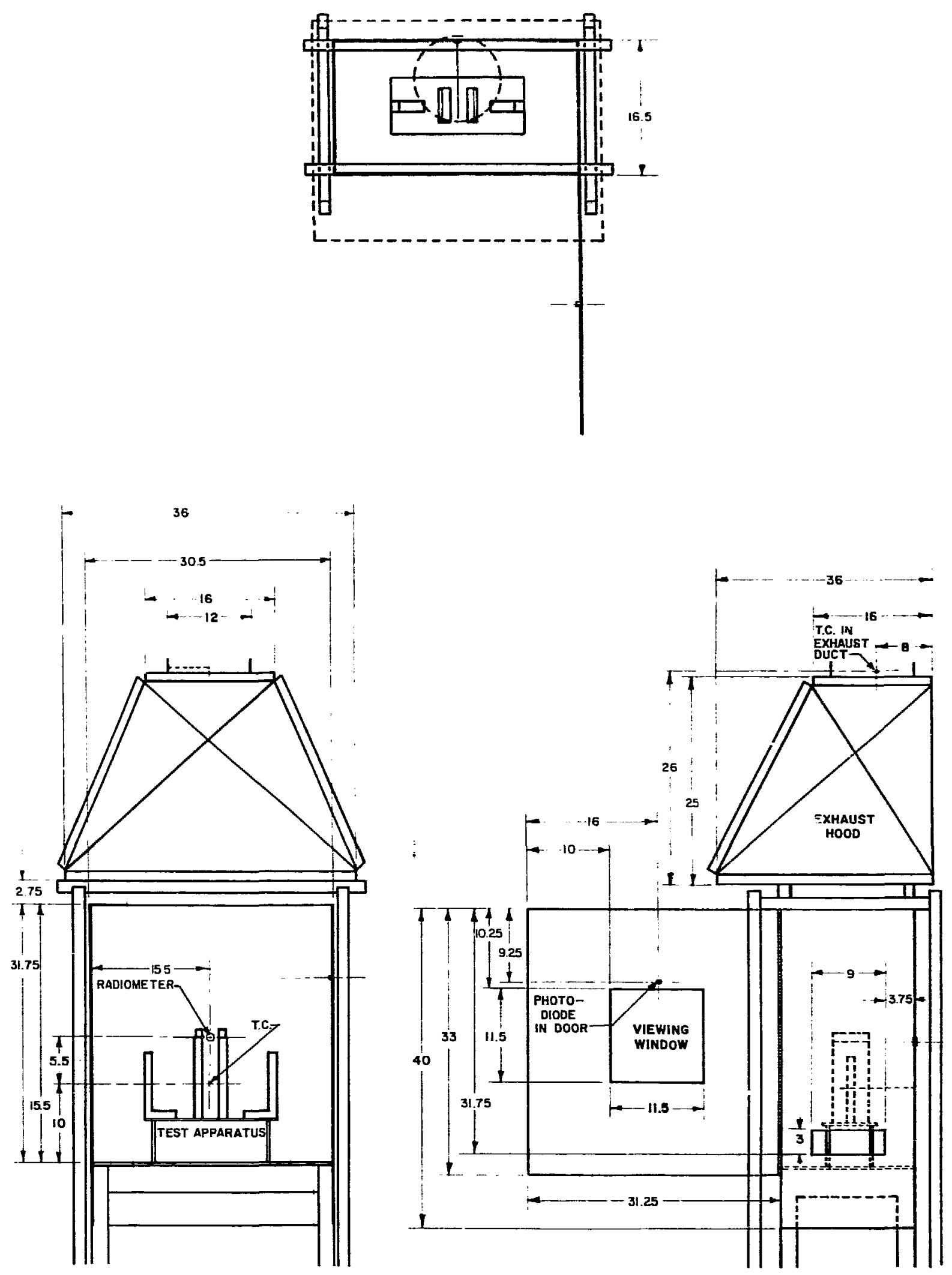

Figure 5. Schematic of ease-of-ignition apparatus. 
The ignition time is indicated by the time at which a flame attachment on a specimen surface is observed and by the time when the specimens begin to contribute a significant quantity of fuel, as :idicated by a rise in voltage of a thermopile. The thermopile con:ists of a bank of thermocouples located $6.4 \mathrm{~mm}$ above the top edge of each specimen and $6.4 \mathrm{~mm}$ out from the plane of their surfaces."

\section{Test Specimens}

We tested eight rectangular cable array samples, $140 \mathrm{~mm}$ wide and $152 \mathrm{~mm}$ high. Two arrays were required for each test, and four replicate tests were conducted. The specimen holders gripped the cable samples at their ends and provided sufficient tension to prevent large deformation of the individual cables due to heating, which ensured reasonable reproducibility among samples.
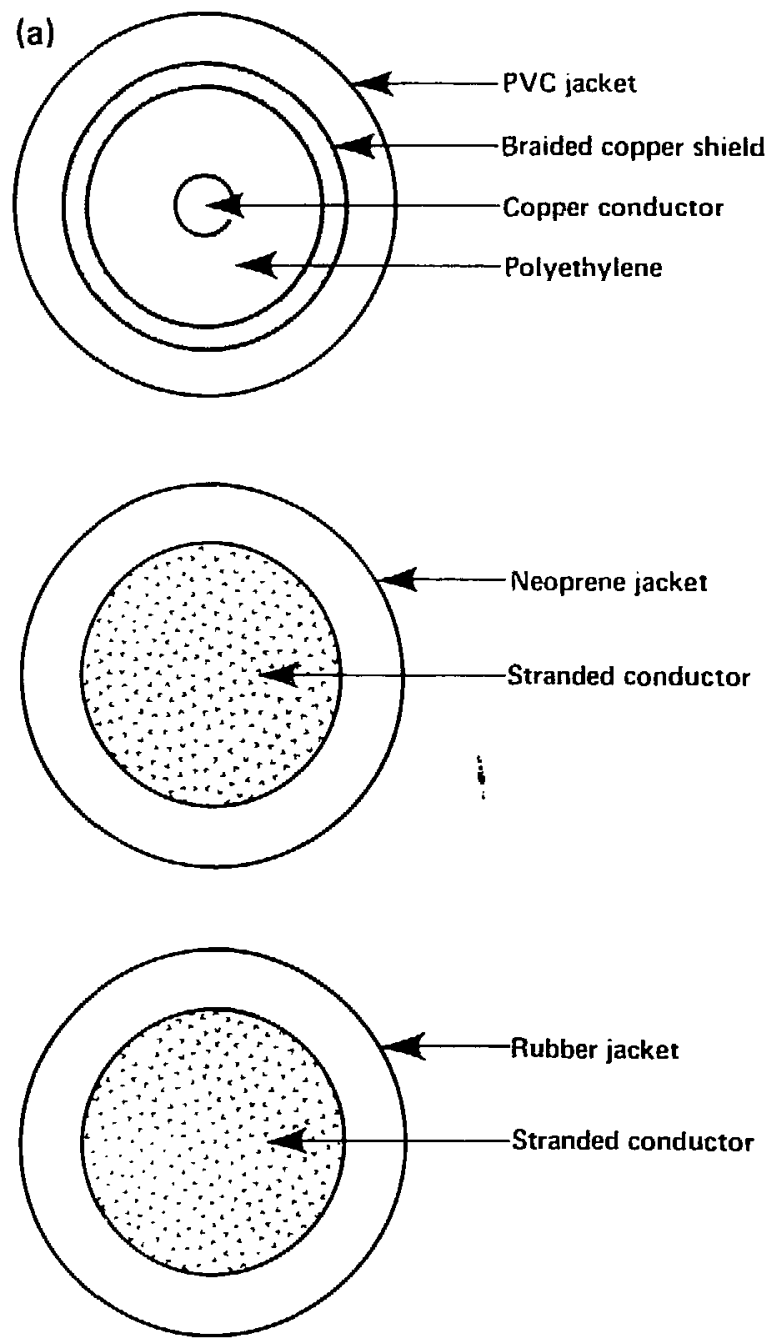

We intended to establish a correlation between a cable's physical characteristics and its time to fuel contribution. In our analysis, the physical characteristics considered were the outside diameter, the total mass per centimeter, and the percentage of insulating material. These properties were then plotted against their respective times to fuel contribution. Further analysis was conducted to determine the change in performance from a single conductor to a multiconductor. PVC, Neoprene, and rubber were analyzed separately, and all conclusions were based on a comparison of the performance of the three materials.

\section{PVC Results}

As shown in Fig.6, the PVC cables tested, with the exception of the multiconductor, were
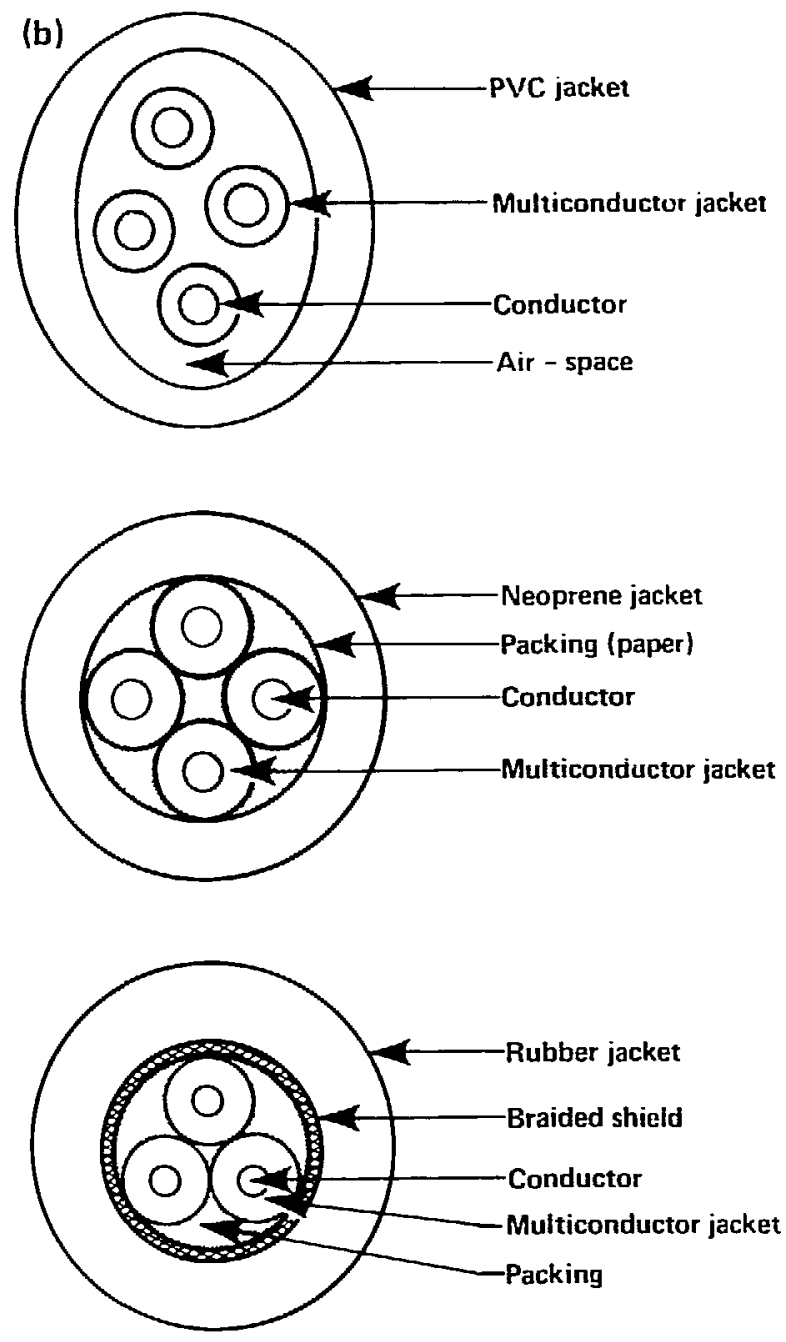

Figure 6. Cross sections of (a) single conductor cables and (b) multiconductor cables. 
coaxial types using polyethylene as the dielectric material. Of the three insulating materials tested, PVC was the only one to exhibit a near linear relationship betwet $n$ its physical characteristics and time to ignition.

The data display'ed in Figs. 7a through 7c indicate the following relationships:

- Decreasing the outside diameter reduces the ignition time (Fig. 7a).

- Although it is not a linear relationship, it appears that decreasing the mass also reduces the ignition time (Fig. $7 \mathrm{~b}$ ).
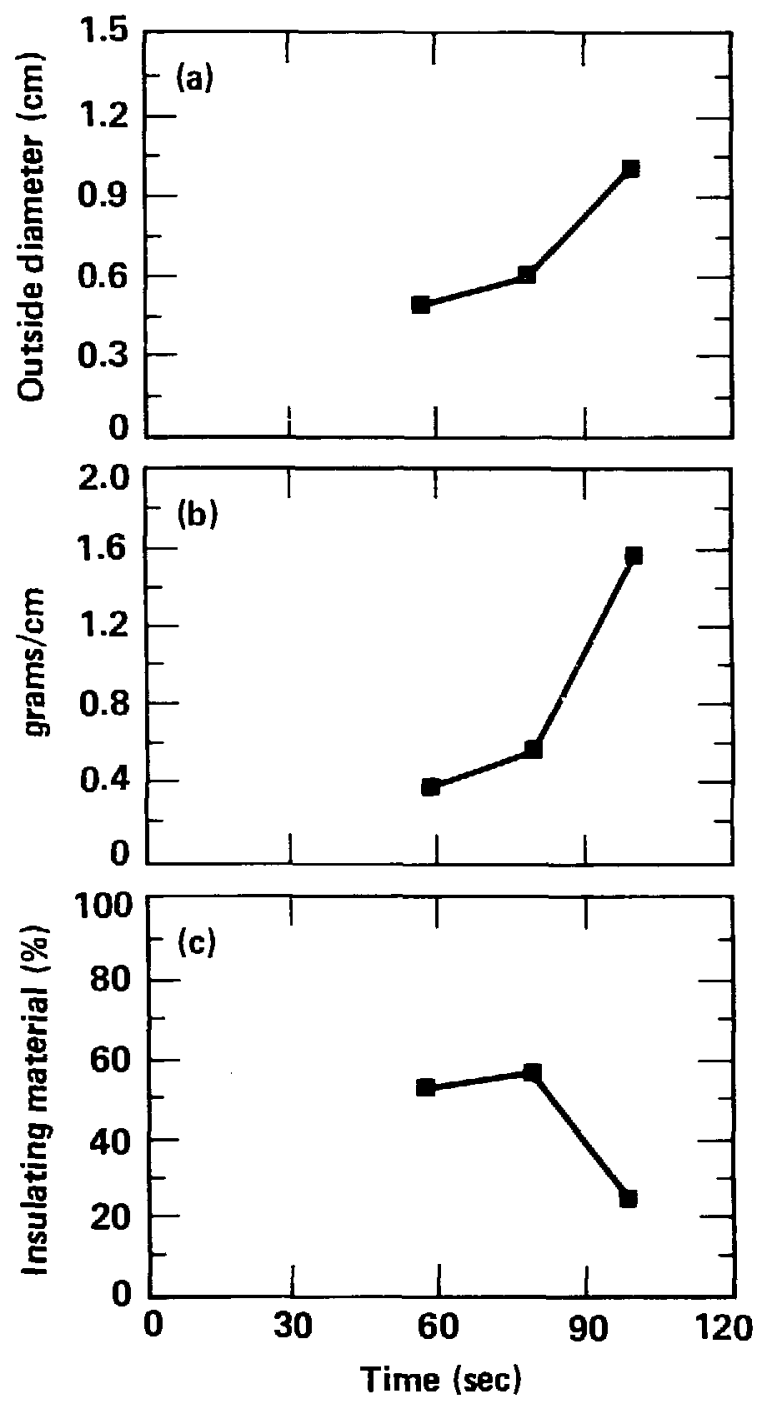

Figure 7. Times to fuel contribution for PVC as a function of (a) decrease in outside diameter, (b) decrease in mass, and (c) percentage of insulating material and the time to ignition.
- No correlation exis; ; between the percentage of insulating material and the ignition time (Fig. 7c).

These preliminary findings follow heat transfer principles. In order for cable insulations to ignite, they must be heated to their ignition temperature. The greater the mass, the more energy, or, in this case, the more time is needed to bring the jacket material to its critical temperature.

Conversely, reducing the mass reduces the heating time. The testing of a multiconductor seemed to confirm the physical characteristicsignition time relationship. The four-conductor telephone cable was loosely wrapped with a PVC jacket that resulted in a substantial airspace between the outer jacket and the conductors. This elliptical cable had a major axis diameter of $0.76 \mathrm{~cm}$ and an ignition time of $11 \mathrm{~s}$. By comnarison, the RG $59 \mathrm{~B} / \mathrm{U}$ cable (single conductor) with an outside diameter of $0.6 \mathrm{~cm}$ had an ignition time of $79 \mathrm{~s}$. The greatly reduced ignition time for the multiconductor cable can be directly atributed to the airspace that allows the outer jacket material to heat up rapidly (i.e., only the mass of the jacket absorbs the heat as opposed to having the jacket and insulator in the coaxial heat up). It appears that we may be able to roughly predict the ignition times of PVC-jacketed coaxial cables with respect to the scale of the Ease-of-lgnition apparatus.

\section{Neoprene Results}

Due to limited availability, only three of the chosen four Neoprene-insulated cables were tested, and one of these was a multiconductor. So, since multiconductors are not plotted, we had to use only two data points. We can draw no clear conclusion. However, the two data points shown in Figs. 8a and 8b infer Neoprene's time-to-fuelcontribution is independent of the cables' physical properties. Both plots show that cables with vastly different outside diameters and masses had almost identical ignition times. Yet, like PVC, the Neoprene multiconductor of larger diameter displayed a fuel-contribution time of nearly half (ignited twice as fast) that of the single condustor, 47 and $85 \mathrm{~s}$, respectively. This indicates that, in our choice of single-conductor cable sizes, we have exceeded a size threshold where the conductor absorbs most of the thermal energy. This makes the ignition time solely dependent on the chemiral composition and the density of the jacket. 


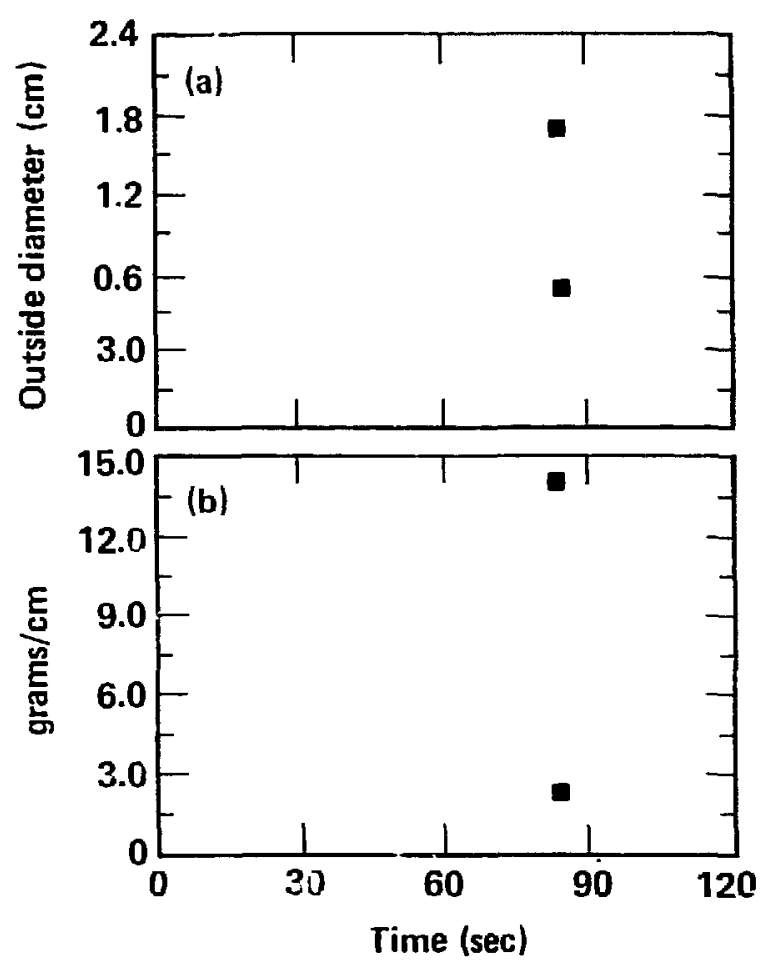

Figure 8. Times to fuel contribution to Neoprene showing (a) the outside diameter and (b) decreasing mass.

Again, the energy dissipation in the multiconductor is not as pronounced as in the single conductor. Further experiments will have to substantiate this hypothesis.

\section{Rubber Results}

Preliminary examination of the rubberinsulated cables shows no correlation between physical characteristics and the time-to-fuelcontribution (see Figs. $9 a$ and $9 b$ ). The results show that the AWG 2 cable with an outside diameter of $1.37 \mathrm{~cm}$ had an average time to ignition of $146 \mathrm{~s}$, while the larger AWG $2 / 0$ cable with an outside diameter of $1.9 \mathrm{~cm}$ had an average ignition time of $120 \mathrm{~s}$. Our third data point was a $0.495-\mathrm{cm}$ wire with a short time-to-fuel-contribution of $67 \mathrm{~s}$. And, like the previous cables, the rubber multiconductor indicated a reduced ignition time of $69 \mathrm{~s}$.
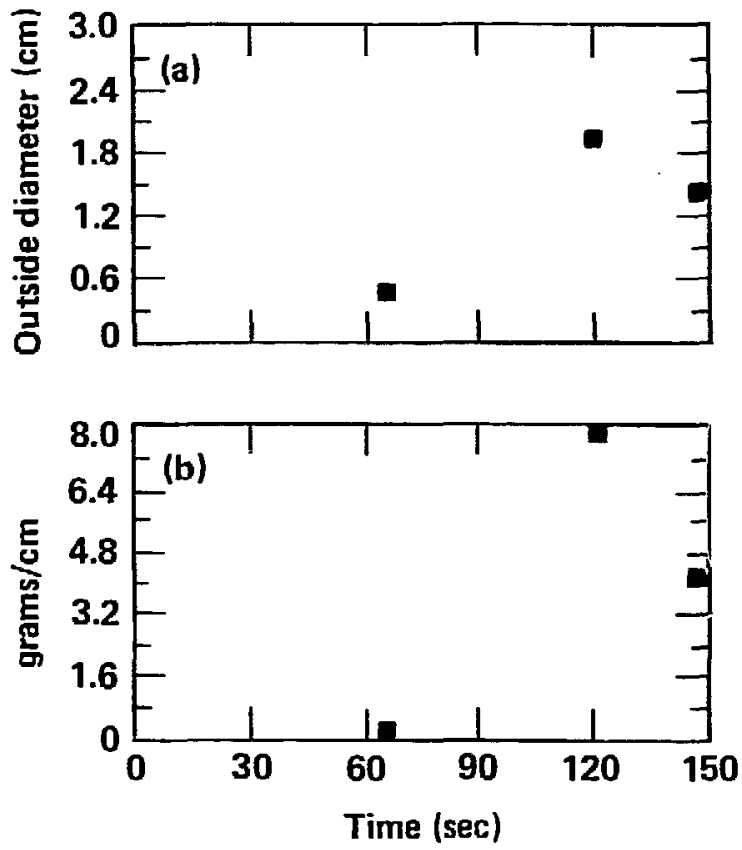

Figure 9. Rubber test result showing (a) increasing outside diameter and (b) decreasing cable mass.

\section{Conclusions}

The results from this test series show that the Ease-of-lgnition apparatus in its present form cannot be used to accurately discriminate between materials with similar flammability characteristics. A major problem is that fire exposure fluctuates over a statistically significant range because it is a diffusion flame. Since times-to-fuel-contribution, in most cases, differ by only seconds, nonuniform exposure produces scattered results. Furthermore, the ignition time is calculated on the average of four tests. If one or more results are at extreme range, the average ignition time can be very inaccurate. Although great pains were taken to ensure uniformity among specimens before and during testing, it is highly probable that individual cables deformed during the fire. This would change the amount of cable surface area exposed to the flame, which would alter its ignition time. 
We believe the combination of the above variables is significant enough to cause the random results obtained from the rubber-jacketed cable tests; the larger and more massive AWG 2/0 cable had a time-to-fuel-contribution which was $26 \mathrm{~s}$ less than the smaller AWG 2 cable. The following ignition times for the two cable types illustrates the wide variation in times:

\begin{tabular}{cccc} 
Burn & & AWG 2 & AWG 2/0 \\
\hline 1 & & $135.0 \mathrm{~s}$ & $95 \mathrm{~s}$ \\
2 & & $119.0 \mathrm{~s}$ & $145 \mathrm{~s}$ \\
3 & $172.0 \mathrm{~s}$ & $105 \mathrm{~s}$ \\
4 & $159.4 \mathrm{~s}$ & $135 \mathrm{~s}$
\end{tabular}

It can be seen that both sets of data have a spread of about $50 \mathrm{~s}$ from the shortest to longest ignition time. A possible improvement is to substitute a radiant panel (the same size as a specimen) for one of the specimens and eliminate all the existing burner ports except for one under the sample to serve as a pilot flame. The radiant panel would provide a uniform and steady thermal flux on the specimen and should provide more reproducible results.

Consequently, our study can only provide performance trends. The study does indicate that the three major physical characteristics that govern a cable's ignition time are the mass per unit length, the outside diameter, and the ratio between conductor and insulator. It appears that cables with a conductor diameter of approximately $0.8 \mathrm{~cm}$ and greater, and a ratio of conductor to outside diameter of $60 \%$ or more, will have ignition times dependent primarily on the chemical composition of the jacket material. Thus, if the conductor's mass dominates the cable composition, it is as if the jacket material is attached to an infinitely conductive slab. Cables containing smaller conductor sizes will probably perform according to relationships derived from a cable's chemical composition, physical make-up, and physical dimensions, as was indicated by the PVC coaxials we tested in this study. Similarly, PVC four-wire multiconductors would perform to one relationship, triaxials to another, and so on.

\section{Fire Chemistry: Thermal Degradation of Cable and Wire Insulations}

In moderate-temperature py'roly'sis of various wire and cable insulations, the insulations form detectable amounts of light hydrocarbons in the very early degradation sitage.' Our GC/MS analyses of the liquid pyrolyzates from these insulations show no unique components of specific insulations that can help in choosing fire-resistant cables. The data, however, can be used to isolate those insulations that incorporate flammable plasticizers; such plasticizers enhance the insulations' flammability so that flame retardants should be incorporated if the plasticizers are used in the insulations.

We have found that the production of acidic components is enhanced by higher heating rates, but, higher heating rates do not increase total acid production. The presence of acid acceptors (e.g., $\mathrm{ZnO}, \mathrm{HgO}, \mathrm{Sb}_{2} \mathrm{O}_{3}$, and $\mathrm{CaCO}_{3}$ ) will influence how much acid is released into the environment. This year, we extended these kinds of detailed studies to Teflon and Kynar wire insulations. And, we added more GC/MS measurements on insulations reported in last year's report, specifically hightemperature pyrolysis and usage of additional GC capillary columns to resolve pyrolyzates obtained at medium-temperature pyrolysis.

\section{Experimental Procedure}

Experiments involving Teflon and Kynar wire insulations and their corresponding virgin polymers consisted of thermogravimetric analysis (TGA), differential scanning analysis (DSCA), and GC/MS of their pyrolyzates on four chromatographic columns. Teflon and wire-insulation TGA was done in air at heating rates of $10,20,40,80$. and $160^{\circ} \mathrm{C} / \mathrm{min}$ from ambient temperature to $900^{\circ} \mathrm{C}$. As reported previously, we monitored the samples' weights and the generation of acidic components as a function of temperature. As before, the acidic components and other thermal degradation products were directed to a container filled with $200 \mathrm{ml}$ of distilled water buffered to a $\mathrm{pH}$ of $6.8-9.8$. The gaseous solution was gently stirred with a magnetic stirrer to achieve uniform mixing and the change in $\mathrm{pH}$ was measured with a pencil-sized $\mathrm{pH}$ reference electrode and recorded on a multichannel recorder.

DSCA was performed on a DuPont-900 differential scanning calorimeter using a standard cell. Our samples weighed between 5 and $10 \mathrm{mg}$ and all were heated in air at $20^{\circ} \mathrm{C} / \mathrm{min}$. The rest of the testing followed the procedure reporied in last year's report.' 


\section{Experimental Results}

\section{Teflon}

Polytetrafluoroethylene (Teflon), used in smallsignal wire insulations, is one of the most stable addition polymers, owing to the strength of the $C-F$ bond and the shielding effect of the highly electronegative fluorine atoms. Reaction involves random-chain scission followed by depolymerization and chain termination by dispropurtionation, ${ }^{7.8 .9}$ although it has been suggested that, instead of an unzipping mechanism, $\mathrm{CF}_{2}$ fragments are eliminated which subsequently combine in the gas phase to give tetrafluoroethylene.

Figure 10 shows our TGA results of Teflon-7, Teflon-107, and virg,in polytetrafluoroethylene. Essentially, there is one degradation phase that leaves no residue at the end of pyrolysis. Of the three samples studied, virgin polytetrafluoroethylene degrades at the lowest rate and requires the lowest temperature for the onset of the main degradation phase. The main pyrolysis phase starts at $500^{\circ} \mathrm{C}$ for virgin polytetrafluoroethylene, at $535^{\circ} \mathrm{C}$ for Teflon-7, and at $540^{\circ} \mathrm{C}$ for Teflon107 . The main degradation phase is preceded by an induction phase that s!arts at $445^{\circ} \mathrm{C}$ for virgin polytetrafluoroethylene, at $430^{\circ} \mathrm{C}$ for Teflon-7, and at $450^{\circ} \mathrm{C}$ for Teflon- 107.

The effect of heating rates on the degradation of the two Teflon insulationc and virgin polytetrafluoroethylene is suminarized in Table 6. As expected, higher heating rates increase the degradation rates of all three samples. The higher. heating rates, however, do not change the temperaure that is responsible for the onset of the main degradation phase of the virgin poly'etrafluoroethylene and the effect is inconsisten $i$ on the main pyrolysis phase of both Teflon-7 and Teflon-107. We also found that heating rates of $40^{\circ} \mathrm{C} / \mathrm{min}$ and higher decrease the temperature leading to the induction phase of Teflon-107. However, the induction phase of Teflon-7 remains unaffected until it

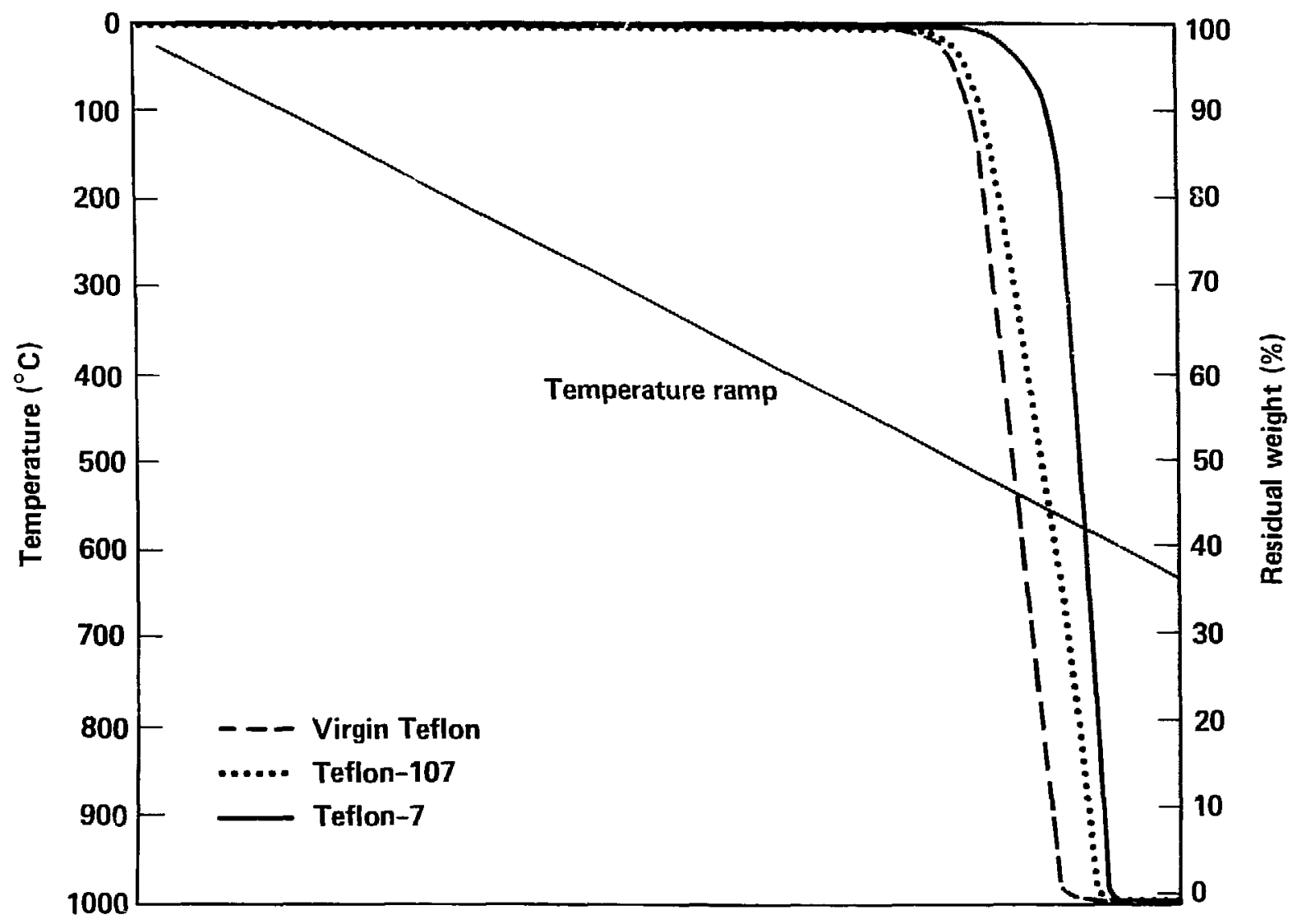

Figure 10. Thermograms of Teflon insulations heated in air at $20^{\circ} \mathrm{C} / \mathrm{min}$. The diagonal temperature ramp provides a way to correlate weight loss and temperature, where the rampline defines the apex of a right angle between discrete points on the residual weight curve and temperature scale. 
Table 6. The effect of heating rate on thermal degradation of Teflon.

\begin{tabular}{|c|c|c|c|c|c|}
\hline Sample & $\begin{array}{l}\text { Heating } \\
\text { rate } \\
\left({ }^{\circ} \mathrm{C} / \mathrm{min}\right)\end{array}$ & $\begin{array}{c}\text { Onset of } \\
\text { induction phase } \\
\left({ }^{\circ} \mathrm{C}\right)\end{array}$ & $\begin{array}{l}\text { Onset of } \\
\text { main phase } \\
\left({ }^{\circ} \mathrm{C}\right)\end{array}$ & $\begin{array}{c}\text { Degradation } \\
\text { rate } \\
(\% / \text { min })\end{array}$ & $\begin{array}{l}\text { Residual wt. } \\
\text { at end of } \\
\text { pyrolysis (\%) }\end{array}$ \\
\hline Virgin & 10 & $\$ 30$ & 500 & 22 & $\mathbf{0}$ \\
\hline \multirow[t]{4}{*}{ polytetrafluoroethylene } & 20 & 445 & 500 & 33 & $\mathbf{0}$ \\
\hline & 40 & 445 & 500 & 55 & $\mathbf{0}$ \\
\hline & 80 & 445 & 500 & 90 & $\mathbf{0}$ \\
\hline & 160 & 450 & 500 & $>100$ & $\mathbf{0}$ \\
\hline \multirow[t]{5}{*}{ Teflon-7 } & 10 & 430 & 495 & 25 & $\mathbf{0}$ \\
\hline & 20 & 430 & 535 & 50 & $\mathbf{0}$ \\
\hline & 40 & 430 & 500 & 73 & $\mathbf{0}$ \\
\hline & 80 & 485 & 548 & $>100$ & 0 \\
\hline & 160 & 230 & 550 & $>100$ & $\mathbf{0}$ \\
\hline \multirow[t]{5}{*}{ Teflon-107 } & 10 & 450 & 545 & 29 & $\mathbf{0}$ \\
\hline & 20 & 450 & 540 & 43 & 0 \\
\hline & 40 & 425 & 545 & 82 & $\mathbf{0}$ \\
\hline & 80 & 370 & 540 & $>100$ & 0 \\
\hline & 160 & 200 & 490 & $>100$ & 0 \\
\hline
\end{tabular}

is exposed to a heating rate of $160^{\circ} \mathrm{C} / \mathrm{min}$. Higher heating rates do not lower the temperature responsible for the induction phase of virgin polytetrafluoroethylene.

Figure 11 shows the DSCA of virgin polytetrafluorcethylene in air; the endotherm began at $338^{\circ} \mathrm{C}$, which we attribute to melting and an exotherm began at $445^{\circ} \mathrm{C}$ which is at the start of the induction period or very slow decomposition phase. Teflon-7 showed an endotherm starting at $317^{\circ} \mathrm{C}$ and an exotherm starting $460^{\circ} \mathrm{C}$, which is the beginning of the induction period. Teflon-107 showed an endotherm at $322^{\circ} \mathrm{C}$ and a beginning of an exotherm at $460^{\circ} \mathrm{C}$, again due to initiation of the decomposition phase.

The gaseous-products analysis shows the presence of $\mathrm{HF}$ which we think is formed as a result of the following reaction:

$2 \mathrm{COF}_{2}+2 \mathrm{H}_{2} \mathrm{O} \cdot \mathrm{CO}_{2}+4 \mathrm{HF}$.

Other gaseous secondary products formed after dehalogenation were found to be low-molecularweight hydrocarbons such as methane, ethylene, acetylene, ethane, propane, propyne, isobutane, n-butane, 1-butene, isobutylene, cis-2-butene, trans-2-butene, and pentane. These hydrocarbons are produced in large quantities from virgin polytetrafluoroethylene, but not from Teflon-107 and Teflon-7: Of the latter two insulations,

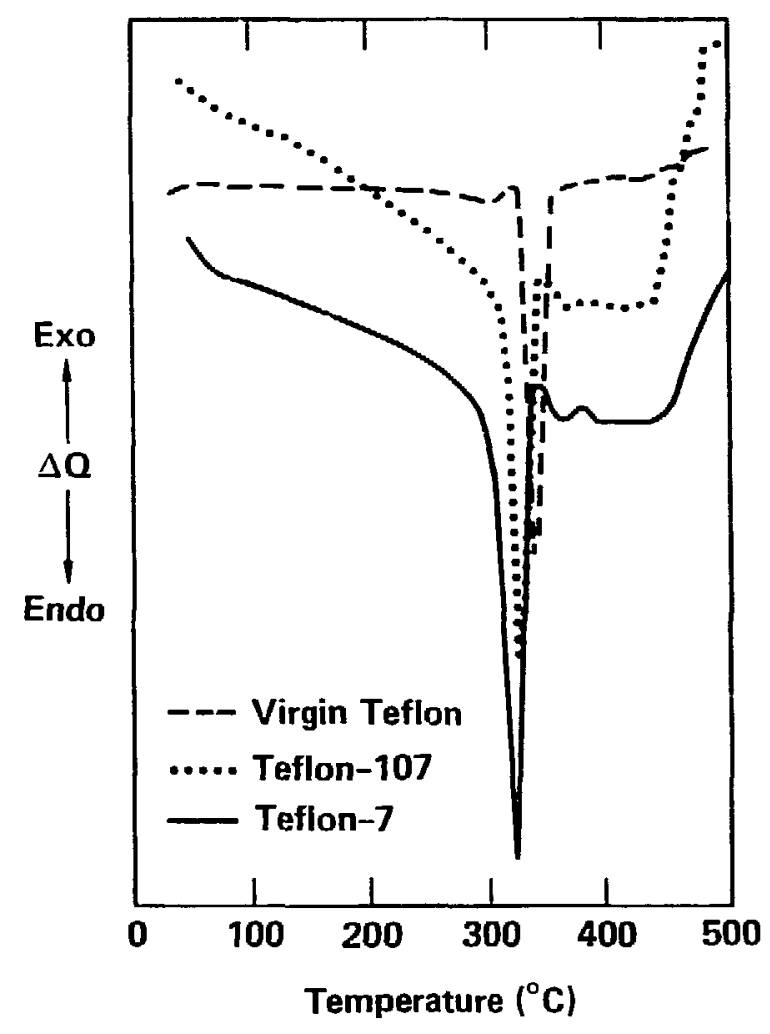

Figure 11. DSCA of Teflon insulations heated in air at $20^{\circ} \mathrm{C} / \mathrm{min}$. 
Teflon-107 produces more hydrocarbons than Teflon-7. We also noticed that high-temperature pyrolysis increased the amount of the hydrocarbons in all samples. In addition, the gaseous mixture in all samples contained $\mathrm{C}_{3} \mathrm{~F}_{4}, \mathrm{C}_{3} \mathrm{~F}_{\mathrm{n}}, \mathrm{C}_{4} \mathrm{~F}_{\mathrm{h}}$, $\mathrm{C}_{2} \mathrm{~F}_{4}, \mathrm{C}_{2} \mathrm{~F}_{6}$, and $\mathrm{CF}_{4}$.

High-temperature pyrolysis of Teflon-107 led to a liquid pyrolyzate comprised mainly of trimers and tetramers of tetrafluoroethylene, hexafluorobenzene, 1,3-di-(2-xenyl)-benzene. Teflon-7's high-temperature pyrolysis resulted in liquid pyrolyzates consisting of 3,5,5-trimethyl-1hexene, diethylphthalate, butyl methyl phthalate, dioctylphthalate, methyl-2-methyl octadecanoate, 3,6-dimethyl-3-heptanol, trimers and tetramers of tetrafluoroethylene.

The liquid pyrolyzate nbtained from medium-temperature pyrolysis of tetrafluoroethylene yielded 2-H-perfluorohexane, 3,5,5trimethyl-1-hexene, tetrafluoroethylene trimer and tetrafluoroethylene tetramer, and unidentified components. Medium-temperature pyrolysis of Teflon-107 rendered a pyrolyzate comprised of 2-methyl-1-(2-methylpropylimino) propane, perfluoroheptene-1, perfluoromethyl-cyclohexane, tetrafluoromethylcyclohexane, perfluoroheptene-1, butylphthalate, and dioctylphthalate. The phthalates are decomposition products of the plasticizer used in formulation. Medium-temperature pyrolysis of Teflon-7 produced a liquid pyrolyzate consisting of 2-N-hexyl-N-methyl pyrrolidene, hutylphthalate, and dioctylphthalate.

\section{Kynar}

Kynar (polyvinylidene fluoride). also used in small-signal wire, thermally degrades primarily by dehydrofluorination with evidence of other degradative processes such as chain scission, cross-linking, cyclization and hydroperoxide formation. "The TGA of Kynar-51 and virgin polyvinylidene fluoride show that hoth have two regions of decomposition. There is the main pyrolysis region, which is due to loss of $\mathrm{HF}$, and a second region which involves decomposition of the residual cross-linked polymer chains. The main degradation region is preceded by an induction period that is probably due to activation of the weak links in the polymer.

Figure 12 contrasts the thermograms of Kynar-51 and virgin polyvinylidene fluoride

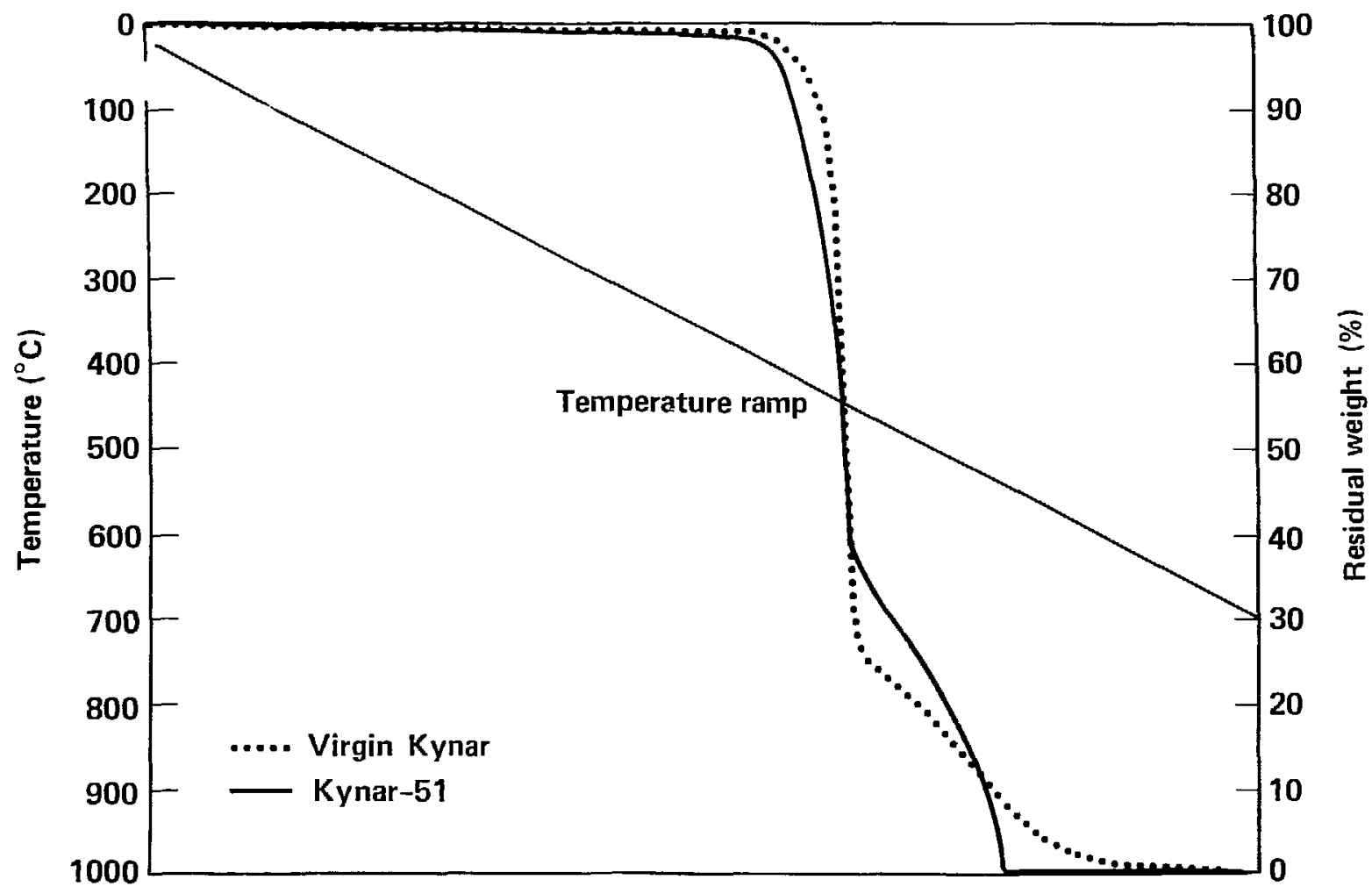

Figure 12. Thermogram of Kynar-51 and virgin Kynar heated in air at $20^{\circ} \mathrm{C} / \mathrm{min}$. See Figure 10 caption for the interpretation of the temperature rampline. 
heated in air at $20^{\circ} \mathrm{C} / \mathrm{min}$. We see that the main degradation phase for Kynar-51 shows a lower overall weight loss and a lower rate of weight loss than virgin polyvinylidene fluoride.

The effect of heating rates on the degrauation of Kynar-51 and virgin polyvinylidene fluoride is summarized in Table 7. As expected, the higher heating rates lead to higher degradation rates and therefore faster production of HF. We found that heating rates below $160^{\circ} \mathrm{C} / \mathrm{min}$ do not effect the temperature responsible for the onset of the induction phase of virgin polyvinylidene fluoride. At $160^{\circ} \mathrm{C} / \mathrm{min}$, the temperature leading to the induction phase of virgin polyvinylidene fluoride is considerably lower than that observed with the lower heating rates. The induction phase of Kynar-51 occurs at a higher temperature at higher heating rates up to a heating rate of $160^{\circ} \mathrm{C} / \mathrm{min}$, at which rate the induction phase occurs at a considerably lower temperature. The effect of heating rates is inconsistent on the main phase pyrolysis of both the Kynar-51 and the virgin polyvinylidene fluoride samples.

Figure 13 shows the DSCA results of polyvinylidene fluoride and Kynar-51. Virgin polyvinylidene fluoride shows an endotherm at $150^{\circ} \mathrm{C}$ due to the polymer melting, an endotherm at $375^{\circ} \mathrm{C}$ in the realm of the induction phase, an exotherm at $442^{\circ} \mathrm{C}$ in the beginning of the dehalogenation region, and an exotherm at $455^{\circ} \mathrm{C}$ where the degradation of the residual cross-linked polyol begins. Kynar -51 shows an endotherm at $149^{\circ} \mathrm{C}$ due to melting, an exotherm at $390^{\circ} \mathrm{C}$ due to the beginning of dehalogenation region, and an exotherm at $445^{\circ} \mathrm{C}$ at the beginning of the degradation of the residual polymer.
$\mathrm{HF}$ is the dominant gas evolved from degrading virgin polyvinylidene fluoride and Kynar-51 at both medium and high temperatures. Other gases formed from virgin polyvinylidene fluoride and Kynar-51 at both the medium- and high-temperature pyrolysis are methane. ethylene, acetylene, ethane, propane, propylene, propyne, isobutane,

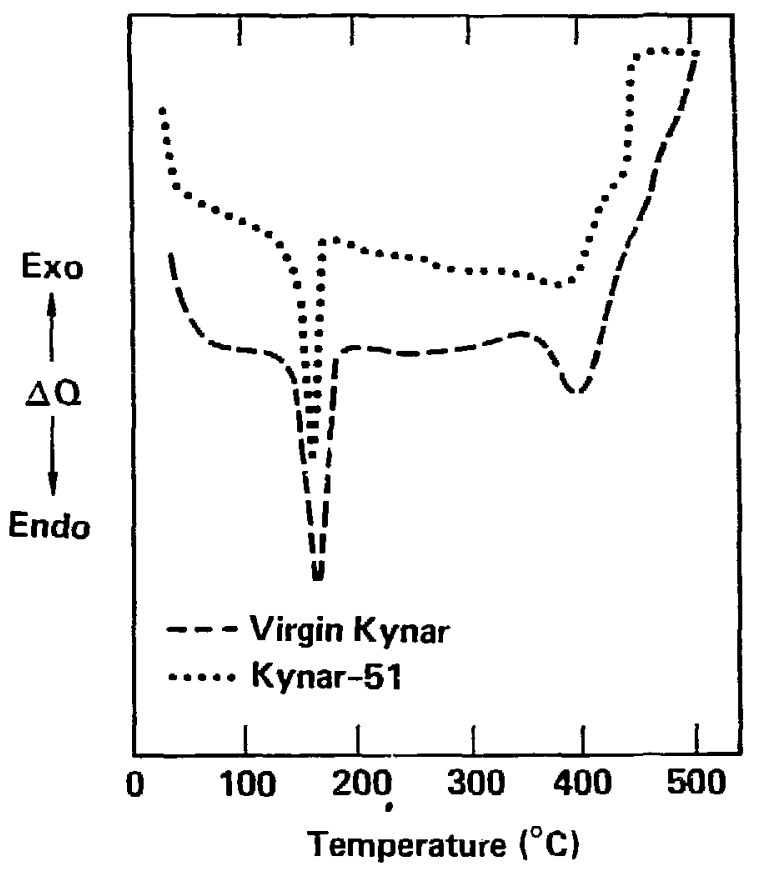

Figure 13. DSCAs of Kynar insulations heated in air at $20^{\circ} \mathrm{C} / \mathrm{min}$.

Table 7. The effect of heating rate on thermal degradation of Kynar.

\begin{tabular}{|c|c|c|c|c|c|c|}
\hline Sample & $\begin{array}{l}\text { Heating } \\
\text { rate } \\
\left({ }^{\circ} \mathrm{C} / \mathrm{min}\right)\end{array}$ & $\begin{array}{l}\text { Onset of } \\
\text { induction } \\
\text { phase } \\
\left({ }^{\circ} \mathrm{C}\right)\end{array}$ & $\begin{array}{c}\text { Onset of } \\
\text { main phase } \\
\text { (linear regiun) } \\
\left.\text { ( }{ }^{\circ} \mathrm{C}\right)\end{array}$ & $\begin{array}{l}\text { Degradation } \\
\text { rate in } \\
\text { main phase } \\
(\% / \text { min })\end{array}$ & $\begin{array}{c}\text { Onset of } \\
\text { phase-II } \\
\text { (linear region) } \\
\left({ }^{\circ} \mathrm{C}\right)\end{array}$ & $\begin{array}{l}\text { Residual wt. } \\
\text { at end of } \\
\text { pyrolysis } \\
\text { (\%) }\end{array}$ \\
\hline Virgin & 10 & 330 & 420 & 24 & 470 & 0 \\
\hline \multirow[t]{4}{*}{ Polyvinylidenefluoride } & 20 & 320 & 445 & 88 & 501 & 0.5 \\
\hline & 40 & 335 & 395 & 80 & 475 & a \\
\hline & 80 & 330 & 380 & $>100$ & 460 & 0 \\
\hline & 160 & 150 & 400 & $>100$ & 500 & $\mathbf{0}$ \\
\hline \multirow[t]{5}{*}{ Kynar } & 10 & 90 & 422 & 35 & 473 & $\mathbf{0}$ \\
\hline & 20 & 165 & 420 & 39 & 500 & 0 \\
\hline & 40 & 245 & 420 & $>100$ & 500 & 1.0 \\
\hline & 80 & 300 & 430 & $>100$ & 525 & 1.75 \\
\hline & 160 & 170 & 410 & $>100$ & 530 & 1.75 \\
\hline
\end{tabular}


n-butane, 1-butene, isobutylene, trans-2-butene, ethylacetylene, 1.3-butadiene, and pentane.

The liquid pyrolyzate from virgin polyvinylidene fluoride heated at medium temperature vielded a highly complex mixture, consisting of at least 50 compounds, of which only 5 components were identified. $W$ : identified 1-H-purfluorohexane, ethylacetate, 1,1,1,3,3-pentafluoropropene, 2-methoxy diphenyl ether, and 1,1,1-trifluoroethane. High-ten.perature pyrolysis also yielded a complex mixture, must of which was not identified. $r_{L l}$ which matched those found in the medium-temperature pyrolyzate.

The liquid pvrolyzate from Kynar-51, generated at me.jium temperature, rendered the following compounds: 1-H-perfluorohexane, borneol. di(trifluoromethyl) furan, methylphenylacetate, farnesol, n-butyl-o-phthalate, 4-carboxybenzophenone, and other uniclentified components. High-temperature pyrolysis yielded 3-bromo-3,3difluoro-1-propene, tetrafluoro-2-methylpentane, 4-methoxy-diphenyl ether, 2(trifluoromethyl) propene, 1,1,2,2-tetrafluoropropane, hexafluorotert-butyl trifluoroacetate, $1,1,2,2,3,3,4,4$ octafluoropentane, and a number of unknown compounds.

\section{Additional GC/MS Results on FY 82 Pyrolyzates}

\section{PVC}

Table 8 lists additicnal degradation products identified this year for the FY 82 materials tested previously. The products were generated at medium temperature or at the temperature responsible for the dehalogenation region, and were separated on an SE-54 fused-silica capillary column.

High-temperature pyrolysis of virgin PVC, PVC-3, PVC-78, and PVC-104 produced high concentrations of ethylene, acetylene, ethane, propane, propylene, propyne, n-butane, 1-butene, isobutylene, and ethylacetylene. The amount of the gaseous hydrocarbons in all of the PVC samples was considerably higher at this temperature than those formed at medium temperature.

Table 9 lists the constituents of the liquid pyrolyzates generated at high temperature separated on both the Carbowax-20M and the SE-54 columns. Both columns indicated that the liquid pyrolyzate consists primarily of aromatic components which are largely the secondary decomposition products of PVC. In addition to the aromatic compounds formed directly from the decomposing plastics, degradition products are also formed fron the plasticizers such as phthalic anhydride, di-(2-ethylhexyl) phthalate, phthalic acid, dibutyl phthalare, and stearic acid.

\section{Rubber}

High-temperature pyrolysis of Neoprene-Cu7. -84 , and $-\$ 35$ resulted in a substantial increase in the production of the the:e hydrocarbons: ethylene, acetylene, ethane, propane, propylene, propyne, $\mathbf{n}$-butane, 1-butene, isobutylene, cis-2. butene, trans-2-butene, ethylacetylene, pentane, and a number of other unidentified hydrocarbons.

GC/MS results of the liquid pyrolyzates generated from Neoprene are listed in Table 10. The constituents are mainly chlorinated and nonchlorinated aromatics, originating from the degrading plastics, as well as phthalates which are degradation products of the plasticizers used in the formulations. The main difference between thuse high-temperature degradation products and those from medium-temperature fyrolysis is a reduction in the quantity of liquid pyrolyzates, particularly in the lower-molecular-weight compounds.

The SE-54 results at medium temperature for rubber-134 and -138 show mainly higher molecular weight aliphatic hydrocarbons, aliphatic alcohols, naphthalene, benzoic, and phthalic acids for rubber-134; those from rubber-138 are predominantly aromatic.

High-temperature pyrolysis of rubber-12, rubber-134, rubber-138, nubber-1132, and rubber1138 again produced large amounts of the $C_{1}-C_{5}$ hydrocarbons: methane, ethylene, acetylene, propane, propylene, propyne, isobutane, n-butane, 1-butene, isobutylere, tráns-2-butene, 1,3-butadiene, and pentane.

The constituents of the liquid pyrolyzates from the rubbers are aromatic esters, aldehydes, ketones, and variously substituted benzenes (Table 11). In addition, degradation products from the plasticizers include such as palmitic acid, dioctylphthalate, n-amylphthalate, phthalic anhydride, butylmethylphthalate, and n-butyl-ophthalate. The overall effect of the high-temperature pyrolysis on the liquid degradations products is that the pyrolyzate formed at high temperature is composed mainly of aromatic componens as opposed to the low-temperature pyrolyzate which is comprised of both aliphatic and aromatic constituents.

\section{Polyèthylene}

High-temperature pyrolysis of polyethylene yielded a considerable increase from mediumlemperature Pyrolysis in the production of ethylene, acetylene, ethane, propane, propylene and 
Table 8. Newly identified degradiation products from pyrolysis of PVC a generated at medium temperature and separated on SE-54 fused-sileca capillary columr.

\begin{tabular}{|c|c|c|c|}
\hline$\underset{(\mathrm{min})}{\mathrm{T}_{\mathrm{R}}{ }^{+}}$ & Virgin PVC & $\underset{(\min )}{T_{R}}$ & PVC-3 \\
\hline 3.0 & m-xylene & 3.9 & pinocamphene \\
\hline 3.7 & n-propylberzene & 4.0 & ethyltoluene \\
\hline 44 & 2,2,5-trimethylhexane & 4.5 & propenylbenzene \\
\hline 4.7 & 2,2,3,3-tetramethylpentane & & \\
\hline 4.8 & methylstyrene & & \\
\hline 5.0 & 2,2,5,5-trimethylhexane & & \\
\hline 5.1 & 2,2,4-trimethylheptane & & \\
\hline 9.5 & 3-methylindane & & \\
\hline 12.3 & 1,1,2-triphenylethane & & \\
\hline$\underset{\text { (min) }}{T_{R}}$ & PVC-78 & $\underset{\text { (min) }}{T_{R}}$ & PVC-104 \\
\hline 3.6 & phenylacetaldehyde & 3.6 & phenylacetaldehyde \\
\hline 3.9 & ethyltoluene & 3.9 & ethyltoluene \\
\hline 4.6 & propenylbenzene & 4.6 & propenylbenzene \\
\hline 5.1 & 1-phenyl-1-nitroethane & 5.1 & 1-phenyl-1-nilroethane \\
\hline $\mathbf{5 . 4}$ & m- and p-ethylstyrene & 5.4 & m- and p-ethylstyrene \\
\hline 6.1 & 1-methylindane & 6.1 & methylallylbenzene \\
\hline 6.5 & methyl-1-indene & 6.3 & 1-methylindane \\
\hline 6.9 & naphthalene & 6.5 & methyl-1-indene \\
\hline \multirow[t]{5}{*}{8.2} & benzoic acid & 6.8 & naphthalene \\
\hline & & 8.5 & methylnaphthalene \\
\hline & & 10.6 & $\begin{array}{l}\text { 3-benzyl-6-bromo-3,4-dihydro- } \\
\text { 2-H-1,3-benzoin }\end{array}$ \\
\hline & & 11.1 & 4-methyl-2,6-di-tert-butylphenol \\
\hline & & 12.8 & 2,5-di-tert-amylquinone \\
\hline
\end{tabular}

¿ Retention times (inTables 8-14). 
Table 9. Pyrolysis products of PVC materials generated at high temperature, separated on the Carbowax-20M and SE-54 columns.

\begin{tabular}{|c|c|c|c|c|}
\hline Insulation & $\underset{(\min )}{T_{R}}$ & Carbowax-20M & $\begin{array}{c}T_{k} \\
(\min )\end{array}$ & SE-54 \\
\hline \multirow[t]{17}{*}{ Virgin PVC } & 3.7 & 1-methyl-2-ethylbenzene & 3.2 & 6,6-dimethylfulvene \\
\hline & 4.8 & m-methylstyrene & 3.7 & phenylacetaldehyde \\
\hline & 6.5 & styrene & 4.0 & methyltoluene \\
\hline & 7.4 & 3-methylindene & 4.5 & 2,2,4-trimethylheptane \\
\hline & 8.8 & naphthalene & 4.8 & o-methylstyrene \\
\hline & 10.0 & 1-methylnaphthalene & 5.4 & 2,5-dimethylheptane \\
\hline & 11.1 & biphenyl & 5.5 & 2-methylindane \\
\hline & 11.5 & 1,j-dimethylnaphthalene & 6.4 & methylallylbenzene \\
\hline & 11.9 & 2-ethylnaphthalene & 6.6 & 1,2-dihydronaphthalene \\
\hline & 14.0 & allylnaphthalene & 7.1 & azulene \\
\hline & 14.5 & fluorene & 8.2 & 3-methyl-1,2-dihydronaphthalene \\
\hline & 17.6 & phenanthrene & 8.6 & 2-methylnaphthalene \\
\hline & 19.1 & 4-methyl phenanthrene & 8.8 & 1-methylnaphthalene \\
\hline & 22.8 & 1,2,3,4-tetrahydrofluoranthene & 9.9 & acenaphthene \\
\hline & 24.1 & dioctylphthalate & 14.8 & phenanthrene \\
\hline & 24.7 & fluoranthene & 16.2 & 2-methyl anthracene \\
\hline & 26.4 & 5,6-benzo-7-phenylbicyclo $(2,2,1)$ hept-2-ene & & \\
\hline \multirow[t]{13}{*}{ PVC-3 } & 3.6 & xylene & 4.1 & ethyltoluene \\
\hline & 4.4 & p-ethyltoluene & 4.9 & propenylbenzene \\
\hline & 5.1 & isopropyl benzyl heptane & 6.4 & allyltoluene \\
\hline & 9.6 & naphthalene & 7.1 & naphthalene \\
\hline & 16.8 & 1-methylnaphthalene & 8.9 & methylnaphthalene \\
\hline & $11.9 \because$ & 1-ethylnaphthalene & 9.6 & phthalic acid \\
\hline & 12.1 & phenol & 16.5 & bufyl phthalate \\
\hline & 12.2 & biphenyl & & \\
\hline & 15.3 & phthalic anhydride & & \\
\hline & 15.5 & 2-hydroxy-4-methoxy-6-methylbenzaldehyde & & \\
\hline & 15.9 & ethylene glycol dibenzoate & & \\
\hline & 18.7 & dibutyl phthalate & & \\
\hline & 20.4 & 4-methylphenanthrene & & \\
\hline \multirow[t]{6}{*}{ PVC-78 } & 7.9 & 1-phenyl-1,2-propandione & 4.5 & isooctyl alcohol \\
\hline & 8.8 & naphthalene & 7.1 & azulene \\
\hline & 10.4 & 1-methylnaphthalene & 8.7 & benzoic acid \\
\hline & 11.4 & biphenyl & 9.0 & 1-methylnaphthalene \\
\hline & 11.9 & 1,2-dimethylnaphthalene & 10.0 & phthalic anhydride \\
\hline & 14.4 & phthalic acid & 17.4 & di-(2-ethylhexyl) phthalate \\
\hline \multirow[t]{7}{*}{ PVC-104 } & 3.5 & o-xylene & 3.1 & 6,6-dimethyl fulvene \\
\hline & 3.9 & isopropylbenzene & 3.7 & phenylacetaldehyde \\
\hline & 4.1 & styrene & 3.9 & bẹzyl ester \\
\hline & 9.5 & naphthalene & 4.1 & isopropylbenzene \\
\hline & 10.9 & 1-methylnaphthalene & 4.9 & methylstyrene \\
\hline & 12.1 & phenol & 5.6 & o-allyltoluene \\
\hline & 18.6 & anthracene or phenanthrene & $\begin{array}{l}11.4 \\
16.7\end{array}$ & $\begin{array}{l}\text { 2,6-di-tert-butyl-4-methyl phenol } \\
\text { stearic acid }\end{array}$ \\
\hline
\end{tabular}


Table 10. Pyrolysis products of Neoprene generated at high temperature and separated on the Carbowax-20M and SE-S4 columns.

\begin{tabular}{|c|c|c|c|c|}
\hline Insulation & $\underset{\text { (min) }}{T_{R}}$ & Carbowax-20M & $\underset{\text { (min) }}{T_{R}}$ & SE-54 \\
\hline \multirow[t]{10}{*}{ Virgin Neoprene } & 3.6 & o-xylene & 3.1 & 6,6-dimethylfulvene \\
\hline & 3.7 & chlorobenzene & 3.9 & n-proplybenzene \\
\hline & 4.0 & 1-methyl-3-ethylbenzene & 4.6 & acetophenone \\
\hline & 4.9 & m-chlorotoluene & 4.9 & propenylbenzene \\
\hline & 5.6 & m-methylstyrene & 5.6 & x-chloro-0-xylene \\
\hline & 6.0 & o-chloroethylbenzene & 6.1 & 2-phenylpropanol \\
\hline & 6.6 & 4-chloro-m-xylene & 6.4 & 7-methylbenzo( $\beta$ )furan \\
\hline & 8.3 & 1-methy!-: H-indene & 7.9 & benzoyl chloride and others \\
\hline & 9.7 & raphthaiene & & \\
\hline & $=$ & 1-rne: hy naphthalene & & \\
\hline \multirow[t]{14}{*}{ Neoprene-007 } & 3.8 & o-xylene & 3.1 & n-butyl chloroacetate \\
\hline & 4.8 & methylbenzoate & 3.3 & 2-nonynic acid \\
\hline & 5.7 & m-chlorotol:ene & 3.7 & benzyl chloride \\
\hline & 6.4 & indane & 3.8 & n-propylbenzene \\
\hline & 6.8 & o-chloroethylbenzene & 4.0 & 2-(1-phenylethylthio) phenol \\
\hline & 8.0 & 4-methylindane & 4.4 & 3-methyl-1,4-heptadiene \\
\hline & 9.1 & 1-methyl-1-H-indene & 4.7 & indane \\
\hline & 9.9 & chloroprene dimer & 5.0 & o-chloroethylbenzene \\
\hline & 10.5 & naphthalene & 5.4 & m-and p-ethylstyrene \\
\hline & 12.1 & 2-methylnaphthalene & 6.3 & methylindane \\
\hline & 21.1 & phenyl B-naphthylamine & 8.7 & methylnaphthalene \\
\hline & & & 12.3 & allylnaphthalene \\
\hline & & & 128 & diphenylmethane \\
\hline & & & 15.2 & 8-hydroxymethylquinoline \\
\hline \multirow[t]{7}{*}{ Neoprene-84 } & 3.7 & x-xylene & 9.8 & 2,3-dimethyl-1,2,3,4-tetra- \\
\hline & 4.6 & 1-methyl-3-ethylbenzene & & hydronaphthalene \\
\hline & 12.5 & benzothiazole & 25 & di-(2-ethylhexyl) phthalate \\
\hline & 12.7 & phenol & & \\
\hline & 13.5 & $x$-cresol & & \\
\hline & 15.8 & phthalic anhydride & & \\
\hline & 29.8 & dioctylphthalate & & $\therefore$ \\
\hline \multirow[t]{13}{*}{ Neoprene-435 } & 3.9 & $x$-xylene & 3.1 & 6,6-dimethyl fulvene \\
\hline & 4.4 & 1-methyl-3-ethylbenzene & 3.8 & benzyl chloride \\
\hline & 5.3 & benzyl chloride & 3.9 & n-propyl benzene \\
\hline & 5.9 & B-methylstyrene & 4.1 & benzyl benzoate \\
\hline & 7.2 & methylphenylacetylene & 4.8 & indane \\
\hline & 7.6 & $x$-methylindane & 6.4 & 5-methylindane \\
\hline & 8.7 & methyl-1-indene & 7.1 & azulene \\
\hline & 9.5 & chloroprene dimer & 12.6 & allylnaphthalene \\
\hline & 10.1 & naphthalene & & \\
\hline & 11.4 & methylnaphthalene & & \\
\hline & 12.4 & ethylnaphthalene & & \\
\hline & 14.1 & acenaphthene & & \\
\hline & 15.4 & 1-allylnaphthalene & & \\
\hline
\end{tabular}


Table 11. Pyrolysis products of rubber generated at high temperature and separated on the Carbowax-20M and SE-54 columns.

\begin{tabular}{|c|c|c|c|c|}
\hline Insulation & $\underset{\text { (min) }}{T_{\mathrm{R}}}$ & Carbowax-20M & $\underset{\text { (min) }}{T_{R}}$ & SE-54 \\
\hline \multirow[t]{10}{*}{ Rubber-12 } & 4.3 & styrene & 7.1 & azulene \\
\hline & 5.2 & phenylacetylene & 18.0 & di-N-amylphthalate \\
\hline & 5.4 & o-methylstyrene & & \\
\hline & 6.7 & 1-chloroindane & & \\
\hline & 8.0 & methyl-1-indene & & \\
\hline & 9.6 & naphthalene & & \\
\hline & 11.2 & 2-methylnaphthalene & & \\
\hline & 12.2 & biphenyl & & \\
\hline & 12.5 & p-isopropenylacetophenone & & \\
\hline & 14.1 & biphenylene & & \\
\hline
\end{tabular}

Rubber-134

Rubber-138

Rubber-1132

$\begin{aligned} 3.3 & \text { ethylbenzene } \\ 4.3 & \text { styrene } \\ 8.2 & \text { methyl-1-indene } \\ 8.6 & \text { isobutylphenone } \\ 9.6 & \text { napthalene } \\ 10.9 & \text { 1-methylnaphthalene } \\ 12.0 & \text { phenol } \\ 12.2 & \text { biphenyl } \\ 15.9 & \text { benzoic acid }\end{aligned}$

\section{1,2-dimethylbenzene}

benzocyclobutane

phenylcyclopropane

benzaldehyde

1-methyl-1H-indene

acetophenone

azulene

naphthalene

$\beta$-phenylethyl acetate

methylnaphthalene

benzothaozole

phenol

biphenyl

$\beta$-phenylethylformate

biphenylene

1,3-diphenylpropane

1,2-benzoloxybutane

palmitic acid

\section{styrene}

naphthalene

methylnaphthalene

phenol

Phthalic anhydride

benzoic acid

butyl phthalate allylbenzene-1-phenyl-1-nitroethane

1-phenyl-1,2-propandione

3-cyclopentyl-2',4'-di-methylphenone

methyl-3-(2,5-dimethybenzoyl) butanoate 1,2-dimethyl-3-ethylbenzene 1-phenyl-1-nitroethane 1-chloroheptadecane phthalic anhydride butylmethyl phthalate cyclotetracene

isopropylbenzene

phenylacetaldehyde

1-methyl-2-ethylbenzene

isopropylbenzene

methylstyrene

propenylbenzene

chlorindene

1,7-ethene-spiro- $(2,6)$ mono-

4,8-diene-2,8-lactone

naphthalene

$\beta$-phenylethyl acetate

acenaphthene

1,3-diphenylpropane

dioctylphthalate

di-(-2-ethylhexyl)phthalate

6,6-dimethylfulvene

ethyltoluene

allylbenzene

azulene

phthalic anhydride

d-n-amyl phthalate

amyl phthalate

isobutyl-o-phthalate

isopropyl phthalate 
Table 11. (Continued)

\begin{tabular}{|c|c|c|c|c|}
\hline Insulation & $\underset{(\mathrm{min})}{T_{k}}$ & Carbowax-20M & $\underset{\text { (min) }}{T_{R}}$ & SE-54 \\
\hline \multirow[t]{11}{*}{ Rubber-1138 } & 3.4 & xylene & 3.2 & styrene \\
\hline & 3.7 & 1,2,3,4-tetramethylbenzene & 3.4 & isopropylbenzene \\
\hline & 4.3 & styrene & 3.8 & phenylacetaldehyde \\
\hline & 6.0 & cyclopropylbenzene & 4.2 & alpha-methylstyrene \\
\hline & 7.1 & benzaldehyde & 4.8 & allylbenzene \\
\hline & 8.6 & methylphenylheptane & 5.2 & n-butylbenzene \\
\hline & 9.6 & naphthalene & 6.6 & n-phenylbenzene \\
\hline & 11.2 & methylnaphthalene & 13.2 & 1,3-diphenylpropane \\
\hline & 12.0 & phenol & 18.5 & n-butyl-o-phthalate \\
\hline & 12.3 & biphenyl & & \\
\hline & 14.9 & 1,3-diphenylpropane & & \\
\hline
\end{tabular}

propyne. Liquid pyrolyzates generated at high temperature consist mainly of aromatic compounds and high-molecular-weight aliphatic hydrocarbons (Table 12).

\section{Polyurethane}

High-temperature pyrolysis did not produce any detectable effect on the generation of $\mathrm{C}_{1}-\mathrm{C}_{4}$ hydrocarbons (Table 13). The mixture consisted of various aromatic compounds. The main difference between medium-temperature and hightemperature pyrolysis is that the pyrolyzate generated at high temperature consists of a wider variety of products. Some of these products are halogenated, which are probably degradation products of a flame retardant used in this formulation.

\section{Nylon}

Both the medium- and high-temperature pyrolysis of nylon rendered the following hydrocarbons: methane, ethylene, acetylene, ethane, propane, propylene, propyne, isobutane, n-butane, 1-butene, isobutylene, cis-2-butene, trans-2-butene, ethylacetylene, 1,3-butadiene, and pentane. High-temperature pyrolysis affects the production of the minor constituents of the liquid pyrolyzate rather than changes the general mechanism of degradation. High temperature generated larger amounts of n-butane, 1-butene, and isobutylene than medium temperature. The liquid pyrolyzate generated at high temperature, as opposed to that from medium temperature, again consisted primarily of caprolactam and low amounts of minor constituents comprised of creosol, 2,5-dimethylbenzene, 2,-5-dimethylbenzoate, methyl-3-butanoate and tetrahydro-quinoline.

\section{Mylar}

Table 14 compares high-temperature pyrolysis of polyethylene terephthalate with Mylar. Similar amounts of $C_{1}-C_{3}$ products are produced at both medium and high temperatures, however, polyethylene terephthalate forms large amounts of $\mathrm{C}_{4}$-hydrocarbons at both medium and high temperatures, such as n-butane, 1-butene, isobutylene, cis-2-butene, and trans-2-butene.

\section{Conclusions}

High-temperature pyrolysis leads to formation of large amounts of light hydrocarbons as well as to production of substantial amounts of aromatic species. Our results from FY 83 confirmed earlier findings in that all the insulations we investigated form detectable amounts of light hydrocarbons upon smoldering or flaming combustion. These are detected in the very early degradation stages of the samples pvrolyzed either under controlled laboratory conditions or ignited in the large-scale test cell. Such information is useful for selecting or designing appropriate early warning alarm systems for buildings housing costly equipment. Also, the extensive GC/MS analysis of the liquid pyrolyzates confirmed that this information can aid in isolating insulations which incorporate flammable plasticizers. 
Table 12. Pyrolysis products of polyethylene generated at high temperature and separated on the Carbowax-20M column.

\begin{tabular}{|c|c|c|}
\hline Insulation & $\underset{(\min )}{T_{n}}$ & Carbowax-20M \\
\hline \multirow[t]{13}{*}{ Virgin polyettiylene } & 5.3 & 1,3-dimethyl-4-cyclopentane \\
\hline & 7.2 & 1-hexadecene \\
\hline & $?$ & naphthalene \\
\hline & $?$ & 1-methyl-2-cyclohexylcyclohexane \\
\hline & 10.4 & x-methylnaphthalene \\
\hline & 10.6 & o-nenthane \\
\hline & 11.4 & phenylbenzene \\
\hline & 11.6 & methyldicyclohexylmethane \\
\hline & 12.4 & acenaphthene \\
\hline & 13.2 & biphenylene \\
\hline & 13.6 & 1,1-dicyclohexylpentane \\
\hline & 22.9 & dihexyldiacetylene \\
\hline & 25.0 & dioctylphthalate \\
\hline \multirow[t]{5}{*}{ Polyethylene-77 } & 3.7 & styrene \\
\hline & 6.1 & 1-methylphenylacetylene \\
\hline & 8.9 & naphthalene \\
\hline & 10.2 & liexahydrofarneool and methylnaphthalene \\
\hline & 10.5 & 3-methylpentine \\
\hline \multirow[t]{6}{*}{ Polyethylene-95 } & 3.1 & undecanol-1 \\
\hline & 4.1 & oct-1-ene \\
\hline & 5.3 & acetic acid \\
\hline & 6.4 & 4,6,8-trimethylnonene-1 \\
\hline & 7.7 & 2,2-dimethyl-1-acetylcyclopentane \\
\hline & 7.8 & 1-hexadecene \\
\hline
\end{tabular}

Table 13. Degradation products from pyrolysis of Polyurethane-89 separated on the Carbowax20M and SE-54 columns.

\begin{tabular}{|c|c|c|c|}
\hline $\begin{array}{c}T_{R} \\
(\mathrm{~min})\end{array}$ & Carbowax-20M & $\underset{(\mathrm{min})}{\mathrm{T}_{\mathrm{R}}}$ & SE-54 \\
\hline 3.1 & o-xylene & 3.0 & phenylacetylene \\
\hline 3.3 & chlorobenzene & 3.2 & 1,2-dimethyl-3-ethylbenzene \\
\hline 3.6 & styrene & 3.5 & bicyclo (5-10) oct-3-ene \\
\hline 4.4 & 1,4-dichlorobutane & 3.9 & benzotriazole \\
\hline 4.6 & phenylacetylene & 4.3 & benzamide \\
\hline 5.6 & di-(4-chlorobutyl) ether & 4.7 & 4-methylstyrene \\
\hline 5.9 & indene & 4.9 & methylphenylace tylene \\
\hline 8.5 & 1,2,3,4-tetrachlorocyclopenta-1,3-diene & 5.2 & 4-methyl-1-aziridinecarboxanilide \\
\hline 8.9 & naphthalene & 6.8 & naphthalene \\
\hline 9.3 & 4-heptanol & 8.6 & methylnaphthalene \\
\hline 10.1 & 2-methylnaphthalene & 9.8 & di-(4-chlorobutyl) ether \\
\hline 11.0 & bis (4-chlorobutyl) ether & 10.5 & biphenyl \\
\hline 12.4 & benzyl bromide & 14.3 & phenanthrene \\
\hline 13.3 & biphenyl & & \\
\hline 13.5 & methyl quindine & & \\
\hline 16.7 & n-butyl-N-phenylcarbonate & & \\
\hline 17.7 & phenanthrene & & \\
\hline 23.4 & pyrene & & \\
\hline 25.3 & fluoranthene & & \\
\hline 26.5 & azidobiphenyl & & \\
\hline
\end{tabular}


Table 14. Pyrolysis products of mylar and polyester generated at high temperature and separated on the Carbowax-20M and SE-S4 columns.

\begin{tabular}{|c|c|c|c|c|}
\hline Insulation & $\frac{T_{R}}{(m i n)}$ & Carbowax-20M & $\begin{array}{c}\mathrm{T}_{n} \\
(\mathrm{~min})\end{array}$ & SE-54 \\
\hline \multirow[t]{7}{*}{ Mylar-139 } & 3.3 & octadecanol-1 & 3.2 & 2-tert-butyl-4-methylfuran \\
\hline & 8.7 & naphthalene & 3.6 & 4-methyl-2-heptanone \\
\hline & 24.7 & dioctylphthalate & 3.9 & 1,2,4-trimethylbenzene \\
\hline & & & 4.2 & 6-methyl-1-heptanol \\
\hline & & & 4.8 & 1-methylphenylacetylene \\
\hline & & & 6.7 & azulene \\
\hline & & & 23.3 & dioctylphthalate \\
\hline \multicolumn{5}{|l|}{ Polyethylene } \\
\hline \multirow[t]{10}{*}{ terephthalate } & 3.6 & styrene & 3.2 & cyclooctatetraene \\
\hline & 5.1 & methylstyrene & 3.9 & benzaldehyde \\
\hline & 5.3 & acetic acid & 4.2 & methylstyrene \\
\hline & 6.3 & benzaldehyde & 6.2 & methyl benzoate \\
\hline & 7.0 & m-divinylbenzene & 10.1 & benzoic acid \\
\hline & 7.5 & methyl benzoate & 10.5 & p-methyl benzoic acid \\
\hline & 7.9 & ethyl-2-keto-2-phenylethanoate & 11.5 & ethylbenzoic acid \\
\hline & 8.1 & ethyl benzoate & 13.4 & methyl terephthalate \\
\hline & 10.2 & methyl-3-(2,5-dimethyl benzoyl) butanoate & 18.1 & phenyl benzoate \\
\hline & 11.5 & biphenyl & & \\
\hline
\end{tabular}

\section{Reliability Study on the LLNL Water-Supply System}

With this section, the reliability analysis of fire-sprinkler systems, a major portion of our firerisk analysis which began in FY 80, is completed. This reliability study illustrates the application of a powerful analytical tool called digraph-fault-tree methodology. ${ }^{11}$ Although it is specifically applied to the LLNL water-supply system, this methodology is ideal for complex systems analyses of large facilities or technologies such as special nuclear materials' safeguards, nuclear-powerplant cooling systems, large-research-facility control systems, large-experiment designs, fireprotection systems, etc. Dunglinson et al. not only describes the technique in detail but also presents examples of actual studies in the chemical process industry. ${ }^{12}$

There are a number of disadvantages and deficiencies in traditional fault-tree analysis that digraph alleviates. Since a detailed report will be published in the near future, we will present a summary of the digraph-fault-tree study. We analyzed the reliability of the Mocho water-supply system, LLNL's primary water supply, to establish whether adequate water would be available in the event of a major fire. The digraph procedure generated a fault tree of the water-supply system.
The initiating-enabling-event-interval reliability approach is used to perform a probablistic evaluation of the fault tree and to compute various system reliability characteristics, such as the unavailability of the water-supply system in the event of a major fire. ${ }^{12}$

\section{Mocho Water Supply and LLNL Monitoring System}

Figure 14 shows the water-supply system to LLNL. The main source of water to LLNL is the Hetch Hetchy Aqueduct, located $800 \mathrm{ft}$ below ground level at the Mocho Pumping station, which is located $8 \mathrm{mi}$ south of LLNL (Site A). The water is first pumped to the surface and into the standpipes (Site B). The purpose of the standpipes is to prevent water hammer at pump discharge. These two standpipes have a capacity of 20,996 gallons each. The water flows by gravity from the standpipes to three main storage tanks (Site C) located $1 / 2$ mi south of LLNL on the hill above Sandia National Laboratories (SNL). Three storage tanks have a total capacity of $1,238,800$ gallons (Site $\mathrm{C}$ ). The storage tanks provide the head 


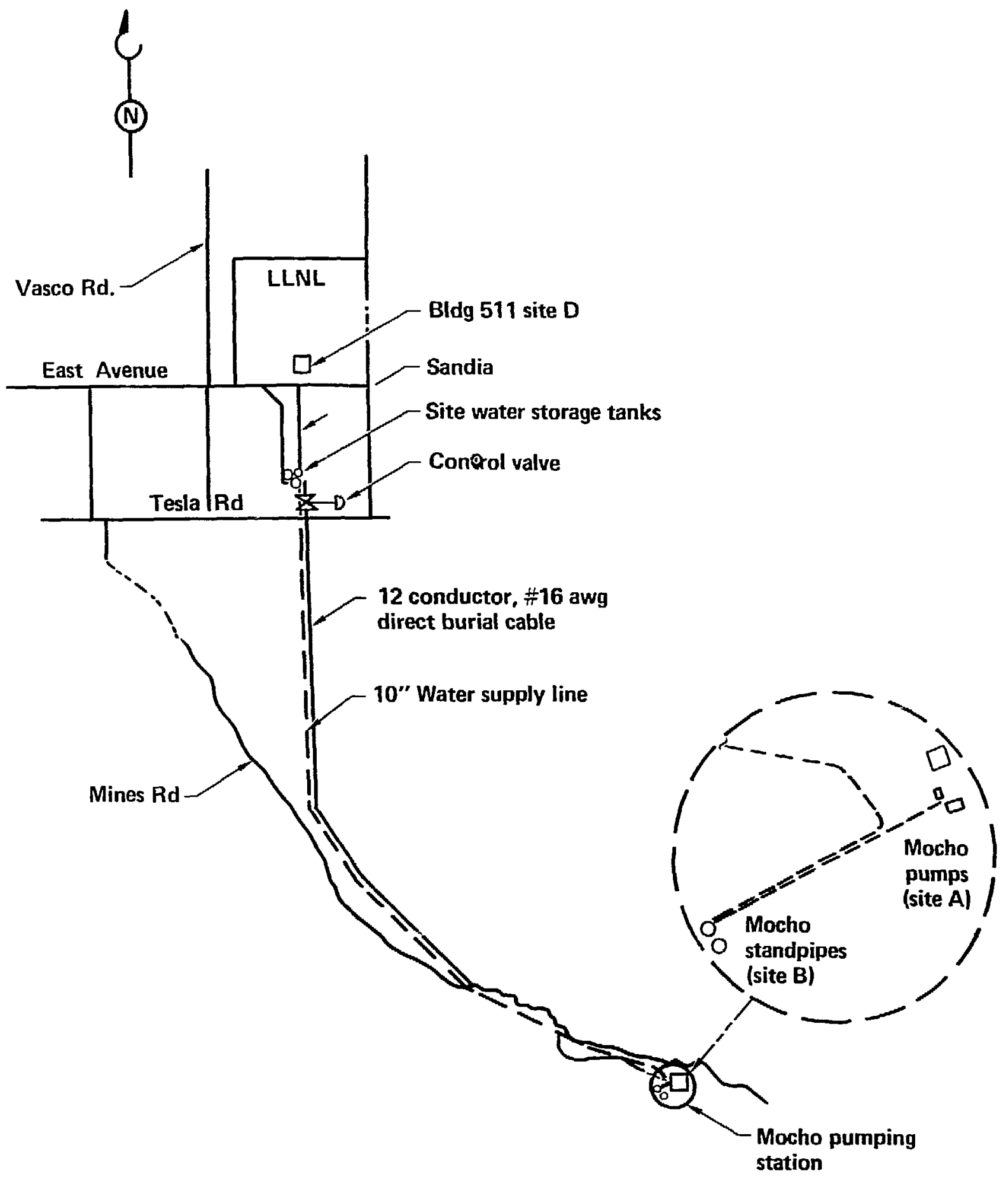

Figure 14. Site plan of existing system. 
pressure necessary to supply LLNL. The tanks and standpipes are all at atmospheric pressure. The Central Control Room for the system is located on-site in Bldg. 511 (Site D).

As an alternate or standby water supply, LLNL has water available from the Zone 7 water district. This water supply is used only during times when Hetch Hetchy water is unavailable due to tunnel maintenance, pump failure at the Mocho Pumping Station, or line failure between the Mocho standpipes and the storage tanks. Personnel on-site must activate the Zone 7 water supply manually.

Figure 15 is a simplified schematic of the LLNL water-control system. The system consists basically of two feedback subsystems: (1) the water-level control for the Mocho standpipes and (2) the water-level control for the storage tanks. Any two of the three pumps at Site A controls the water level in the standpipes. Water level in the storage tanks is controlled by opening a valve that causes the Mocho standpipes to drain (Site B). Gravity feeds water as needed to LLNL from the storage tanks. Alarms, status indicators, and control sigrals are transmitted via frequency division multiplexed frequency shift tone equipment. Selector switches, relays, water-level meters, and pilot lights display the data being transmitted and received on a control console in Bldg. 511 (Site D). Manual commands from the control console can open or close valves at the water-storage tanks, and start and stop pumps at the Mocho pumping station. The water level in the standpipes and storage tanks is continuously monitored in Bldg. 511. Any abnormal condition, such as a high- or low-water level in the storage tanks or in the standpipes, or any pump failure, initiates an au lible and visual alarm on the control console.

\section{Analysis of the Mocho System}

We first had to understand and model the components of the water-supply-control system. Digraph-fault-tree analysis uses steps common to traditional fault-tree analysis. In assessing the Mocho water-supply system in the event of a major fire, we found that 16 single events would cause the control loop that monitors storage tank level to fail. These failures would go undetected in Bldg. 511 because the feedback loop performs both control and detection functions. Based on this, we recommend that each tank have its own independent water-level sensor. If this is done, then we estimate that system availability would increase by a factor of 50 . Restoring this independent measurement would result in no single event minimal cut sets in the system in which failures would go undetected.

We will briefly describe the digraph-faulttree methodology used to arrive at our recommendations.

\section{Defining the Top Event}

The Top Event in this analysis is "Insufficient Supply of Water in Storage Tanks and No Detection of Same in Bldg. 511." Note that we did not consider earthquake effects on the Mocho system.

Based on firefighting experience in the chemical industry, LLNL's Fire Safety Division defined the amount of water necessary to extinquish a major fire on-site: a continuous flowrate of 3500 gallons per minute (gpm) for 4 hours, for a total of 840,000 gallons. Besides, the 1,283,800-gallon capacity of the three storage tarks, standpipes $A$ and B contain 41,992 total gallons, and 180,180 gallons also sit in the line from the standpipes.

In addition, we must include the makeup capacity of the two Mocho pumps (1 lead and $1 \mathrm{lag}$ ) during this 4-hour period. The lead pump, No. 3 , has a capacity of $1100 \mathrm{gpm}$; each of the lag pumps, No. 1 or 2, has a 500 -gpm capacity. In 4 hours, there is a total capacity of $1600 \mathrm{gpm}$, or 384,000 gallons. Therefore, the total capacity of the whole system plus makeup is $1,889,972$ galions.

During 1981, the maximum daily wetnr consumption was 950,000 gallons. Subtracting this amount from the Mocho system capacity leaves 939,972 gallons to fight a major fire, which exceeds the recommended 840,000 gallons. If the system is working, then an adequate supply of water will be available for the postulated fire.

In the 15 years the Mocho system has been operating, the storage tanks have drained dry twice due to human error. Such errors will lead to an inadequate supply of water in the storage tanks, and no one will detect it in Bldg. 511. Since the total of the pump makeup plus the standpipes and the line from the standpipes is only 606,000 gallons, at least an additional 234,000 gallons must be in the storage tanks to meet the 840,000 -gallon requirement $(840,000-606,000=234,000)$. Therefore, if the level in the storage tanks drops below 234,000 gallons, there will not be enough water to extinquish the fire.

A low-level condition in the tanks generates an alarm in Bldg. 511. Depending on the event(s) that caused the low level, LLNL personnel will take the appropriate measure, such as activating Zone 7 supplies. 


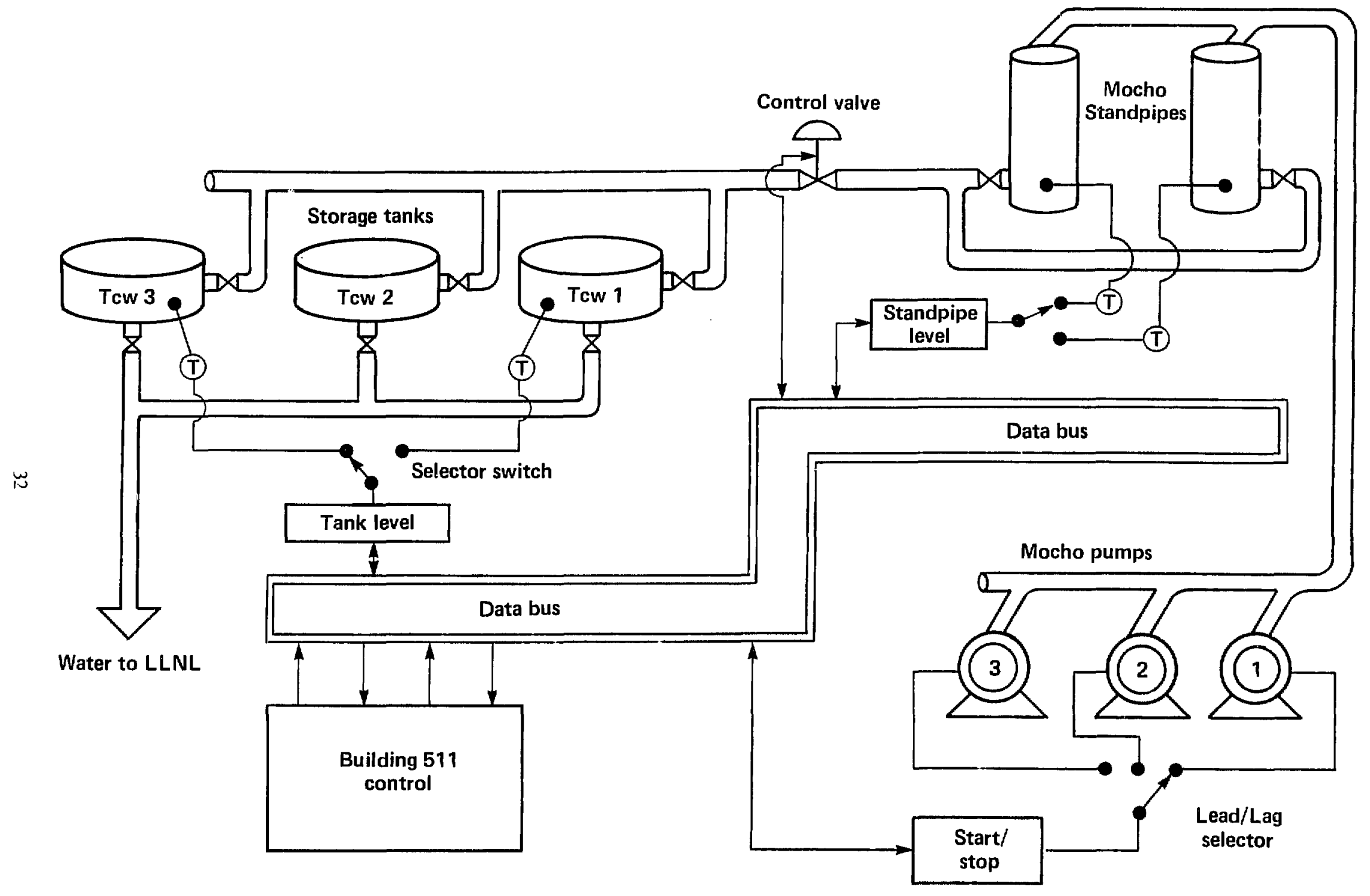

Figure 15. Mocho-water control system. 


\section{Understanding the Water-Supply System}

By taking tours of the entire water-supply system and interviewing LLNL personnel familiar with the system, we :dentified the following information, germane to digraph-fault-tree analysis.

The independent measurement of water level in the storage tanks was removed which left only one sensor for three tanks. Pump No. 3, an 1100gpm pump, is the lead pump; a 500-gpm pump is the lag pump. In a No. 3-failure, either No. 1 or No. 2 becomes the lead pump. A visit to the Site $A$ pumps is required in the event of a No. 3-failure. With No. 3 out of service, the water makeup to the standpipes takes longer but the system can be successfully operated in this mode. The main water valve will not open if the standpipe is in a lowwater alarm condition or if the water tanks are in a high-water alarm condition. A spurious signal for either of the above ronditions will cause the main water valve to close, and this results in the storage tanks standing at low level. In the event of a complete failure of the Mocho system, it takes approximately $15 \mathrm{~min}$ to cut in the Zone 7 water supply. The existing controls for the Mocho system include over 100 mechanical relays for logic and timing. Understanding the operational sequence of the control system was important to analyzing its reliability in any detail.

\section{Event Sequence for Storage-Level Control}

Water usage by SNL or LLNL will cause the water level in the storage tanks to drop. When the water level drops to $12 \mathrm{ft}-6$ in., a water-pressure transducer causes the automatic water valve to open. When the valie opens, water begins to flow from the Mocho standpipes. This water flows into the top of the No. 2 storage tank that is connected to No. 1 and No. 3 through service valves located at the bottom of the tanks. Water continues to flow through the automatic valve arid fill the three tanks until a level of about $14 \mathrm{ft}$ is reached, at which time the automatic valve closes and no water flows.

\section{Event Sequence for Standpipe-Level Control}

As the automatic water valve at the storage tanks opens and water begins to flow from the Mocho standpipes, the water level in the standpipes drop. When this level drops to $12 \mathrm{ft}-6$ in., the No. 3 lead pump starts pumping into the top of No. 1 standpipe, connected by bottom piping to No. 2 standpipe, from which wis.r flows to the storage tanks. However, water flows through the automatic water valve faster than No. 3 can pump, so the water level continues to drop. When the standpipe water level reaches $8 \mathrm{ft}-8$ in., the lag pump starts pumping. The combined output of both lead and lag pump is greater than the amount of water flow through the automatic valve, so the water level will now rise in the standpipe. When the water level reaches $12 \mathrm{ft}$ 10 in., the lag pump drops out. It will, however, continue to cycle on when the standpipe level drops to $8 \mathrm{ft}-8$ in. and cycle oft as the level rises to $12 \mathrm{ft}-10$ in. When the automatic water valve at the storage tanks closes, the level in the standpipe rises until it reaches $13 \mathrm{ft}-5$ in., at which point the lead pump cuts off and everything comes to a rest.

\section{Failure Modes and Effects Analysis}

We performed a detailed Failure Modes and Effects Analysis (FMEA) on the Mocho system. LLNL personnel provided input for the FMEA. The results from this study provided much of the information to construct the digraph and fault tree and the probabilistic evaluation of the fault tree. The advantage of a FMEA is that LLNL personnel can provide information for the analysis without a knowledge of the digraph-fault tree procedure.

\section{System Digraph}

A digraph is a multivalued logic model useful in constructing fault trees of control systems. The digraph consists of nodes and edges (or arrows) that connect the nodes. A node represents a process variable and the edge represents the gain, or the relationship between the nodes. A top event is defined as a deviation, i.e., a disturbance and is the starting variable in the digraph. The digraph is constructed deductively, similar to constructing a fault tree. The limit of resolution in the digraph is equipment failure, human error, or environmental conditions.

The next step in the digraph precedure is to find the control loops in the digraph. A synthesis algorithm is devised to construct the digraph from the fault tree. Basically, the synthesis algorithm delineates how a control loop can cause or pass a disturbance resulting in the occurrence of the Top Event.

The advantages of constructing a digraph is that the topology of the system variables is displayed and that the digraph resembles the system schematic. In addition, the digraph can consider multivalued logic and timing. By contrast, a fault 
tree bears no relationship to the schematic, and it is difficult to consider multivalued logic and timing in fault-tree analysis.

\section{Digraph Construction}

The system digraph constructed for our study is similar in scope to the system digraph made for the LLNL Material Control St:idy. ${ }^{13}$ The purpose of a material-control system is the prevention of theft of Special Nuclear Materials (SNM), like plutonium, from nuclear facilities. The materialcontrol system consists of procedures, monitors, computers, and a security force designed to stop theft, both covert and overt.

The LLNL study focused on covert threat via an insider problem, and a prototype facility, called the Test Bed, was designed. ${ }^{13}$ The assessment of the Test Bed facility generated a system digraph with a Top Event Node, "Successful Theft of SNM from the Test Bed." Plutonium nitrate is stored in tanks that contained bubblers which measured static pressure or level. As the adversary attempts to steal SNM, the tank level should decrease and generate an alarm. As the adversary commits acts necessary to steal the SNM, a series of negative feedforward loops are activated, called cancellation loops. These loops generate a safeguards response in preventing the adversary from stealing SNM.

For the adversary to be successful, all these loops must fail. Failure can occur because of random monitor failure, inadequate monitormeasurement sensitivity, and adversary activity, including equipment tampering and collusion. The synthesis algorithm creates an AND gate in the fault tree each time a cancellation loop fails.

In the Mocho study, we are concerned with human error and/or equipment failure that causes a low water level in the storage tanks. Also, we are concerned with failure of LLNL personnel to take action when a low water level occurs. Hence, we see that the methodology used in generating the material-control digraph is applicable directly to our analysis of the Mocho system.

\section{The Preliminary System Digraph}

The preliminary system digraph shows the structure of the detailed system digraph (Fig. 16). The top event variable in the digraph is "Flowrate to LLNL." The cycles in the digraph show the two basic feedback loops- (1) the storage-tank-levelcontrol feedback loop and (2) the standpipe-levelcontrol feedback loop.

The sensed variable in both cases is static pressure and the manipulated variable is flowrate through the main control valve (for the storage tanks) or through the Mocho pumps (for the standpipes). An arrow from one variable (the independent variable) to the other variable (thie dependent variable) indicates that a change or deviation in the independent variable causes a change in the dependent variable.

\section{The Detailed Digraph}

The detailed system digraph is segmented according to sites: Site A, the Mocho pumps; Site B, the Mocho standpipes; Site $C$, the storage tanks, and Site D, Bldg. 511. Each digraph was made using the control system schematic. Because of the magnitude of the detailed system digraphs, only Site B (the Mocho standpipes) is included as an example in Appendix B.

\section{Fault-Tree Construction}

Appendix $C$ displays the fault tree. The causes are displayed for the Top Event:

- One or more storage tank drain valves closed and no detection of low storage tank level.

- Insufficient flow through control valve and no detection in Bldg. 5 ?

Once, during the hisis: of the system, a drain valve to a storage tank had been closed and the selector switch had not been changed to measure the water level in tank No. 1. This event caused the system to drain and simultaneously inactivated the control loop that operates the valve since a full tank was being monitored. Hence, the remaining two tanks drained with no detection in Bldg. 511. The event, excessive system demand, has been included in the fault tree for completeness. However, as described earlier, this event is no longer a possibility and so will be excluded from further consideration.

It is important to note that if the storage tank level feedback loop is inactive or out of tolerance, then low level will occur without detection level in Bldg. 511. This is because the feedback loop is used simultaneously to (1) control level in the storage tanks, and (2) to send a signal to Bldg. 511 in the event of low level. Hence, failure of the control elements on the feedback loop directly causes the top event to occur. If the control valve is open, and the loop fails out of tolerance, then the control loop will command the valve to close for a longer period of time than desired, resulting in low level in the storage tank. If the loop is inactive, then the control valve will fail to open when it should, again resulting in low storage tank level. 

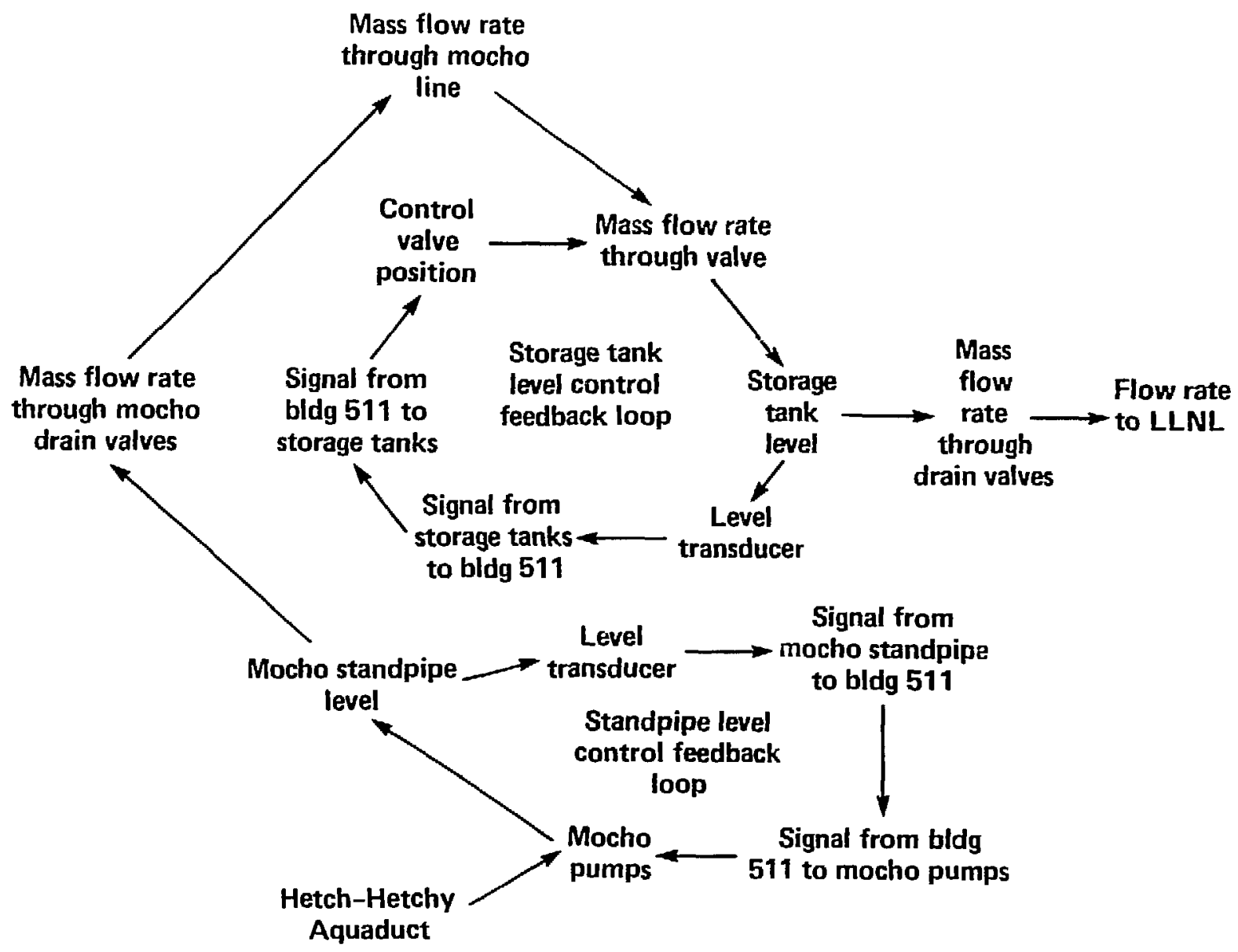

Figure 16. Preliminary system digraph.

A close-all-valve signal can result in the valve being closed too long. Two things can cause this:

- A spurious high storage tank level signal.

- A low standpipe level signal (generated either spuriously or due to actual failures that can cause low standpipe level).

The cause of low standpipe level can be due to the feedback loop being out of tolerance or inactive. Another cause of low tank level is an insufficient supply from the Mocho pumps. Note that we do not consider the case of drained Mocho standpipes. This is because a low standpipe level will cause the control valve to close and result in a low level in the stcrage tanks, which means that the fault tree logic for draining the standpipes will generate nonminimal cut sets since additional features must occur to drain the standpipes. However, we do consider draining the pipelines from the standpipes. This can occur by simply closing the drain valve in standpipe No. 2. Since the standpipe level is constant in this case, the valve will continue to remain open until the pipe from the standpipe is drained. Note that throughout the fault tree, that when a detection loop fails, an AND gate is generated. This is a result of the feedforward operator described in Lambert. ${ }^{11}$

\section{Qualitative Fault-Tree Evaluation}

The fault tree contains 98 basic events. In addition, there are a total of 640 minimum-cut (mincut) sets. Min-cut sets are combinations of basic events that cause the Top Event to occur. Min-cut sets also are known as the system failure modes. The number of min-cut sets according to order is given below (order refers to the number of basic events in a min-cut set):

$\begin{array}{lccccccc}\begin{array}{l}\text { Order } \\ \text { Min-Cut }\end{array} & 1 & 2 & 3 & 4 & 5 & 6 & 7 \\ \text { Sets } & 16 & 19 & 134 & 244 & 163 & 56 & 8\end{array}$


The 16 singie-event min-cut sets are single failures of control devices on the storage tank level reedhack loop as described earlier. Of the 98 basic events, 72 are initiating ev nts a. 2 d 26 are enabling events. As described in Dunglinson et al., enabling events inactivate system mitigative or protective features but do not cause the Top Event to occur. ${ }^{12}$ for example, an inactive alarm or burned-out light does not cause low level but does fail the operator in the event of an alarm condition. For initiating events we must compute their frequency of occurrence, for enabling events, their demand unavailability when the initiating event occurs. Reliability data for the 98 basic events were obtained from actual system experience during the last 15 years.

For initiating events, wc assume a fault duration time of $1 \mathrm{~h}$. This includes the amount of time required for Bldg. 511 personnel to diagnose the cause of failure and take sction after a failure of the Mocho system has occurred.

For the Top Event to occur, we assume no detection in Bldg. 511. However, low water pressure will be detected on-site. The 1-h fault duration time corresponds to the time after detection has occurred on-site. The fault duration time for enabling events, 0.13 years, corresponds to the average time a failure can exist with an inspection interval of three months.

\section{Probabilistic Evaluation of the Fault Tree}

We used the computer code, IMPORTANCE, to evaluate probabilistically the Mocho system fault tree. ${ }^{14}$ The following probabilistic measures were computed for the Mocho system: events,

- Frequency of occurrence of initiating

- Frequency of occurrence and mean occurrence time when an insufficient supply of water exists in the system,

- Unavailability of the Mocho system when a major fire occurs, and

- Ranking of initiating events, enabling events and min-cut sets according to their probabilistic importance.

Probabilistic importance assesses the quantitative contribution of enabling events, initiating events, and min-cut sets to the occirrence frequency of the Top Event. A probabilistic ranking according to importance is necessary in identifying important contributors because it is virtually impossible for an analyst to visually inspect all the min-cut sets and to assess the relative contribution of a component to system failure. This is particularly true for the Mocho system whose fault tree contains 98 basic events and 640 min-cut r.t.

\section{Initiating-Event Fault Tree}

One fault tree was generated by simply taking the Boolean union of all initiating events. Hence, th:- idult tree generated 72 single-event min-cul sets, since there were 72 initiating events. Tajle 15 displays the results of this fault tree. The Top-Event frequency of occurrence is $\mathbf{2 0 . 4}$ per year. We can think of this number as the number of challenges to the system yearly: This number is consistent with actual historical data. Table 15 also lists the ranking of initiating events through rank 9. We see that the following events are important:

- PG\&E power failure.

- Oiler relay failure (at Mocho pumps).

- Noise on transmission line.

We assume that the dominant failure cause of the close-all-valves tran.mitter is noise on the line.

\section{Mocho System Fault Tree}

Table 16 lists the system-reliability characteristics of the Mocho system fault tree. We predict that, on the average of 3.1 times per year, the Mocho system will have an inadequate supply of water to extinguish a major fire at LLNL. It must be pointed out that this number corresponds to a low level in the storage and not necessarily to a totally dry condition. Another measure of system adequacy is the demand unavailability of the system given a major fire. The demand unavailability is calculated to be $3.6 \times 10^{-4}$. We compare this number to the actual historical data. During the 15-year life of the system, it has been dry twice. If we assume that the system was unavailable for 4 hours each time, this results in a system unavailability of ( 8 hours $\times 1$ year $/ 8760$ hours) (system lifetime $/ 15$ years) $=6.1 \times 10^{-5}$.

Since this number does not include other times in which the storage tanks might have been low rather than dry, we see that the calculated unavailability, $3.6 \times 10^{4}$, ag ees reasonably well with the historical data, $6.1 \times 10^{5}$. Table 16 also ranks the initiating events through rank 9 . We see that the basic events which are single-event mincut sets rank the highest. The one exception is the PG\&E power failure that requires failure of the backup-power slipply system. These singles are 
Table 15. Results from the initiating-event fault tree. The mission time is $1=y r s$.

\begin{tabular}{|c|c|c|c|c|}
\hline Rank & Basic event description & Importance & $\begin{array}{l}\text { Failure sate } \\
\text { per year }\end{array}$ & $\begin{array}{c}\text { Mean fault duration } \\
\text { (hr) }\end{array}$ \\
\hline 1 & I-V-CI PG\&E power failure & 0.232 & 5.00 & 1.00 \\
\hline 2 & 1-P-A2 Oiler failure relay I'CW \#1 & 0.155 & 3.33 & .00 \\
\hline 2 & 1-P-A1 Oiler failure PCW \#3 & 0.155 & 3.33 & 1.00 \\
\hline 3 & I-V-D1 Close all valve transmitter failure on & 0.464 E-01 & 1.00 & 1.09 \\
\hline 3 & I-V-D2 Noise on line to control valve transmitter & $0.46+\mathrm{E}-01$ & 1.00 & 1.00 \\
\hline 3 & I-P-D1 Noise on line from standpipe to BIdg. 511 & $0.4 G 4 E-01$ & 1.00 & 1.00 \\
\hline 4 & 1-P-A2 Control power contacts R3-1 transfer open & $0.218 \mathrm{E}-01$ & 0.47 & 1.00 \\
\hline 4 & 1-P-A1 Control power contacts R9-1 transfer open & $0.218 \mathrm{E}-91$ & 0.47 & $\mathbf{i . 0 0}$ \\
\hline 5 & I-V-C1 High resistance WLT \#1 transducer & 0.186 E-01 & 0.40 & 1.00 \\
\hline 5 & 1-P-B1 High resistance standpipe pressure transducer & $0.186 \mathrm{E}-01$ & 0.40 & 1.00 \\
\hline 6 & 1-P-B1 Farmers dig up transmission line & $0.155 E-01$ & 0.333 & 1.00 \\
\hline 7 & 1-P-B1 Power supply Auto-Mod \#9109 failure off & $0.12+E-01$ & 0.267 & 1.00 \\
\hline 8 & I-V-C1 Tank level module voltage high & $0.617 \mathrm{E}-02$ & 0.133 & 1.00 \\
\hline 8 & I-V-D2 Valve module contacts open & 0.617 E-02 & 0.133 & 1.00 \\
\hline 8 & I-P-D1 Pump switch module voltage high & $0.617 \mathrm{E}-02$ & 0.133 & 1.00 \\
\hline 8 & I-P-B1 Module \#514 voltage signal high & $0.617 \mathrm{E}-02$ & 0.133 & 1.00 \\
\hline 8 & I-P-B1 Module \#502 voltage signal high & 0.617 E-02 & 0.133 & 1.00 \\
\hline 8 & I-P-A1 PCW \#3 motor fails to function & $0.617 \mathrm{E}-02$ & 0.133 & 1.00 \\
\hline 8 & I-V-D2 TCW S-tank level rec card voltage high & 0.617 E-02 & 0.133 & 1.00 \\
\hline 8 & I-V-D1 Standpipe level module failure (on) & $0.617 E-02$ & 0.133 & $0.13 \mathrm{yr}$ \\
\hline 8 & I-V-Dl Tank level alarm module failure (on) & 0.617 E-02 & 0.133 & $0.13 \mathrm{yr}$ \\
\hline 9 & 1-P-A2 Pressure switch out of tolerance & $0.311 E-02$ & $0.670 \mathrm{E}-01$ & $0.13 \mathrm{yr}$ \\
\hline 9 & 1-P-Al Pressure switch out of tolerance & $0.311 \mathrm{E} \cdot 02$ & $0.670 \mathrm{E}-01$ & $0.13 \mathrm{yr}$ \\
\hline 9 & 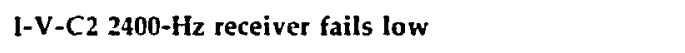 & $0.311 \mathrm{E}-02$ & $0.670 \mathrm{E}-01$ & 1.00 \\
\hline 9 & I-V-C2 Valve stem failure & $0.311 \mathrm{E}-02$ & $0.670 \mathrm{E}-01$ & 1.00 \\
\hline 9 & I-V-CI Residual magnetism relay CRI & $0311 \mathrm{E}-02$ & $0.670 E-01$ & 1.00 \\
\hline 9 & I-V-D2 Relay coil CR7 open circuit & $0.311 \mathrm{E}-02$ & $0.670 \mathrm{E}-01$ & 1.00 \\
\hline 9 & I-V-C1 Open circuit relay CR1 & $0.311 \mathrm{E}-02$ & $0.670 \mathrm{E}-01$ & 1.00 \\
\hline 9 & I-V-D1 CR 5-3 contacts close & $0.311 \mathrm{~F}-02$ & $0.670 \mathrm{E}-01$ & 1.00 \\
\hline 9 & I-P-D1 TSCW level receiver voltage high & $0.311 E-02$ & $0.670 \mathrm{E}-01$ & 1.00 \\
\hline 9 & I-P-A1 Lead pump receiver failure off & $0.311 \mathrm{E}-02$ & $0.670 \mathrm{E}-01$ & 1.00 \\
\hline 9 & I-V-C1 Level transmitter fails low & $0.311 \mathrm{E}-02$ & $0.670 E-01$ & 1.00 \\
\hline 9 & 1-P-D1 CR3-2 contacts transfer open & $0.311 \mathrm{E}-02$ & $0.670 \mathrm{E}-01$ & 1.00 \\
\hline 9 & I-P-D1 CR1A-1 contacts transfer open & $0.311 \mathrm{E}-02$ & $0.670 \mathrm{E}-01$ & 1.00 \\
\hline 9 & I-V-C2 Agastat TDR-4 contacts transfer open & $0.311 \mathrm{E}-02$ & $0.670 \mathrm{E}-01$ & 1.00 \\
\hline 9 & I-V-D2 Flow valve selector switch opens & 0.311 E-02 & $0.670 E-01$ & 1.00 \\
\hline 9 & I-P-A1 PSR6 contacts transfer open & 0.311 E-02 & $0.670 \mathrm{E}-01$ & 1.00 \\
\hline 9 & I-V-D1 CR2A-1 contacts close & $0.311 E-02$ & $0.670-01$ & 1.00 \\
\hline
\end{tabular}


Table 16. Ranking of initiating events (the conditions are listed below).

\begin{tabular}{|c|c|c|c|c|}
\hline \multirow[b]{2}{*}{ Rank } & $\because$ & $\begin{array}{c}\text { rage tank and } \\
2847.6 \text { Hou } \\
1.0367 \text { Hour }\end{array}$ & $\begin{array}{l}\text { etection } \\
2506 \text { years } \\
197 \text { E-01 days. }\end{array}$ & \\
\hline & Basic event description & Importance & $\begin{array}{c}\text { Failure rate } \\
\text { per year }\end{array}$ & $\begin{array}{c}\text { Mean fault duration } \\
\text { (hr) }\end{array}$ \\
\hline 1 & I-V-D2 Noise on line to control valve transmitter & 0.325 & 1.000 & 1.000 \\
\hline 2 & I-V-C1 PG\&E power failure & 0.163 & 5.00 & 1.000 \\
\hline 3 & I-V-C1 High resistance WLT \#1 transducer & 0.130 & 0.400 & 1.000 \\
\hline 4 & I-V-D2 Valve module cuntacts open & $0.432 \mathrm{E}-01$ & 0.133 & 1.000 \\
\hline 4 & I-V-CI Tank level module voltage high & $0.432 \mathrm{E}-01$ & 0.133 & 1.000 \\
\hline 4 & I-V-D2 TCW S-tank level rec card voltage high & $0.432 \mathrm{E}-01$ & 0.133 & 1.000 \\
\hline $\mathbf{5}$ & I-V-C1 Level transmitter fails low & $0.218 \mathrm{E}-01$ & $0.670 \mathrm{E}-01$ & 1.000 \\
\hline 5 & I-V-D2 TCW storage tank level receiver high & $0.218 \mathrm{E}-01$ & 0.670 E-01 & 1.000 \\
\hline 5 & 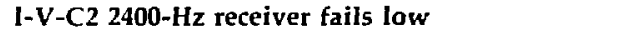 & $0.218 E-01$ & 0.670 E-01 & 1.000 \\
\hline 5 & I-V-C1 Open circuit relay CR1 & $0.218 \mathrm{E}-01$ & 0.670 E-01 & 1.000 \\
\hline 5 & I-V-C1 Residual magnetism reIay CRI & $0.218 \mathrm{E}-01$ & $0.670 \mathrm{E}-01$ & 1.000 \\
\hline $\mathbf{5}$ & I-V-D2 Relay coil CR7 open circuit & $0.218 \mathrm{E}-01$ & $0.670 \mathrm{E}-01$ & 1.000 \\
\hline $\mathbf{5}$ & I-V-C2 Agastat TDR-4 contact transfer open & $0.218 \mathrm{E}-01$ & $0.670 \mathrm{E}-01$ & 1.000 \\
\hline $\mathbf{5}$ & I-V-D2 Flow valve selector switch opens & $0.218 \mathrm{E}-01$ & $0.670 \mathrm{E}-01$ & 1.000 \\
\hline 5 & I-V-C2 Valve selector switch contacts open & $0.218 \mathrm{E}-01$ & 0.670 E-01 & 1.000 \\
\hline $\mathbf{5}$ & I-V-C2 Valve stem failure & $0.218 \mathrm{E}-01$ & 0.670 E-01 & 1.000 \\
\hline 5 & I-V-D2 Valve transmitter fails low & 0.218 E-01 & 0.670 E-01 & 1.000 \\
\hline 6 & I-V-D1 Close all valve transmitter failure on & $0.921 \mathrm{E}-02$ & 1.000 & 1.000 \\
\hline 7 & I-V-C1 Storage tank(s) valved out & 0.632 E-03 & 0.670 E-01 & 1.000 \\
\hline 8 & 1-P-C1 Standpipe \#2 valved out & 0.617 E-03 & 0.670 E-01 & 1.000 \\
\hline $\mathbf{s}$ & I-V-D1 CR5-3 contacts close & 0.617 E-03 & 0.670 E-01 & 1.000 \\
\hline 8 & I-V-D1 CR2A-1 contacts close & 0.617 E-03 & 0.670 E-01 & 1.000 \\
\hline 9 & I-P-D1 Noise on line from standpipe to Bldg. 511 & 0.958 E-04 & 1.000 & 1.000 \\
\hline
\end{tabular}

failure of control devices on the tank level feedback loop which would go undetected in Bldg. 511.

Table 17 ranks the enabling events. We see that failure of components in the backup power supply system, i.e., the inverter, battery, and battery charger are dominant enabling events. The next most important enabling event is failure of the operator in Bldg. 511 to respond to a low-level tank alarm. We assign a probability of 0.01 for this event, which is consistent with data given by Swain and Guttman. ${ }^{15}$ Table 17 also ranks the most important min-cut sets. These min-cut sets include the important initiating and enabling events described above. 
Table 17. Ranking of enabling events.

Insufficient level in storage tank and no detection

Enabler (sequential contributory) basic event importance (measure of interval reliability)

\begin{tabular}{|c|c|c|c|c|}
\hline Rank & Basic event description & Importance & $\begin{array}{c}\text { Failure rate } \\
\text { per year }\end{array}$ & $\begin{array}{c}\text { Mean fault duration } \\
\text { (yr) }\end{array}$ \\
\hline 1 & Inverter failure storage tank & $0.564 \mathrm{E}-01$ & 0.267 & 0.130 \\
\hline 1 & Battery failure at storage tank & 0.564 E-01 & 0.267 & 0.130 \\
\hline 1 & Battery charger failure storage tank & $0.564 \mathrm{E}-01$ & 0.267 & 0.130 \\
\hline 2 & No operator response to low storage tank level & $0.433 \mathrm{E}-02$ & - & $0.100 \mathrm{E}-01$ \\
\hline 3 & Relay coil CR6-1 open circuit & $0.377 \mathrm{E}-02$ & $0.670 \mathrm{E}-01$ & 0.130 \\
\hline 3 & Storage alarm module inactive & $0.377 \mathrm{E}-02$ & $0.670 \mathrm{E}-01$ & 0.130 \\
\hline 4 & No operator response to low standpipe level & $0.557 \mathrm{E}-03$ & - & 0.100 E-01 \\
\hline 5 & Red light indicator low storage-tank burned out & 0.522 E-03 & 0.267 & 0.130 \\
\hline 5 & Tank low-level alarm inactive & $0.522 \mathrm{E}-03$ & 0.267 & 0.130 \\
\hline 6 & TDR1A-1 contacts fail to close & 0.490 E-04 & 1.000 & 0.130 \\
\hline 6 & TDR3A-1 contacts fail to close & $0.490 \mathrm{E}-04$ & 1.000 & 0.130 \\
\hline 7 & Red light indicating low standpipe level burned & $0.170 \mathrm{E}-04$ & 0.267 & 0.130 \\
\hline 7 & Standpipe low-level alarm inactive & $0.170 \mathrm{E}-04$ & $0.670 \mathrm{E}-01$ & 0.130 \\
\hline 8 & Tank selector switch in the wrong position & $0.149 \mathrm{E}-04$ & 6.00 & $1.000 \mathrm{hr}$ \\
\hline 9 & No operator response to high tank level & $0.120 \mathrm{E}-04$ & - & $0.100 \mathrm{E}-01$ \\
\hline 10 & 905-Hz OT-30 transmitter inactive & $0.328 \mathrm{E}-05$ & $0.670 \mathrm{E}-01$ & 0.130 \\
\hline 10 & FR3-2 contacts fail to close & 0.328 E-05 & $0.670 \mathrm{E}-01$ & 0.130 \\
\hline 10 & 1325 OT-30 transmitter failure & 0.328 E-05 & $0.670 \mathrm{E}-01$ & 0.130 \\
\hline 10 & FR3-2 contacts fail to close & 0.328 E-05 & $0.670 \mathrm{E}-01$ & 0.130 \\
\hline 11 & Red light indicating high tank level burned out & 0.368 E-06 & 0.267 & 0.130 \\
\hline 11 & Tank high level alarm inactive & $0.368 \mathrm{E}-06$ & $0.670 \mathrm{E}-01$ & 0.130 \\
\hline 12 & PCW \#1 light burned out & 0.114 E-06 & 0.267 & 0.130 \\
\hline 12 & PCW \#3 light burned out & 0.114 E-06 & 0.267 & 0.130 \\
\hline 12 & PCW \#3 alarm failure (off) & 0.114 E-06 & $0.670 \mathrm{E}-01$ & 0.130 \\
\hline 12 & PCW \#1 alarm failure & $0.114 \mathrm{E}-06$ & 0.670 E-01 & 0.130 \\
\hline
\end{tabular}

\section{Acknowledgments}

The authors thank and appreciate the contributions of Dr. Arnold A. Weintraub for his support and encouragement throughout the execution of this project. His criticism and direction were instrumental in guiding our research to positive progress. 


\section{References}

1. H. K. Hasegawa, N. J. Alvares, A. E. Lipska-Quinn, D. G. Beason, S. J. Priante, and K. L. Foote, Frre Protection Research for Energy Technology Projects: FY 82 Year-End Report, Lawrence Livermore National Laboratory, Livermore, California, UCRL-53179-82 (1983).

2. H. K. Hasegawa, N. J. Alvares, A. E. Lipska-Quinn, D. G. Beason. K. L. Foote, and S. J. Priante, Fire Protiction Re'search for Encryy Technology Projects: FY 81 Year-End Report, Law'rence Livermore National Laboratory, Livermore, California, UCRI -53179-81 (1982).

3. H. K. Hasegawa, N. J. Alvares, A. E. Lipska, H. W. Ford, S. Priante, and D. G. Beason, Fire Protection Risearch for Energy Technology Projects: FY 80 Year-End Report. Lawrence Livermore National Laboratory, Livermore, California, UCRL-53179 (1981).

4. H. K. Hasegawa, N. J. Alvares, A. E. Lipska, H. W. Ford, and D. G. Beason, Fire Protection Research for Encryy Technology Projects: FY 79 Y'ar-End Repori, Lawrence Livermore National Laboratory, Livermore, California, UCID-18902 (1981).

5. N. J. Alvares, K. L. Foote, and P. J. Pagni, Forced-Ventilated Enclosurc Fires, Lawrence Livermore National Laboratory, Livermore, California, UCRL-89615 (1984).

6. J. R. Lawson and W. J. Parker, Development of an Ezse-of-lg,';' 'n Test Using a Flame Exposure, National Bureau of Standards, Washington, D.C., NBSIR 82-2503 (June, 1982).

7. J. C. Siegle, L. T. Muus, T. Lin, and H. A. Larsen, "The Molecular Structure of Perfluorocarbon Polymers II: Pyrolysis of Poly (tetrafluoroethylene)," I. Polum. Sci. A2:391 (1964).

8. H. H. G. Jellinek and H. Kachi, "Thermal Degradation of Poly (tetrafluoroethylene) in a Closed System," Makromol. Chem. 85:1 (1965).

9. L. A. Errede, "The Application of Simple Equations for Calculating Bond Dissociation Energies to Thermal Degradation of Fluorocarbons," I. of Org. Ch'm. 27:3425 (1962).

10. A. J. Lovinger and D. J. Freed, "Inhomogeneous Thermal Degradation of Poly (vinylidene fluoride) Crystallized from Melt," Macromolecules 13:3425 (1980).

11. H. E. Lambert, The Digraph-Fault Tree Methodology and lts Ulse in Transportation Risk Analysis, Tera Corporation, Berkeley, California.

12. C. Dunglinson and H. E. Lambert, "Interval Reliability for Initiating and Enabling Events," IEEE Transactions on Roliability, R-32, 2 (1983).

13. H. E. Lambert, J. J. Lim, and F. N. G. Filman, A Digraph-Fault Tree Methodology for the Assessment of Material Contrul Systims, Lawrence Livermore National Laboratory, Livermore, California, UCRL52170 (1979).

14. H. E. Lambert, IMP(IRTANCE: The IMPORTANCE Computer Code, lawrence Livermore National Laboratory, Livermore, California, UCRL-79269 (1977).

15. Swain and Guttman, Handhook of Human Reliability Analysis with Emphasis on Nuclear Power Plant Applications, Nuclear Regulatory Commission, Washington, D.C., NUREG-1278 (1983). 


\title{
Appendix $\mathbf{A}$ Forced-Ventilation Enclosure Fires
}

\begin{abstract}
Twenty-seven forced ventilation fire experiments were conducted in the LLNL fire test cell. A wide variety of fuels, ventilation rates and fire strengths were included. Experimental results revealed that "quasi-steady-state" was not reached until approximately 2000 sec after ignition. It was found that $80 \% \pm 5 \%$ of the heat produced by the fire was deposited in the enclosure walls. Twice the stoichiometric ventilation was required to insure complete combustion of the provided fuel. Selected data was compared with predictions from several computer models and the attributes and diffculties of each are discussed.
\end{abstract}

\section{Introduction}

The compartment fire experiments described here were conducted in the Lawrence Livermore National Laboratory Fire Test Cell to assess the behavior of fire and fire products where enclosure ventilation is provided by an air-extraction system (Alvares, et al., 1981 and 1982). Such systems are standard in modern laboratory and power-generating facilities (Cleary, W. M., 1979). The 27 tests described here are part of an ongoing series of experimental fires begun in July 1981. The fires, located on the floor on the center line of the test cell, were either naturally burning pool fires or analogue pool fires where the fuel (either gas or liquid) was metered into a burner or pan. The purpose of the analogue pool fires was to control the fire strength and thereby to assess interaction between fire strength and ventilation rate. Designed experimental conditions ran the gamut from fully ventilated to severely ventilation-limited fires.

Two requirements motivated these experiments: (1) to develop insight and experience with characteristics of fires in extraction-ventilated enclosures, and (2) to produce quantitative data to evaluate current mathematical models modified to fit the extraction-ventilation mode. It is intended to use validated portions of the tested models as the initial component of a procedure to predict fire risk in large research and fabrication enclosures.

\section{Instrumentation}

Figure A-1 is an artistic conception of enclosure geometry and Fig. A-2 is a detail of the extraction ventilation system. Clean air is introduced along the floor of the test cell, and combustion products are pulled out near the top of the cell by an axial fan. Extraction rate is controlled by a butterfly valve upstream of the fan. Exit gas flowrate from the test cell is measured by a sharp-edge orifice, and inlet flow rate is measured using a calibrated vane anemometer. Table A-1 gives some pertinent properties of the enclosure.

Table A-2 lists experiments conducted during the FY 1982 test series. The first five columns describe the tests done: fuel, type of fire, heat release rate, and initial forced ventilation rate in the exit duct. "Fire type" refers to the method of fuel control and fuel phase.

In the tests designated "gas," bottled methane metered by critical orifice and in-line turbine meter was conveyed to a 0.28 -m-diam rock-filled pan on the floor of the test cell. Gas entering the pan at the bottom becomes distributed uniformly through the rock bed as it flows to the rock bed surface. This burner was intended to be a pool fire analog. Unfortunately, the burner diameter was too small and at high fire strengths (i.e., high fuel-flow rates) the burner flame took on characteristics of a momentum jet rather than the intended bouyant plume. This complicated analyses of these methane-fueled fires. 


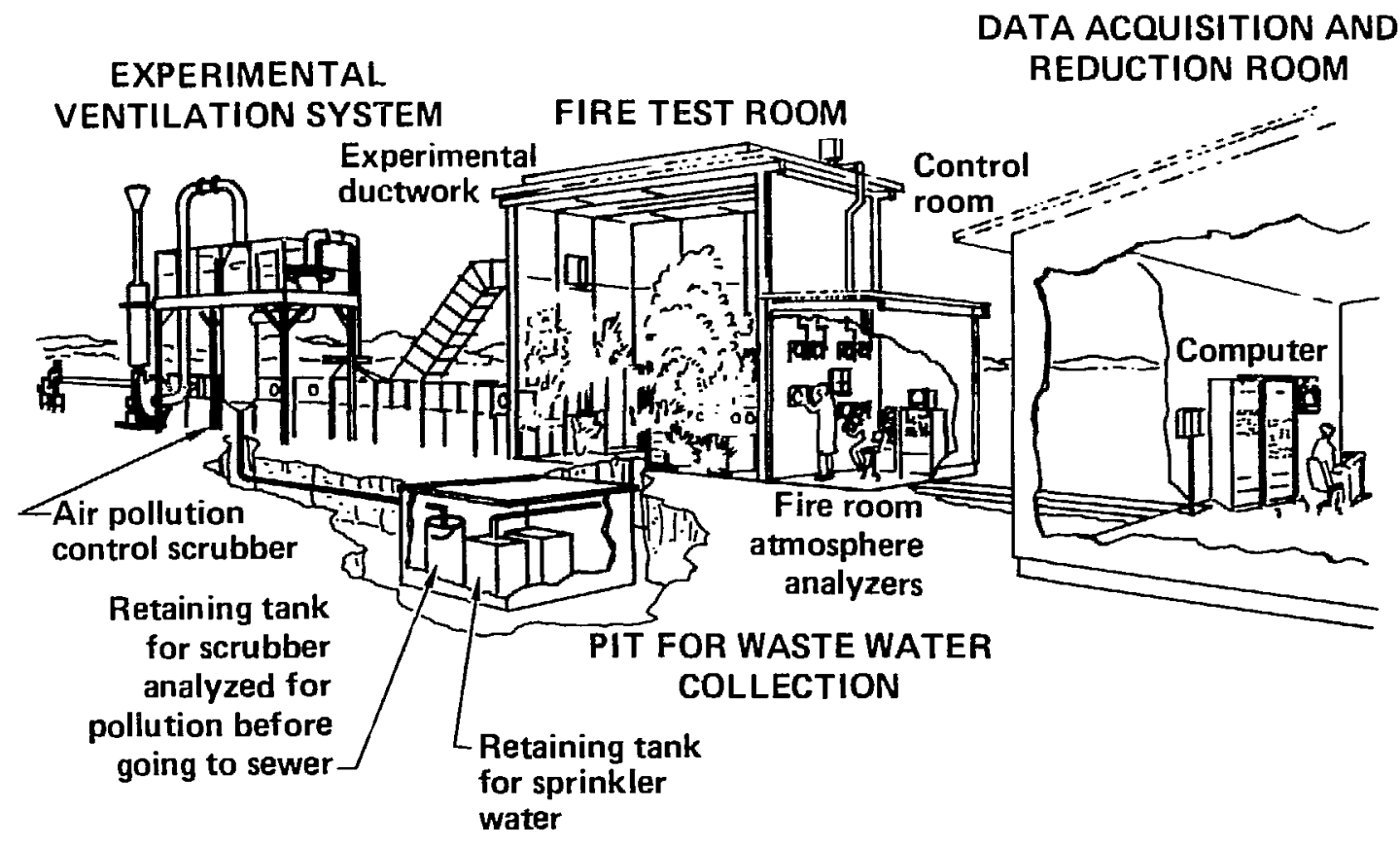

Figure A-1. Artist's conception of LLNL test cell geometry.

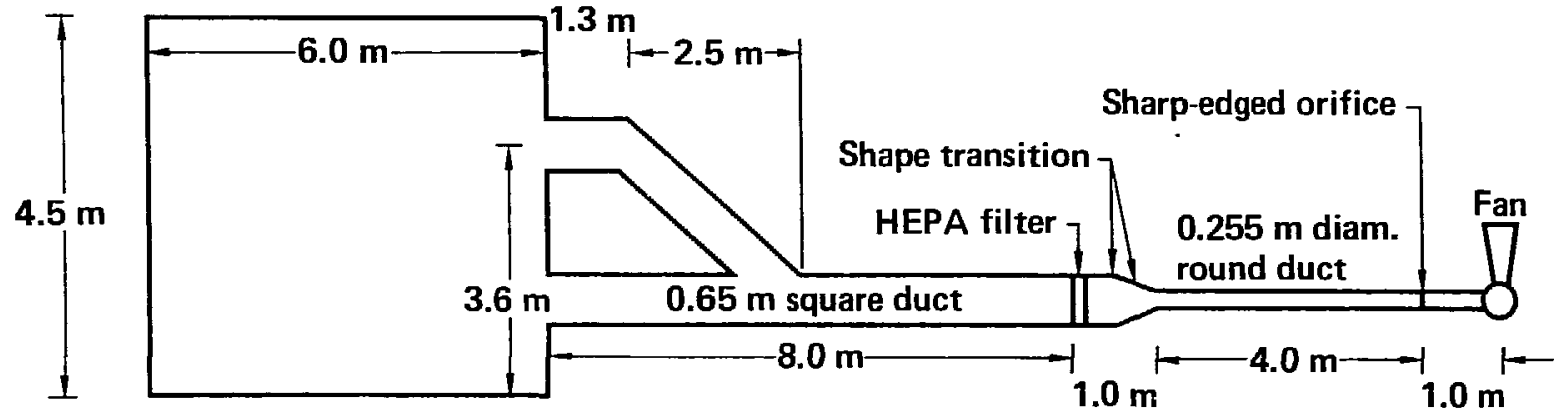

Figure A-2. Detail of LLNL extraction ventilation system.

Table A-1. 1982 LLNL test-cell geometry information.

1. The burn room was $4.5 \mathrm{~m}$ high, $4.0 \mathrm{~m}$ wide, and $6.0 \mathrm{~m}$ long.

2. The exit opening $(65 \mathrm{~cm} \times 65 \mathrm{~cm})$ was on the vertical centerline of the west wall $(4.0 \mathrm{~m}$ wide $\times 4.5 \mathrm{~m}$ high), with its center $3.6 \mathrm{~m}$ above the floor.

3. The inlet opening consisted of four horizontal rectangles $(0.5 \mathrm{~m}$ long $\times 0.12 \mathrm{~m}$ high) with horizontal centerlines $0.1 \mathrm{~m}$ above the floor.

4. For radiation calculations, the walls can be assumed to be completely black.

5. The walls, floor and ceiling consist of a $10-\mathrm{cm}$ thick $\mathrm{Al}_{2} \mathrm{O}_{3}-\mathrm{S}_{1} \mathrm{O}_{2}$ refractory with the following estimated properties:

\begin{tabular}{lcc} 
& Walls & Ceiling \\
\cline { 2 - 2 }$\left(\mathbf{k g} / \mathrm{m}^{3}\right)$ & 1440 & 1920 \\
$\mathrm{k}\left(\mathrm{W} / \mathrm{m}^{\circ} \mathbf{k}\right)$ & 0.39 & 0.63 \\
$\mathrm{c}\left(\mathrm{J} / \mathrm{kg} \mathbf{k}^{\circ}\right)$ & 1000 & 1000
\end{tabular}


Table A-2. 1982 Fire model test data.

\begin{tabular}{|c|c|c|c|c|c|c|c|c|c|c|c|c|}
\hline Test & $\underset{\mathbf{k W}}{\mathbf{O}}$ & $\begin{array}{c}\dot{\mathrm{v}} \\
1 / \mathrm{s}\end{array}$ & $\begin{array}{c}\text { Fuel } \\
\text { formula }\end{array}$ & $\begin{array}{l}\text { Fire } \\
\text { type }\end{array}$ & $\begin{array}{c}\text { Steckler } \\
\text { layer } \\
\text { height (m) }\end{array}$ & $\begin{array}{c}\text { Exit } \\
\text { gas } \\
\text { temp }^{\circ} \mathrm{C}\end{array}$ & $\begin{array}{c}\text { Zone } 6 \\
\text { wall } \\
\text { temp }{ }^{\circ} \mathrm{C}\end{array}$ & $\begin{array}{c}\text { \% Heat } \\
\text { loss } \\
\text { to walls }\end{array}$ & $\underset{\substack{\mathrm{O}_{2} \\
\text { consumed } \\
(\mathrm{g} / \mathrm{s})}}{ }$ & $\begin{array}{c}\mathrm{CO}_{2} \\
(\mathrm{~g} / \mathrm{s})\end{array}$ & $\begin{array}{c}\mathrm{CO} \\
(\mathrm{g} / \mathrm{s})\end{array}$ & $\begin{array}{l}\mathrm{CH}_{4} \\
(\mathrm{~g} / \mathrm{s})\end{array}$ \\
\hline MOD3 & 60 & 100 & $\mathrm{CH}_{4}$ & Burner & 1.53 & 100 & 80 & - & 4.5 & 4.2 & - & - \\
\hline MOD2 & 55 & 500 & $\mathrm{CH}_{4}$ & Burner & 1.77 & 90 & 65 & 67 & 5.0 & 4.9 & - & - \\
\hline MOD10 & 100 & 100 & $\mathrm{C}_{3} \mathrm{H}_{8} \mathrm{O}$ & Spray & 1.27 & 100 & 80 & 87 & 2.4 & 5.8 & - & - \\
\hline MOD11 & 100 & 500 & $\mathrm{C}_{3} \mathrm{H}_{8} \mathrm{O}$ & Spray & 1.65 & 90 & 60 & 62 & 6.1 & 9.8 & - & - \\
\hline MOD11A & 100 & 500 & $\mathrm{C}_{3} \mathrm{H}_{8} \mathrm{O}$ & Spray & 1.48 & 100 & 80 & 64 & 3.0 & 8.7 & - & - \\
\hline MOD1 & 135 & 250 & $\mathrm{CH}_{4}$ & Burner & $1.45^{43 !}$ & 130 & 90 & 84 & $8.7^{(2)}$ & 8.7 & - & - \\
\hline MOD7 & 135 & 250 & $\mathrm{CH}_{4}$ & Burner & 1.24 & 140 & 105 & 82 & 9.3 & 9.6 & - & - \\
\hline MOD24 & 200 & 110 & $\mathrm{C}_{\mathrm{g}} \mathrm{H}_{1 \mathrm{~s}}$ & Spray & 1.05 & 150 & $1 \div 5^{(b)}$ & 83 & 10.3 & 10.5 & 0.3 & 0.07 \\
\hline MOD25 & 200 & 90 & $\mathrm{C}_{3} \mathrm{H}_{8} \mathrm{O}$ & Spray & 1.24 & 160 & $160^{(b)}$ & 86 & 14.2 & 12.5 & 1.7 & 0.03 \\
\hline MOD4 & 230 & 100 & $\mathrm{CH}_{4}$ & Burner & $1.36^{(3)}$ & 170 & 150 & 95 & 13.8 & 10.7 & 1.3 & 0.3 \\
\hline MOD23 & 400 & 130 & $\mathrm{C}_{8} \mathrm{H}_{1 \mathrm{~s}}$ & Spray & 1.12 & 180 & 150 & 83 & 15.9 & 13.1 & - & 0.66 \\
\hline MOD26 & 400 & 100 & $\mathrm{C}_{3} \mathrm{H}_{8} \mathrm{O}$ & Spray & 1.11 & 180 & $180^{\prime b \prime}$ & - & 17.8 & 14.7 & 5.3 & 0.37 \\
\hline MOD6 & 460 & 100 & $\mathrm{CH}_{4}$ & Burner & $1.39^{(d)}$ & 200 & 180 & - & $12.4^{(2)}$ & 9.9 & 1.5 & 0.58 \\
\hline MOD6A & 470 & 100 & $\mathrm{CH}_{4}$ & Burner & $1.39^{(3)}$ & 190 & 170 & - & $13.7^{(\Delta)}$ & 10.8 & 2.2 & 0.61 \\
\hline MOD27 & 400 & 250 & $\mathrm{C}_{3} \mathrm{H}_{8} \mathrm{O}$ & Spray & 1.10 & 220 & $220^{(b)}$ & 95 & 23.6 & 21.4 & 2.9 & 0.02 \\
\hline MOD27A & 400 & 250 & $\mathrm{C}_{3} \mathrm{H}_{8} \mathrm{O}$ & Spray & 1.02 & 210 & $200^{(b)}$ & 91 & 20.7 & 23.3 & - & 0.14 \\
\hline MOD27B & 400 & 250 & $\mathrm{C}_{3} \mathrm{H}_{8} \mathrm{O}$ & Spray & 1.03 & 205 & $185^{(b)}$ & 89 & 24.9 & 26.4 & - & 0.11 \\
\hline MOD8 & 400 & 500 & $\mathrm{C}_{3} \mathrm{H}_{8} \mathrm{O}$ & Spray & 1.24 & 200 & 160 & 83 & 29.0 & 30.3 & - & - \\
\hline MOD13 & 400 & 500 & $\mathrm{C}_{3} \mathrm{H}_{8} \mathrm{O}$ & Spray & 1.12 & 230 & 180 & 79 & 20.9 & 31.5 & - & - \\
\hline MOD14 & 400 & 500 & $\mathrm{C}_{8} \mathrm{H}_{18}$ & Spray & 1.04 & 200 & 150 & 79 & $12.4^{(\mathrm{c})}$ & $27.1^{|c|}$ & $-(\alpha)$ & 0.04 \\
\hline MOD14A & 400 & 500 & $\mathrm{C}_{8} \mathrm{H}_{18}$ & Spray & 0.90 & 200 & 150 & 68 & $13.9^{(c)}$ & $23.4^{1(1)}$ & $-(0)$ & 0.04 \\
\hline MOD5 & 455 & 500 & $\mathrm{CH}_{4}$ & Burner & $1.44^{(\lambda)}$ & 280 & 210 & 83 & 36.0 & 32.6 & - & 0.04 \\
\hline MOD9 & 800 & 500 & $\mathrm{C}_{3} \mathrm{H}_{8} \mathrm{O}$ & Spray & 1.10 & 280 & 225 & 88 & 55.2 & 50.5 & 13.2 & 2.0 \\
\hline MCD9A & 800 & 500 & $\mathrm{C}_{3} \mathrm{H}_{8} \mathrm{O}$ & Spray & 1.47 & 280 & 220 & 87 & 44.8 & 46.9 & 4.3 & 1.9 \\
\hline MOD15 & 800 & 500 & $\mathrm{C}_{\mathrm{S}} \mathrm{H}_{18}$ & Spray & 1.11 & 255 & 200 & 82 & $17.0^{(6)}$ & $29.4^{(c)}$ & -101 & 1.7 \\
\hline MOD12 & 800 & 100 & $\mathrm{C}_{3} \mathrm{H}_{8} \mathrm{O}$ & Spray & $-(3)$ & - & - & - & - & - & - & - \\
\hline MOD16 & 800 & 100 & $\mathrm{C}_{8} \mathrm{H}_{18}$ & Spray & $-^{(a)}$ & - & - & - & - & - & - & - \\
\hline MOD17 & 600 & 500 & $\mathrm{C}_{3} \mathrm{H}_{8} \mathrm{O}$ & Pool & 1.08 & 250 & 195 & 63 & $5.6^{(c)}$ & $6.8^{(c)}$ & $2.2^{1{ }^{\prime \prime}}$ & - \\
\hline MOD18 & 400 & 100 & $\mathrm{C}_{3} \mathrm{H}_{\mathrm{B}} \mathrm{O}$ & Pool & 1.12 & 160 & 150 & 83 & $9.3^{(c)}$ & $7.6^{(0)}$ & $4.3^{(0)}$ & - \\
\hline MOD19 & 1100 & 500 & $\mathrm{C}_{8} \mathrm{H}_{\mathrm{IH}}$ & Pool & 1.09 & 255 & 200 & - & 36.3 & 29.0 & 9.9 & - \\
\hline
\end{tabular}

\footnotetext{
(a) Equilibrium not reached.

(b) Test run after polystyrene.

ic' Leak in gas analysis line.
}

rotometer to an opposed jet nozzle located in the center of a $0.91-\mathrm{m}$-diam steel pan with a $15-\mathrm{cm}$ lip on the floor of the test cell. Liquid from the nozzle is sprayed on a plane normal to the orifice axes with a uniform radial distribution. Ignition is by a remotely energized electric arc. The atomized spray quickly evaporates and burns before it contacts pan surfaces; and the resulting fire has every appearance of a natural pool fire. Figure A-3, plates "a" through "d," show photographs of the opposed jet nozzle, the pan with jet installed, the opposed jet nozzle spray pattern, and the resulting fire.

For tests designated as "pool," approximately 40 liters of liquid fuel were placed in the $0.91-\mathrm{m}$ steel pan. The intial fuel level came to $7 \mathrm{~cm}$ from the top of the $15-\mathrm{cm}$-high wall. The effects of the pan walls on the fuel-burning rate become asymptotic for lip heights greater than $7 \mathrm{~cm}$ for this size pool (i.e., $1 / \mathrm{d} \geq$ 0.08), (Orloff, 1981). The mass pyrolysis rate was determined using a calibrated load cell.

Instrumentation of the enclosure and ventilation circuits was extensive and consisted of gas and surface thermocouples, calorimeters, radiometers, combustion gas and oxygen detectors, fuel and ventilation-flow sensors, and a video camera for recording the fire shape. Data were recorded and reduced on a PDP-11 computer. Table A-3 summarizes sensor and instrumentation parameters. Previous work (Alvares, et al., 1982) indicate that the majority of energy produced by fire (up to $80 \%$ ) is absorbed by the enclosure surfaces. To confirm this finding and assess the distribution of the surface energy deposition, 23 thermncouples were installed on test cell surfaces in the array displayed in Fig. A-4. These thermocouples were simply pressed onto the Kastolite surface and held there with spring tension. This distribution was dcsigned assuming a symmetrical energy source field. 

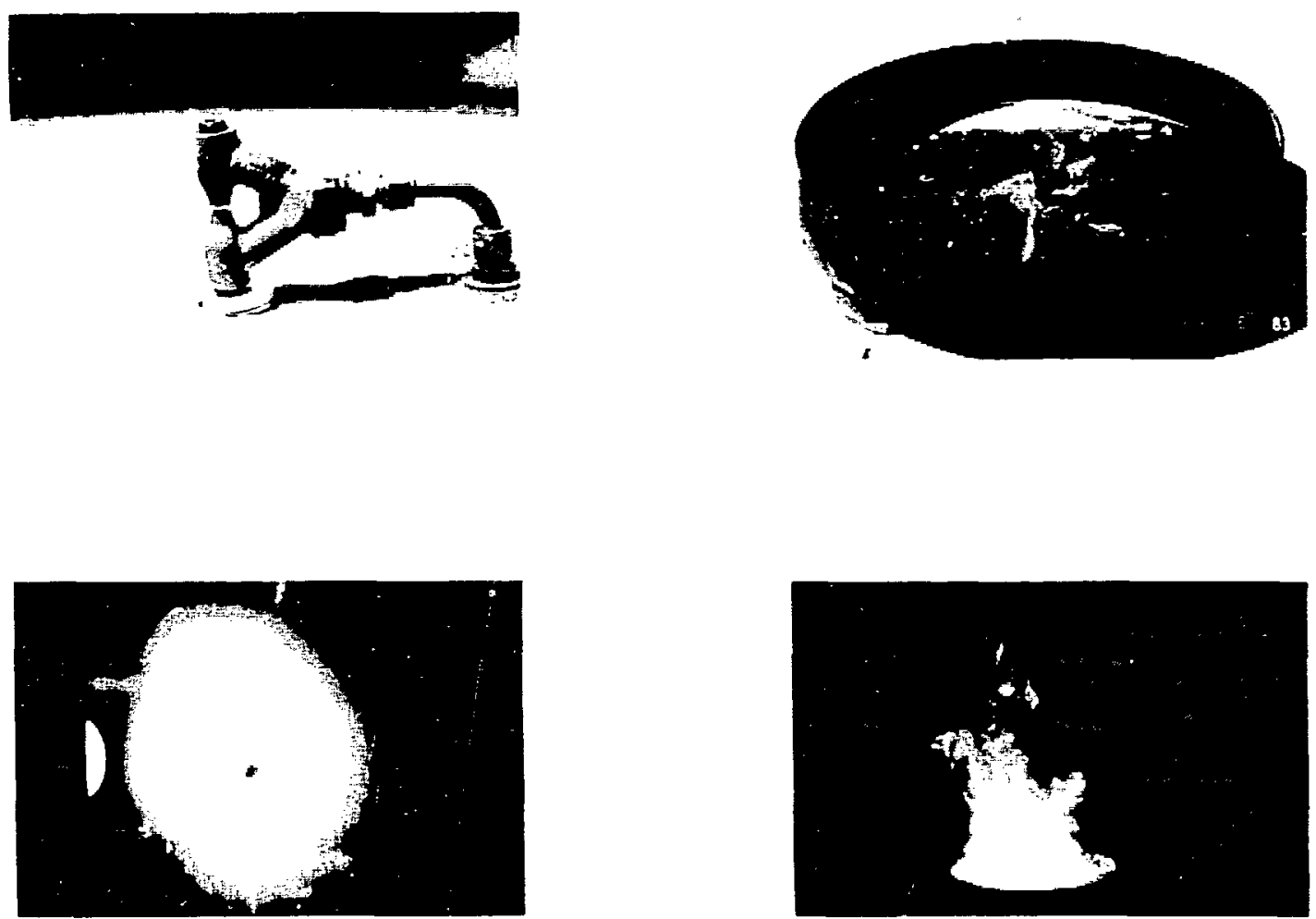

Figure A-3. Photographs of spray injection system.

For fires designated "spray," liquid fuel from a pressurized reservoir flows through a calibrated

The standard experimental procedure depended on the fuel involved. Essentially, ventilation and fuel flow rates were initially fixed, and pre-calibration of gas analyzers was done before the test cell was secured for the test. Then, five minutes of pre-ignition operation was allowed to insure stable instrument operation and to provide initial data values. Fuel flow and spark ignition were simultaneously initiated and data were recorded until quasi-steady-state conditions were reached.

\section{Experimental Results}

Figures A-5(a)-(d) are examples of data produced. MOD 27B was an isopropanol spray fire with the fire strength set to $400 \mathrm{~kW}$ and the ventilation rate maintained at $250 \mathrm{~L} / \mathrm{s}$. Figure $\mathrm{A}-5$ (a) contains typical gas and wall temperatures within the enclosure. Fig _res $A-5(b)-(d)$ show the consumption and production of combustion gases. (Note the relativley low temperatures, $<300^{\circ} \mathrm{C}$.) Figure $A-5(\mathrm{c})$ shows the inlet and outlet air flows.

One feature common to all tests is the appearance of a reversal inlet air flow spike, whereupon fire initiation the inlet flow is reduced, and sometimes, as in the case of Mod 27B, flow is reversed. The magnitude of this negative peak varies directly with fire strength. It is caused by the need to reduce the mass in the test cell to keep a constant energy per unit volume in the approximately constant pressure test cell. Also, at early times, the wall temperature may rise faster than the gas air temperature, indicating that initially direct thermal radiation heat transfer from the fire to the walls is important.

The exit air flow was adjusted to compensate for reduced flow because of wetting and plugging of a particulate filter located between the test cell and the extraction fan. All tests where the fire strength was greater than $400 \mathrm{~kW}$ had this problem, even though new filters were installed prior to each test. 
Table A-3. Instrumentation for 1982 fire model test series.

\begin{tabular}{|c|c|c|c|c|c|}
\hline Parameter & Instrument & Characteristics & Range & Accuracy & Stability \\
\hline $\begin{array}{l}\text { Ceiling and wall } \\
\text { temperature }\end{array}$ & $\begin{array}{l}\text { Exposed-bead } \\
\text { thermocouples }\end{array}$ & $\begin{array}{l}\text { Chrome-Alumel } \\
\text { Junction, American } \\
\text { wire gauge } 220.6+ \\
0.01 \mathrm{~mm} \text { bead }\end{array}$ & -18 to $1200^{\circ} \mathrm{C}$ & $\pm 1^{\circ} \mathrm{C}$ & \\
\hline $\begin{array}{l}\text { Compartment gas temp. } \\
\text { (horizontal array at } 2.1 \\
\text { and } 3.7 \mathrm{~m} \text { elevation) }\end{array}$ & $\begin{array}{l}\text { Shielded-bead } \\
\text { thermocouples }\end{array}$ & Same as above & -18 to $1200^{\circ} \mathrm{C}$ & $\pm 1^{\circ} \mathrm{C}$ & \\
\hline $\begin{array}{l}\text { Compartment gas temp. } \\
\text { (vertical rake) }\end{array}$ & $\begin{array}{l}\text { Exposed beads } \\
\text { shielded from plume } \\
\text { radiation by alumi- } \\
\text { num screen }\end{array}$ & $\begin{array}{l}\text { Chrome-Alumel } \\
\text { Junction, American } \\
\text { wire gauge } 36\end{array}$ & -18 to $1200^{\circ} \mathrm{C}$ & $\pm 1^{\circ} \mathrm{C}$ & \\
\hline Pressure & $\begin{array}{l}\text { One pitot tube at } 2.1 \\
\text { and } 3.7 \mathrm{~m} \text { elevations }\end{array}$ & & & & \\
\hline $\begin{array}{l}\text { Wall pressure just up- } \\
\text { stream of HEPA filter }\end{array}$ & $\begin{array}{l}\text { Validyne transducers, } \\
\text { Model P24 }\end{array}$ & & 0.01 to $3000 \mathrm{psi}$ & 0.05 psi & $\begin{array}{l} \pm 0.1 \text { psi for } D C \text { power } \\
\text { changes between } 22 \text { and } \\
35 \mathrm{~V}\end{array}$ \\
\hline Volumetric exhaust flux & $\begin{array}{l}\text { Wall pressure dif- } \\
\text { ferential across ori- } \\
\text { fice } 15.2 \text { m down- } \\
\text { stream of exhaust } \\
\text { inlet and downstream } \\
\text { of HEPA filter }\end{array}$ & & 0.01 to $3000 \mathrm{psi}$ & $0.05 \mathrm{psi}$ & Same as above \\
\hline Intake air velocity & $\begin{array}{l}\text { R. M. Young vane } \\
\text { anemometer }\end{array}$ & $\begin{array}{l}\text { Lower threshold } \\
0.2 \mathrm{~m} / \mathrm{s}\end{array}$ & $\begin{array}{l}\text { I to } 50 \mathrm{~m} / \mathrm{s} \text { linear } \\
\text { range }\end{array}$ & & \\
\hline \multirow[t]{2}{*}{$\mathrm{O}_{2}$ volume concentration } & Beckman Model 402 & $\begin{array}{l}\text { Exhaust sample } 3 / \mathrm{m} \\
\text { downstream duct in- } \\
\text { let, } 10 \% \text { full-scale re- } \\
\text { sponse in } 1 \mathrm{~s}\end{array}$ & $01025 \%$ & $\begin{array}{l}1 \text { to } 5 \% \text { ppm in clean } \\
\text { dir }\end{array}$ & $\begin{array}{l}\text { Recalibrated after eacl } \\
\text { test }\end{array}$ \\
\hline & $\begin{array}{l}\text { Beckman Model } \\
\text { OM-11 }\end{array}$ & $\begin{array}{l}90 \% \text { full-scale re- } \\
\text { sponse in } 80 \mathrm{~s}\end{array}$ & $010100 \%$ & $\begin{array}{l} \pm 5 \% \text { of measured } \\
\text { value }\end{array}$ & $\begin{array}{l}\text { Recalibrated after each } \\
\text { lest }\end{array}$ \\
\hline $\begin{array}{l}\mathrm{CO}, \text { volume } \\
\text { concentration }\end{array}$ & $\begin{array}{l}\text { Beckman Model } 864 \\
\text { exhaust air sample }\end{array}$ & $\begin{array}{l}90 \% \text { full-scale re- } \\
\text { sponse itl } 0.5 \mathrm{~s}\end{array}$ & 0 to $100 \%$ & $\pm 5 \%$ of measurement & $\begin{array}{l}\text { Recalibraled after each } \\
\text { test }\end{array}$ \\
\hline $\begin{array}{l}\text { CO volume } \\
\text { concentration }\end{array}$ & Beckman Model 864 & & & & \\
\hline $\begin{array}{l}\mathrm{H}_{1} \text { volume } \\
\text { concentration }\end{array}$ & $\begin{array}{l}\text { Beckman Model } 402 \\
\text { exhaust air sample }\end{array}$ & $\begin{array}{l}90 \% \text { full-scale re- } \\
\text { sponse in } 1 \mathrm{~s}\end{array}$ & 0 to $25 \%$ & $\pm 1 \%$ of ineasurement & $\pm 1 \%$ of full scale \\
\hline Liquid fuel flow & $\begin{array}{l}\text { Fisher-Porter fluw } \\
\text { rater } F P-1 / 2-27 /- \\
6-10 / 58\end{array}$ & $\begin{array}{l}\text { Calibrated at constant } \\
\text { pressure metering } \\
\text { volume change of de- } \\
\text { canted fuel }\end{array}$ & 0 to $2000 \mathrm{ml} / \mathrm{min}$ & $\begin{array}{l} \pm 2 \% \text { of measured } \\
\text { value al ambient } \\
\text { conditions }\end{array}$ & $0.5 \%$ of full scale \\
\hline Gas $\left(\mathrm{CH}_{4}\right)$ fuel flow & $\begin{array}{l}\text { Brooks full view ro- } \\
\text { lameter Model 1100- } \\
\text { 08 H12 G1B }\end{array}$ & $\begin{array}{l}\text { No gas pressure and } \\
\text { temperature } \\
\text { information }\end{array}$ & 0 to $200 \mathrm{ml} / \mathrm{min}$ & $\begin{array}{l}1 \% \text { of measured value } \\
\text { at ambient conditions }\end{array}$ & $0.5 \%$ of full scale \\
\hline $\begin{array}{l}\text { Total and radioactive } \\
\text { leat flux }\end{array}$ & $\begin{array}{l}\text { Hy-Cal calorimeter } \\
\text { and radiometer }\end{array}$ & $\begin{array}{l}\text { Placed in hol layer } \\
\text { outside fire plume }\end{array}$ & 0 to $300 \mathrm{BTU} / \mathrm{ft}^{2} \mathrm{~s}$ & $3 \%$ of measurement & $5 \%$ of fult scale \\
\hline
\end{tabular}




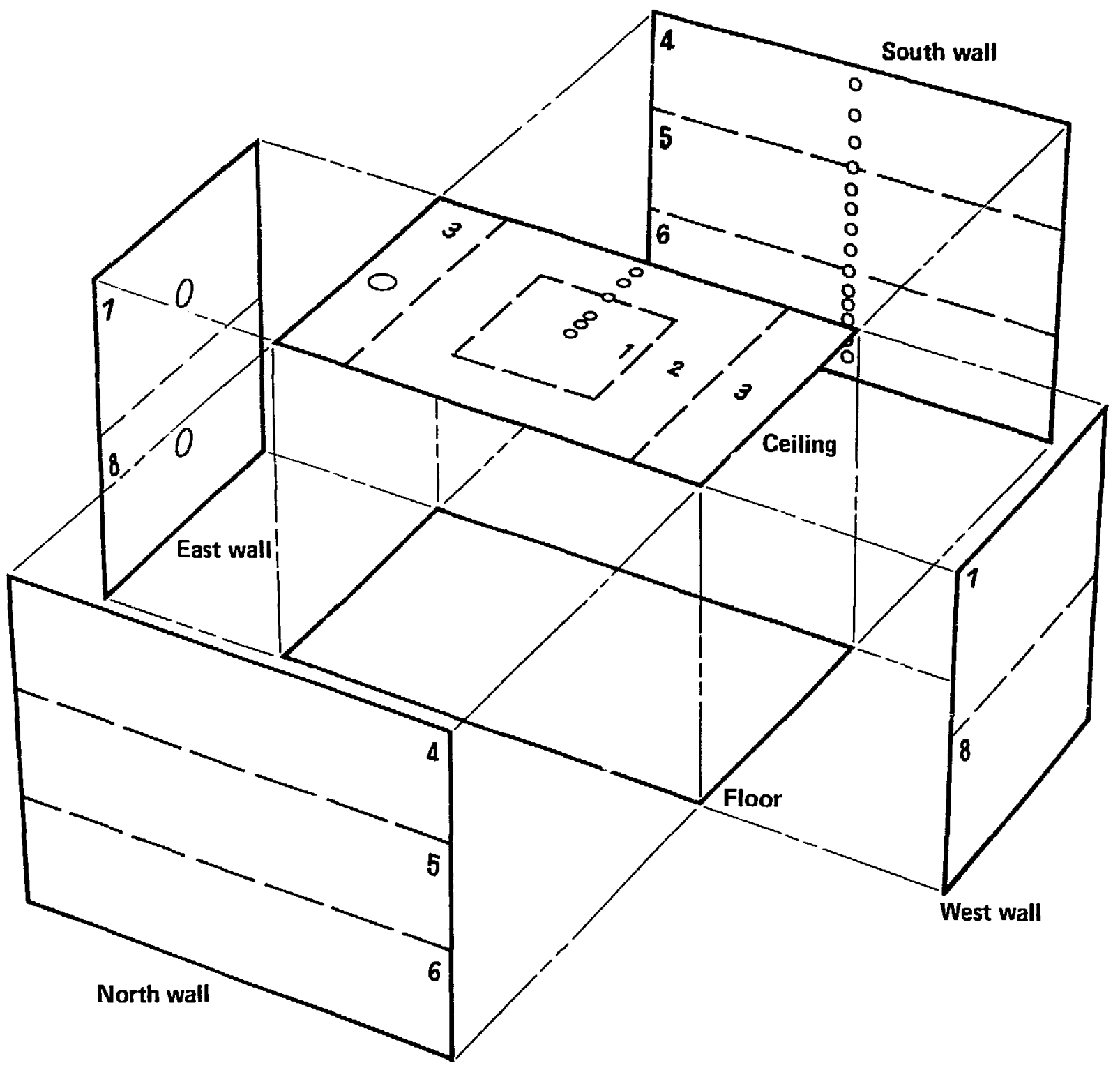

Figure A-4. Detail of wall thermocouple placement and wall zone areas used for Duhamel analysis.

MOD 27B is an example of an underventilated fire, where $\mathrm{CO}$ is produced and $\mathrm{CH}_{4}$ is found in test cell exhaust, Fig. A-5(d). To identify when to expect ventilation-controlled conditions, stoichiometric conditions were precalculated for ach fire strength and ventilation. In Fig. A-6, the solid line is the stoichiometric line for methane, which needs the most oxygen per gram of fuel. Fires below this line were expected to be under-ventilated and fires above this lina fully ventilated. This, however, was not the case. For these forced-ventilation tests, the inlet ventilation needed to be twice that of stoichiometry (the dashed line), or incomplete combustion occurred, as MOD 27B shows. This suggests that air entrained by the fire does not completely react with fuel gases in the reaction plume, and that some of the entrained oxygen survives the fire to be pumped into the upper layer intact. This is confirmed by oxygen sensors in the upper layer and exit duct.

Figures A-7(a) and A-7(b) contrast an over-ventilated fire with an under-ventilated fire. (Mod 8; 400 $\mathrm{kW}$ at $500 \mathrm{~L} / \mathrm{s}$ and $\operatorname{Mod} 12 ; 800 \mathrm{~kW}$ at $100 \mathrm{l} / \mathrm{s}$ ). Mod 12 was terminated at approximately $300 \mathrm{~s}$ for safety 


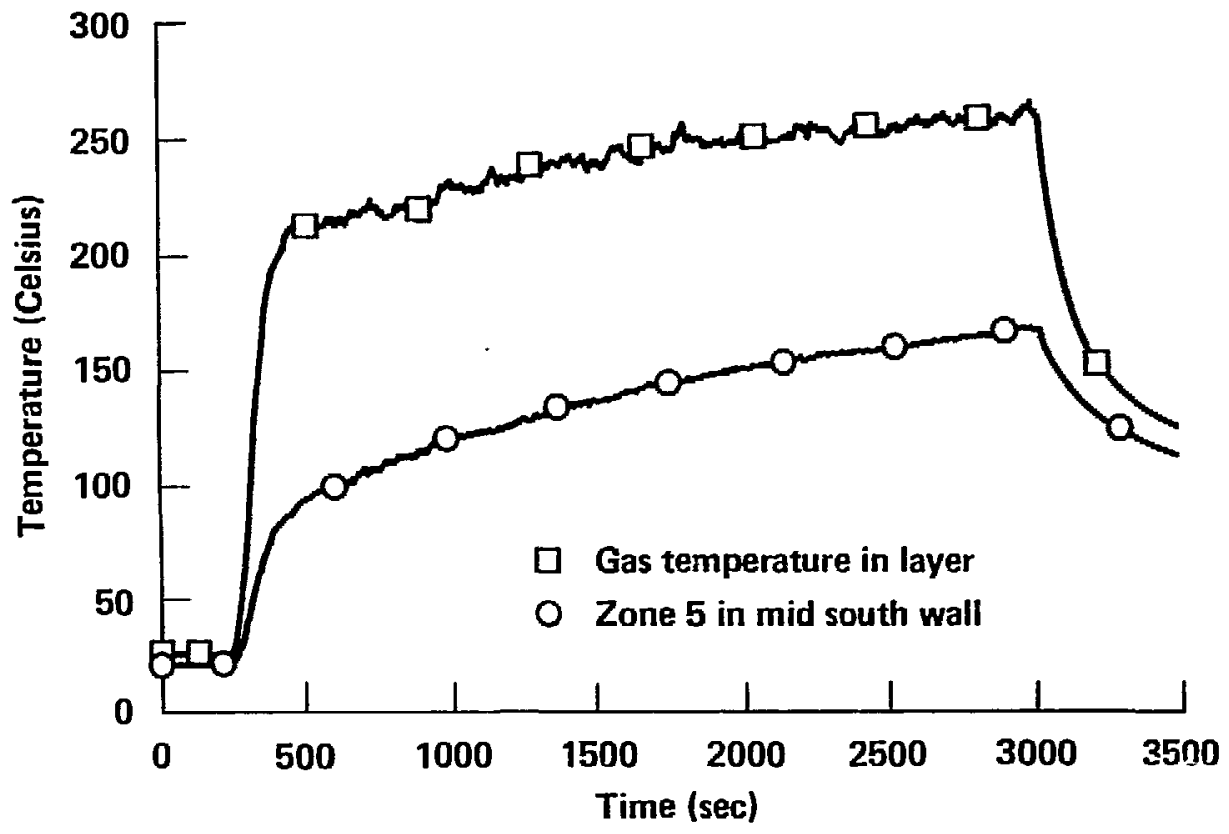

Figure A-5(a). Example temperature history for MCD 27B.

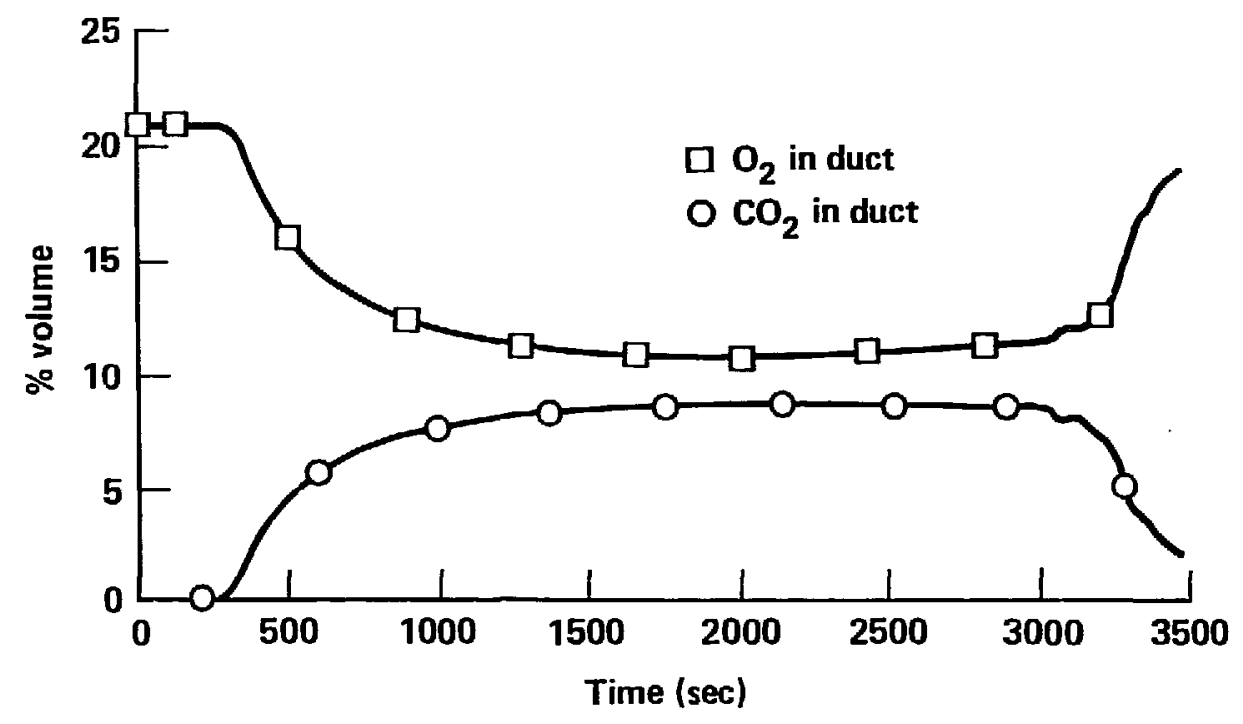

Figure A-5(b). Example major gas $\left(\mathrm{O}_{2}\right.$ and $\mathrm{CO}_{2}$ history) for $\mathrm{MOD} 27 \mathrm{~B}$. 


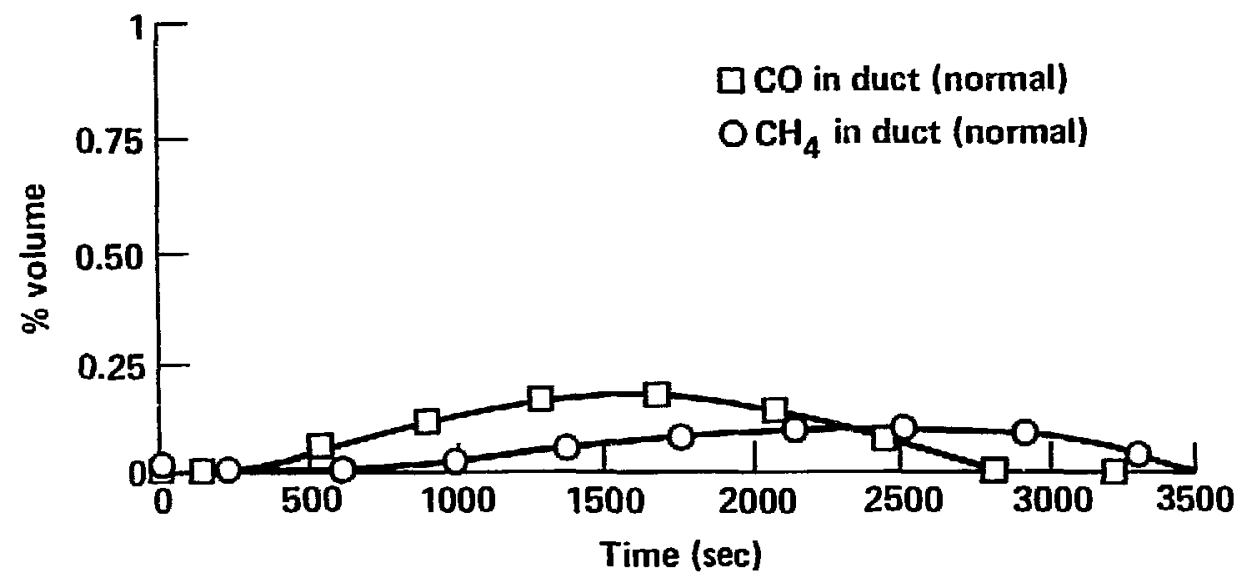

Figure A-5(c). Example minor gas (CO and $\mathrm{CH}_{4}$ history) for MOD $27 \mathrm{~B}$.

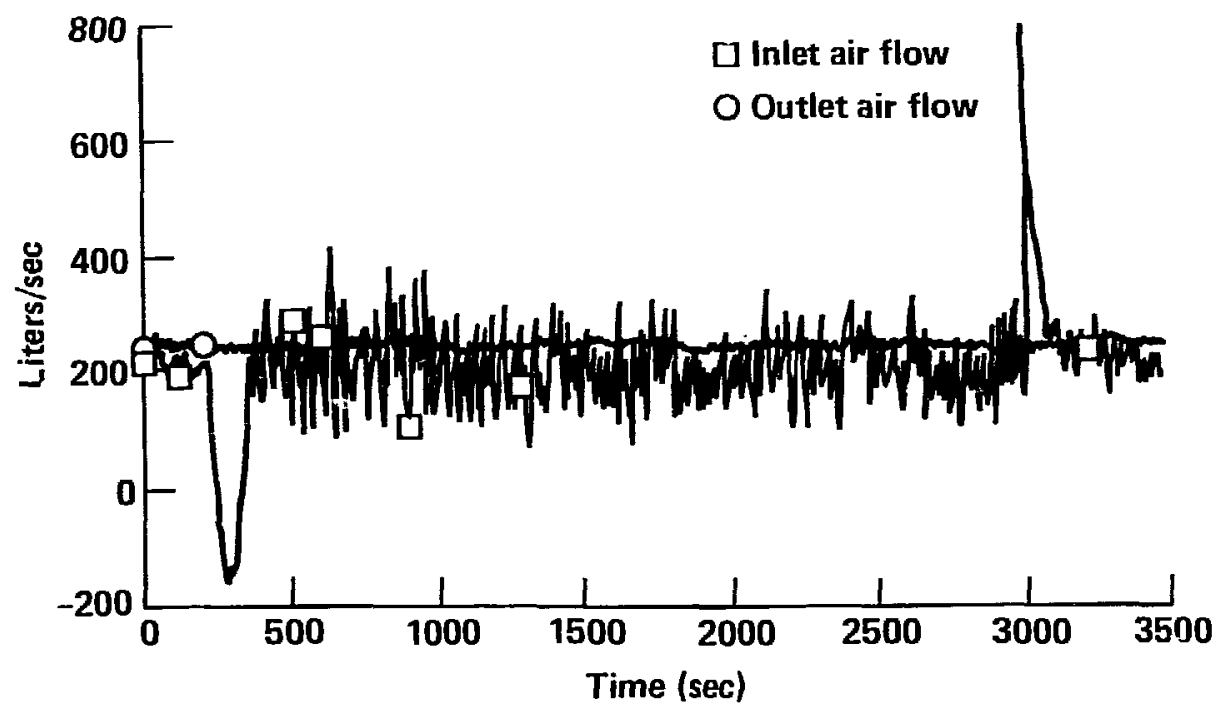

Figure A-5(d). Example airflow history for MOD 27B. 


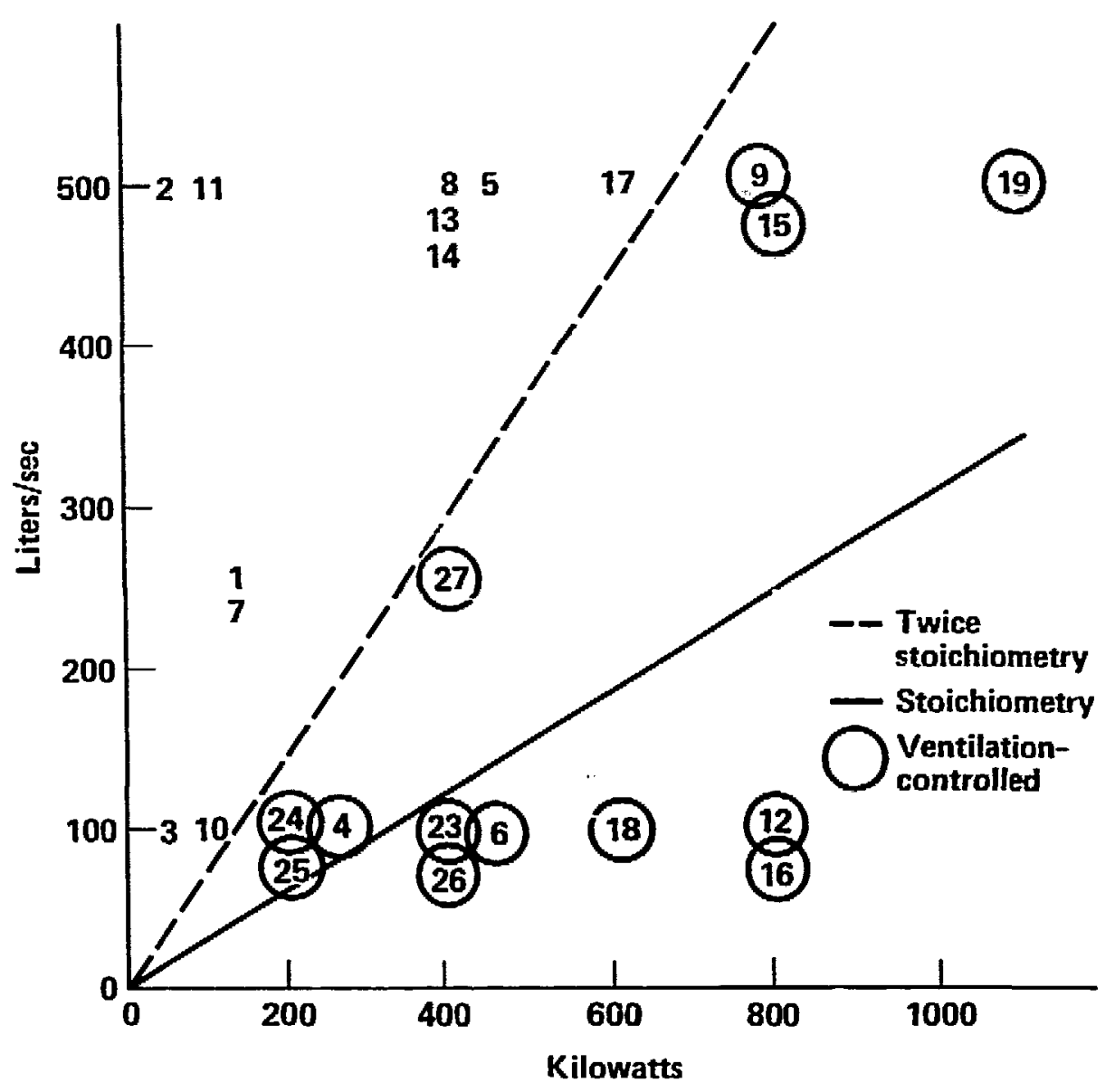

Figure A-6. Conditions of fire relative to stoichiometric fuel/air ratio.

reasons. All tests were terminated if total hydrocarbon level exceeded $10000 \mathrm{ppm}$, the lower ignition limit of methane, to avoid the potential danger of accidental deflagration. Note the rapid rise of $\mathrm{CO}$ and $\mathrm{CH}_{4}$ in Fig. A-7(b) for Mod 12. These signals illustrate extreme ventilation-limited conditions. In comparison, Mod 8 exhibits relatively well-behaved data; e.g., very low production of $\mathrm{CO}$ and $\mathrm{CH}_{4}$.

Figures A-8(a) and A-8(b) shows data from two fires with differcit fuels at the same initial ventilation rate and fire strength. MOD 26 is an isopropanol $\left(\mathrm{C}_{3} \mathrm{H}_{8} \mathrm{O}\right)$ spray fire and MOD 23 is an isostane $\left(\mathrm{C}_{8} \mathrm{H}_{18}\right)$ spray fire. These two very different fuels give remarkably similar results for most measurements. Table A3 contains tabular data for the other tests done during the 1982 series.

Figure A-9(a) shows temperature profiles of rake thermocouples at various times for Mod 27B. Two vertical columns (rakes) of thermocouples were positioned symmetrically east and west of the bum pan. Each rake contained 155 -mil chrome-alumel thermocouples at $30-\mathrm{cm}$ vertical intervals. The shape of the cell thermal profile or "upper layer" is quickly established (within $\mathbf{2 5 0} \mathrm{s}$ ) and remains essentially unchanged throughout the fire. For MOD $27 \mathrm{~B}$ this upper layer temperature is $200^{\circ} \mathrm{C}$, and rises to only $250^{\circ} \mathrm{C}$ at long times. One characteristic of these tests is that the tempcrature interface between the hot and cold layers is not well defined. It is more of a temperature gradient that asymptotically approaches infinity in the upper layer. In Fig. A-9(a), the history of the temperature profile to $1500 \mathrm{~s}$ shows this well. (Note that from here on all time references are from the start of the fire.) To make model evaluation easier, Steckler's two-layer equivalency technique (Alvares, ct al., 1982) was applied to these temperature profiles. This technique simplifies profile data into the two distinct layers used by most zone models. The results of this procedure are shown in Fig. A-9(b) for test MOD 27B at $1500 \mathrm{~s}$. Table A-4 suminarizes these calculated Steckler two-layer data for all tests in this.series. 


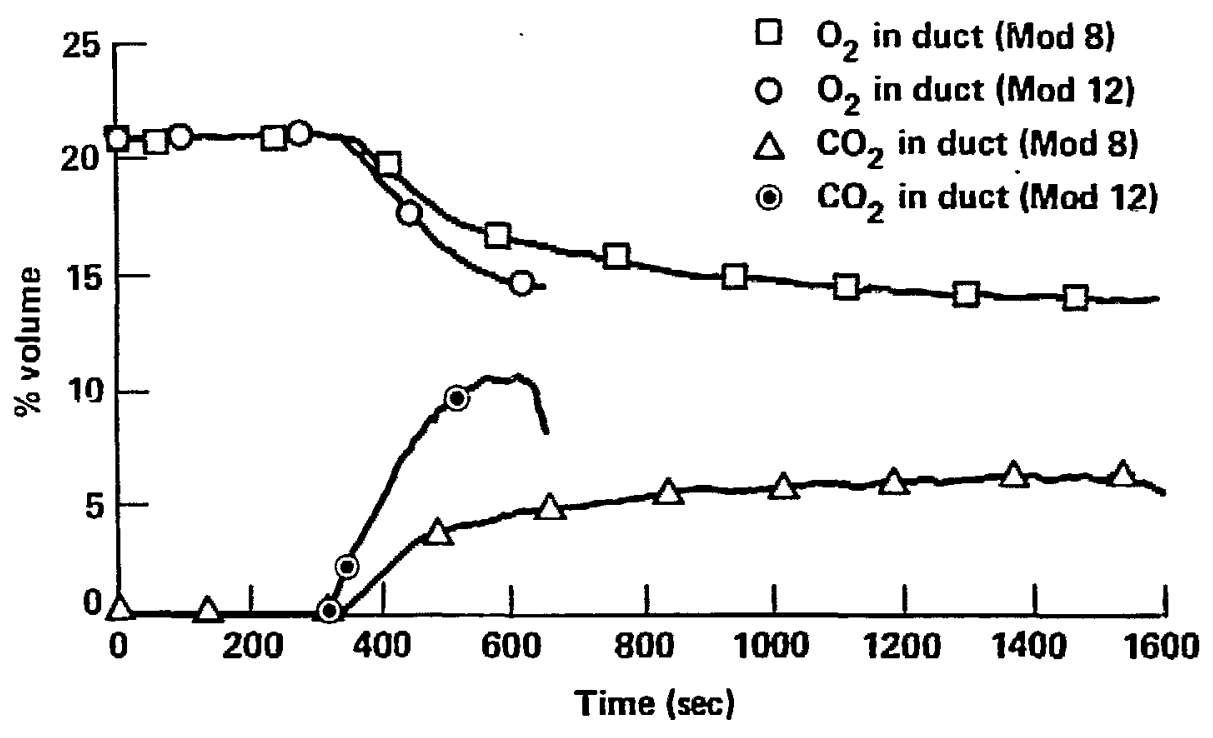

Figure A-7(a). Comparison of major gas $\left(\mathrm{O}_{2}\right.$ and $\left.\mathrm{CO}_{2}\right)$ histories for $\mathrm{MOD} 8$, an overventilated fire, and MUD 12, an underventilated fire.

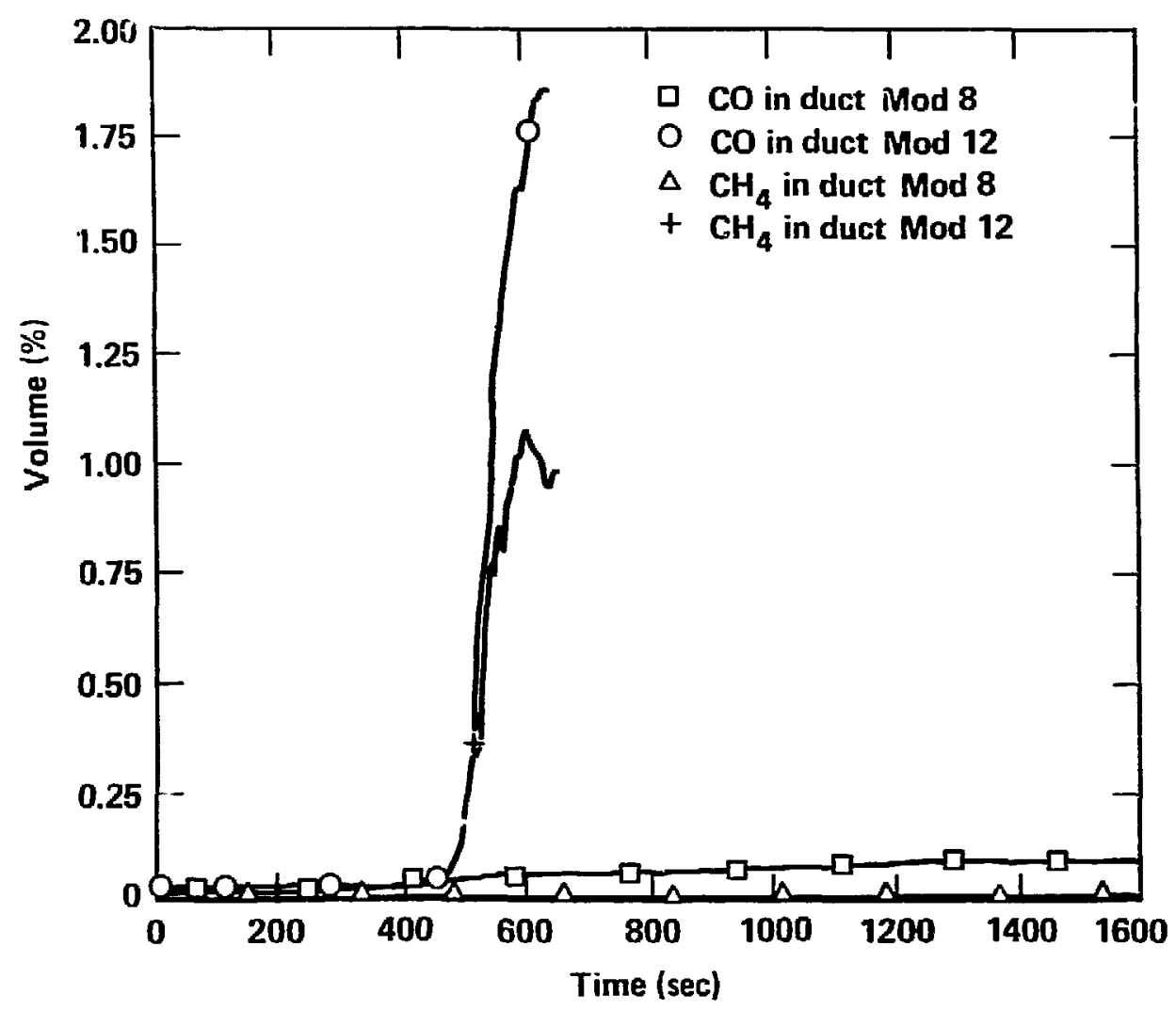

Figure A-7(b). Comparison of minor gas (CO and $\mathrm{CH}_{4}$ ) histories for MOD 8, an overventilated fire, and MOD 12, an underventilated fire. 


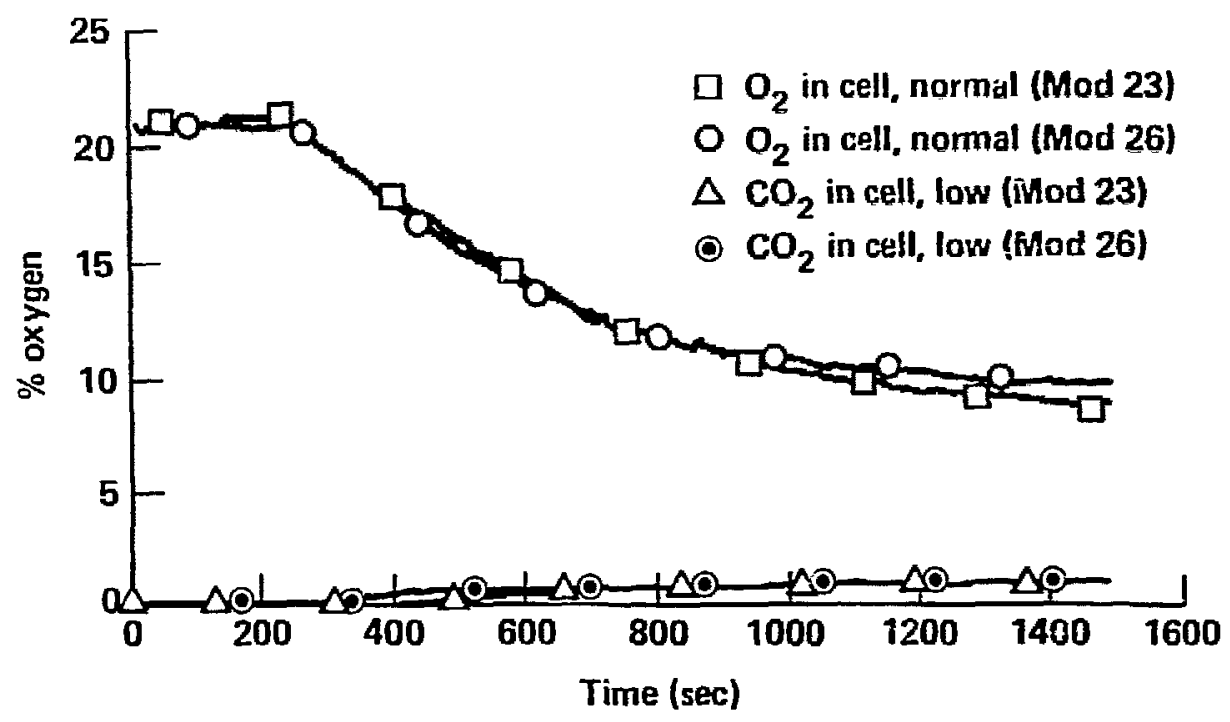

Figure A-8(a). Comparison of major gas $\left(\mathrm{O}_{2}\right.$ and $\left.\mathrm{CO}_{2}\right)$ histories for similar isopropanol and isooctane fires.

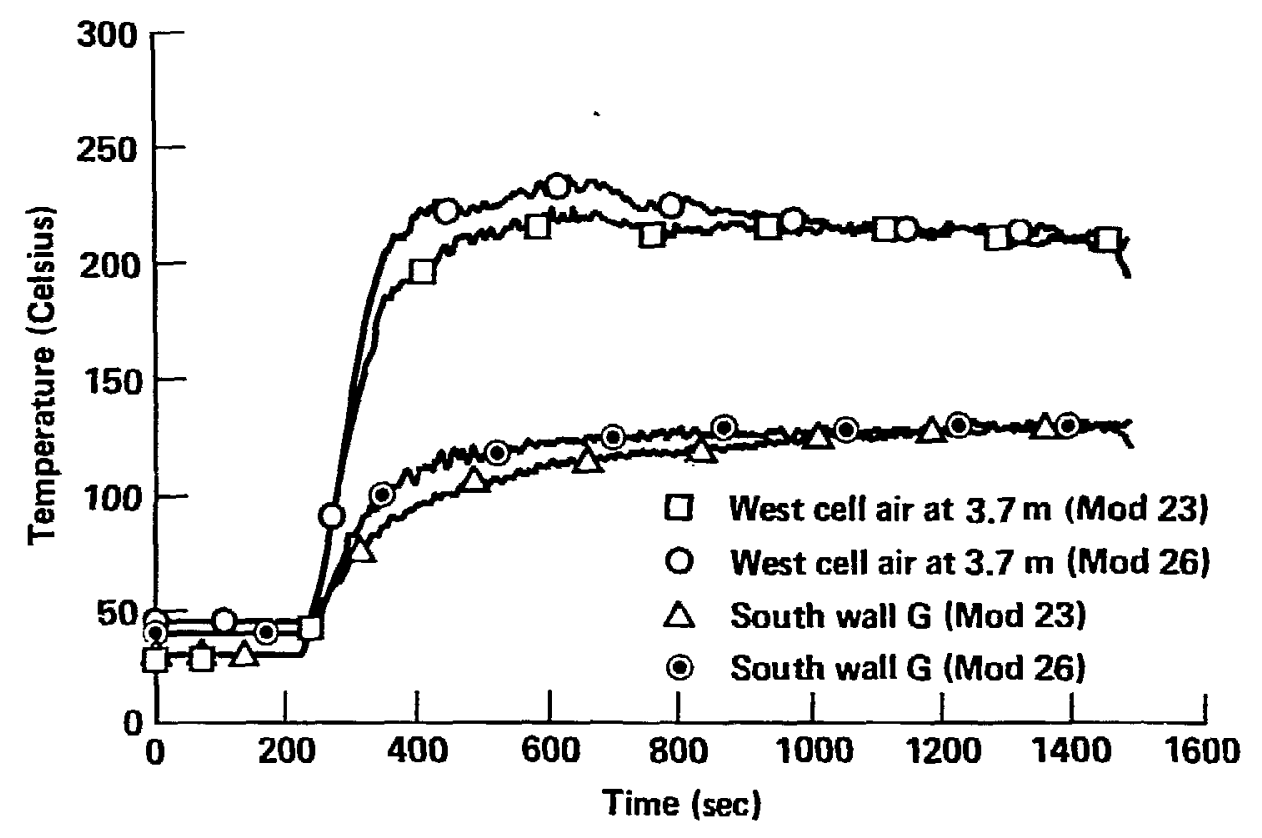

Figure A-8(b). Comparison of temperature histories for similar isopropanol and isocctane fires. 


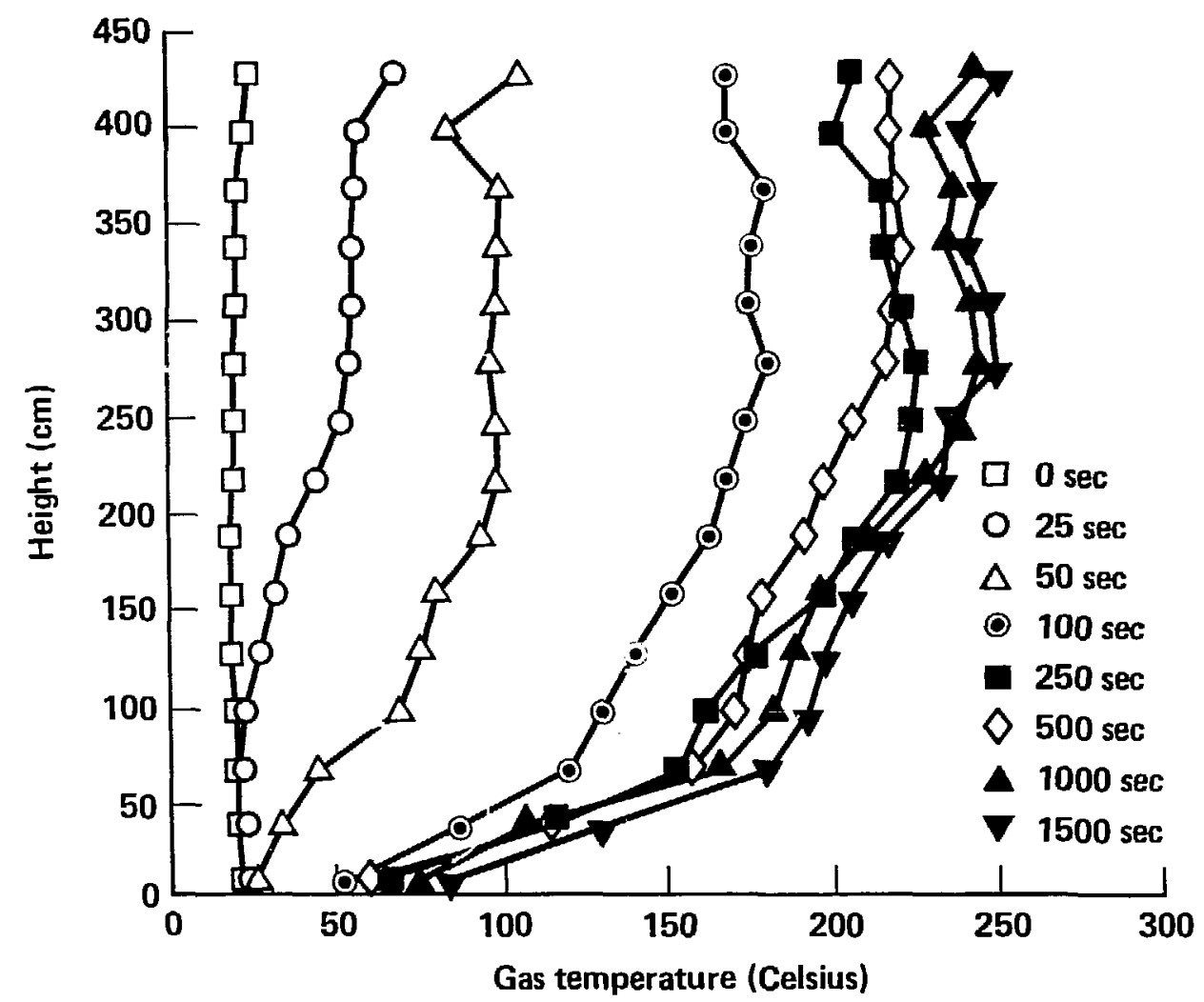

Figure A-9(a). Actual room gas temperature profiles for MOD 27B at early times.

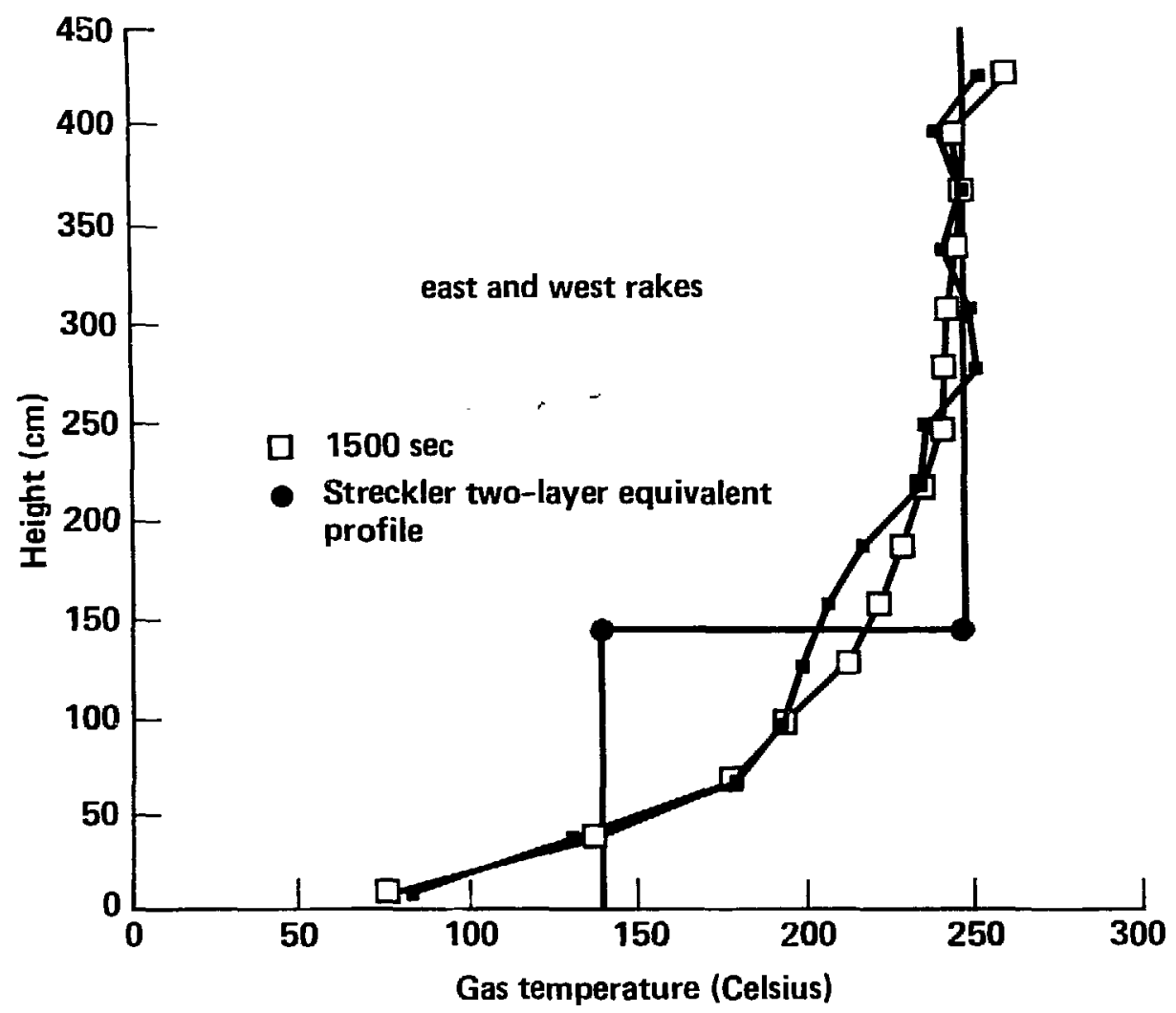

Figure A-9(b). Actual room gas temperature profile and Steckler two-layer equivalent profile for MOD 27B at 1500 s. 
Table A-4. Steckler two-layer temperatures.

\begin{tabular}{|c|c|c|c|c|}
\hline Test & $\begin{array}{l}\text { Time } \\
\text { (sec) }\end{array}$ & $\begin{array}{l}\text { Lower layer } \\
\text { temp }\left({ }^{\circ} \mathrm{C}\right)\end{array}$ & $\begin{array}{l}\text { Upper layer } \\
\text { temp }\left({ }^{\circ} \mathrm{C}\right)\end{array}$ & $\begin{array}{l}\text { Height of } \\
\text { layer interface } \\
\text { (m) }\end{array}$ \\
\hline MOD 1 & 900 & 59 & 134 & 1.58 \\
\hline MOD 2 & 1700 & 48 & 87 & 1.77 \\
\hline MOD 3 & 2200 & 59 & 107 & 1.53 \\
\hline MOD 4 & 1700 & 84 & 198 & 1.39 \\
\hline MOD 5 & 1700 & 111 & 294 & 1.51 \\
\hline MOD 6 & 400 & 105 & 253 & 1.54 \\
\hline MOD 6A & 500 & 99 & 232 & 1.52 \\
\hline MOD 7 & 1700 & 70 & 156 & 1.52 \\
\hline MOD 8 & 1200 & 116 & 237 & 1.41 \\
\hline MOD 9 & 600 & 142 & 297 & 1.17 \\
\hline MOD 9A & 800 & 147 & 292 & 1.22 \\
\hline MOD 10 & 1500 & 75 & 118 & 1.50 \\
\hline MOD 11 & 1200 & 54 & 91 & 1.65 \\
\hline MOD 11A & 1200 & 58 & 103 & 1.48 \\
\hline MOD 12 & 300 & 128 & 240 & 1.26 \\
\hline MOD 13 & 1200 & 129 & 245 & 1.49 \\
\hline MOD 14 & 1300 & 122 & 214 & 1.15 \\
\hline MOD 14A & 1200 & 119 & 213 & 1.22 \\
\hline MOD 15 & 800 & 155 & 272 & 1.15 \\
\hline MOD 16 & 300 & 135 & 215 & 1.15 \\
\hline MOD 17 & 1500 & 118 & 262 & 1.21 \\
\hline MOD 18 & 2300 & 107 & 202 & 1.35 \\
\hline MOD 19 & 1300 & 154 & 284 & 1.26 \\
\hline MOD 20 & 1700 & 63 & 98 & 1.45 \\
\hline MOD 23 & 1200 & 123 & 200 & 1.26 \\
\hline MOD 24 & 3300 & 114 & 189 & 1.25 \\
\hline MOD 25 & 2800 & 107 & 191 & 1.14 \\
\hline MOD 26 & 1300 & 113 & 202 & 1.08 \\
\hline MOD 27 & 1200 & 142 & 258 & 1.28 \\
\hline MOD 27 & 2200 & 148 & 258 & 1.20 \\
\hline MOD 27A & 1500 & 124 & 242 & 1.20 \\
\hline MOD 27A & 2300 & 119 & 229 & 1.15 \\
\hline MOD $27 B$ & 2700 & 133 & 256 & 1.10 \\
\hline
\end{tabular}

To validate the accuracy of the instrumentation, stringent-mass, energy, and species-balancing criteria were applied to all raw data (Alvares, et al., 1982). Mass flows in and out were corrected for temperature and density changes and checked to balance. Gas species are similarly checked to insure elemental balances. Measured fire strengths were compared against calculated fire strengths from $\mathrm{CO}_{2}$ and $\mathrm{CO}$ production and $\mathrm{O}_{2}$ consumption. This procedure provides a good measure of the data quality and identified when the quasi-steady-state was reached. The definition of quasi-steady-state is taken as the establishment of conditions where oxygen consumption and combustion gas formation becomes constant and species balancing occurs. For these tests, this occurs approximately $2000 \mathrm{~s}$ after the start of the fire and is highly dependent on the ventilation rate. The long time necessary to reach quasi-steady-state conditions is due to the large volume of the test cell. Balancing also indicated that approximately $80 \%$ of the energy from the fire was deposited in the thick Kastolite enclosure walls.

To validate these findings, the total heat flux to the walls was calculated using the wall surface temperature histories and Duhamel integral techniques (Arpaci, V. S., 1966, and Nikanja, M. and Greif, R., 1978). Wall temperatures were extrapolated and averaged (McGehee, D., 1983) to represent the eight zones shown in Fig. A-4.

Figure A-10 shows four typical wall temperature curves for Mod 27B. The four zones represented are: 1 - the ceiling above the fire; 4 - top near wall; 5 - middle near wall; and 6 - bottom near wall. All eight zones behave similarly at early times with a rapid temperature rise, $\left(-50^{\circ} \mathrm{C}\right.$ in $\left.4 \mathrm{~min}\right)$, before beginning their long approach to a quasi-steady distribution. The middle wall zone, 5 , initially leads the top wall zone, 4, due to its greater view factor for direct radiation from the flame. However, after $\sim 10$ min, zone 4 


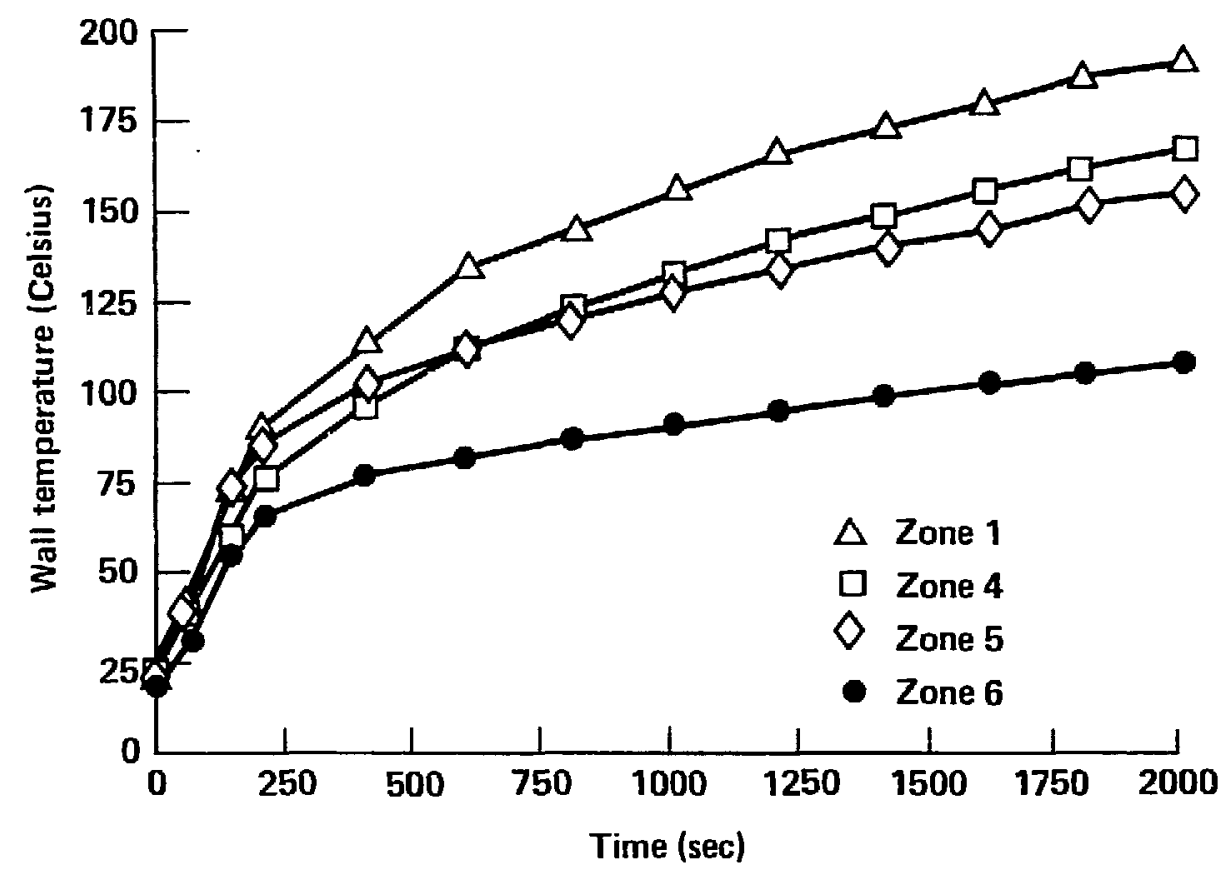

Figure A-10. Zonal wall temperatures for MOD 27B.

catches up with zone 5 because of increased radiation from the ceiling and hot upper layer. At long times, the upper zone, 4 , temperatures exceed the middle zone, 5 , by $\sim 10^{\circ} \mathrm{C}$.

The fast, early rise is attributed to the cold walls experiencing direct flame radiation, much like coming inside during winter to stand in front of a fireplace. Numerical curve fitting was done mimicking the two time regime behaviors shown in Fig. A-10, with a linear rise followed by a slow "baking" as the half power of time.

The data from each thermocouple in each zone was fit with

$\theta_{\mathrm{w}}=\mathrm{bt}$,

for $t<t_{\text {tr }}$

and

$\theta_{\mathrm{w}}=\mathrm{c}+\mathrm{ft}^{\mathrm{1} / 2}$,

for $t \geq t_{t r}$

where $\theta_{w}=T_{w}-T_{w i}$, is the surface temperature increase above its initial value. $t_{t r}$ is -3 min. This time dependence, along with approximate wall thermal properties, in the standard Duhamel integral

$q^{\prime \prime}(t)=\left(\frac{\kappa \rho c}{\pi}\right)^{1 / 2}\left[\frac{\theta_{w}(t)}{t^{1 / 2}}+\int_{0}^{t \theta_{w}(t)-\theta_{w}(s)} \frac{2(t-s)^{3 / 2}}{d s}\right]$

gives a local heat flux

$q^{\prime \prime}(t)=\left(4 b^{2} t \kappa \rho c / \pi\right)^{1 / 2}$,

for $t<t_{t r}$

and

$q^{\prime \prime}(t)=\left(\frac{\kappa \rho c}{\pi}\right)^{1 / 2}\left[\frac{c}{t^{1 / 2}}+b t_{t r}^{1 / 2}+f\left[2.57-\sin ^{-1} \frac{t_{t r}^{1 / 2}}{t}-\frac{\left(t^{1 / 2}-t_{t r}^{1 / 2}\right)}{\left(t-t_{t r}\right)^{1 / 2}}\right]\right]$ for $t>t_{t r}$

where $t_{t r}=\left(f+\left(f^{2}+4 b c\right)^{1 / 2} /(2 b)\right)^{2}$. 
To compensate for the error of concentrating the thermocouple array on that portion of the wall closest to the fire, a steric factor of 0.5 for the walls was introduced. This lowered the flux calculated from Eq. (3) to the level shown in Fig. A-11. The floor zones were deleted as negligible. Each thermocuople's flux was calculated and the flux average applied to the zone surface area to determine the total power into each zone as a function of time. Summing over all zones then gave the total power history to the test cell surface (McGehee, D., 1983).

Figure A-12 shows a comparison of this calculation with the estimate of $Q$ determined from data obtained using the species, temperature and flow measurements in the exit duct for test $27 \mathrm{~B}, 400 \mathrm{~kW}$ at 250 $1 / \mathrm{s}$. The total heat flux to the walls exhibits a peak that occurs at roughly the same time as the peak in the air inflow. Initially, both the convective and radiative heat transfer is large because of the large temperature difference between gas and surfaces and the direct view from the fire. The gas and wall temperatures rise in parallel and are somewhat interdependent. When the rate of gas temperature rise is reduced $(\sim 250 \mathrm{~s})$, the rate of change in the wall temperature is slowed down, indicating a significantly reduced rate of heat transfer. As noted earlier, the $m$ ignitude of the air flow peak is directly dependent on fire strength. The same relationship holds for the heat rate peak corresponding to the heat transfer transition time, thus illustrating that the enclosure volume is so large that no ventilation control can occur during the first minutes of burning.

In addition, Fig. A-12 shows the results of calculating the convective fraction of the total heat flux using published correlations (Cooper, 1982 and Zukoski, et al., 1975). The radiative fraction was then calculated as the difference between the total and the convective flux. In all cases, net radiation is from 2 to 4 times greater than convection. Spot checks with radiometer measurements indicate these radiation estimates are of the correct magnitude.

Table A-5 gives the flux distribution among zones and the partition of the absorbed energy into net radiation and convection at the long times indicated for several different tests. The fire strengths and mass flow rates for these tests are given in Table A-2. The last two columns give the caıculated and measured fluxes averaged over the wall and ceiling surface areas. This agreement is good, considering the geometric averaging required and the uncertainties in measuring the surface temperatures. It is also difficult to get accurate average wall properties (Somerton, 1958). In the future, more complete radiation calculations are planned, both because of their own importance and their value in making a critical, full-scale evaluation

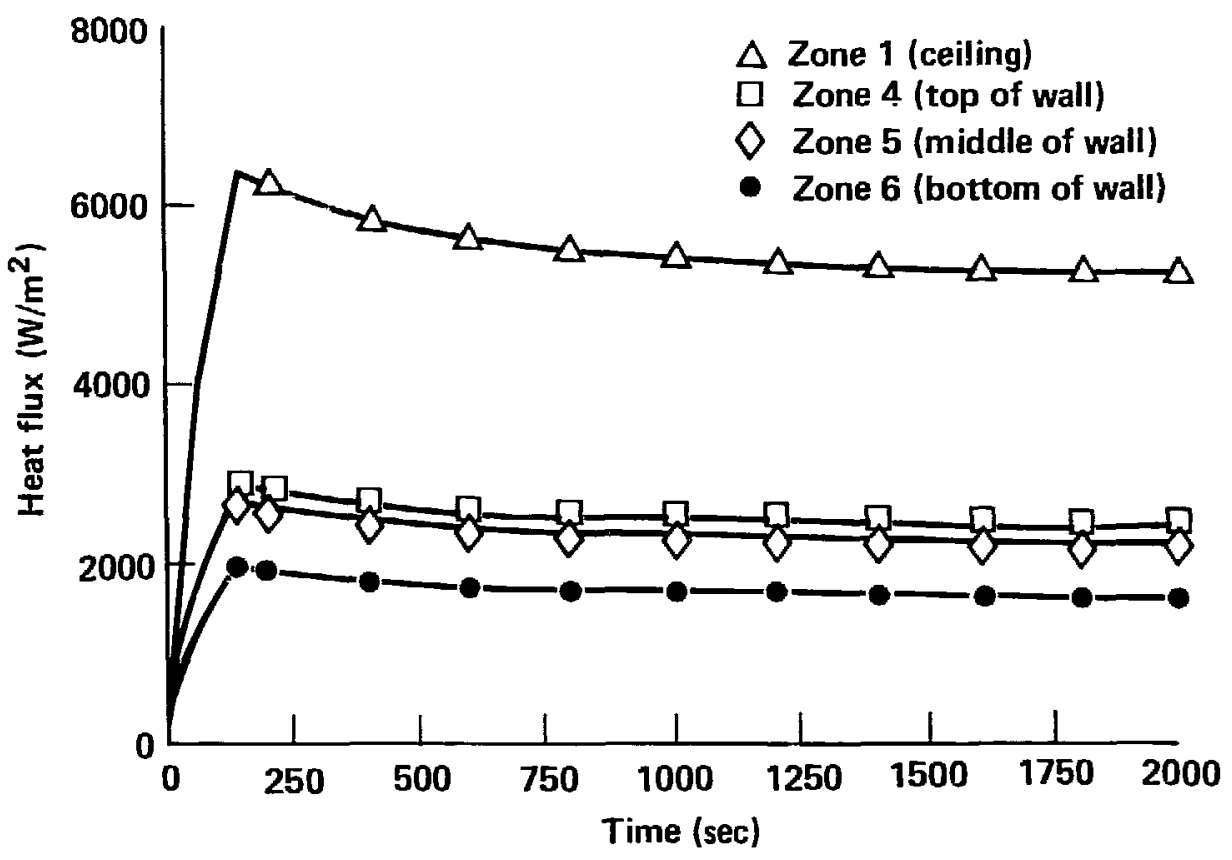

Figure A-11. Projected heat flux to wall zones for MOD $27 \mathrm{~B}$. 


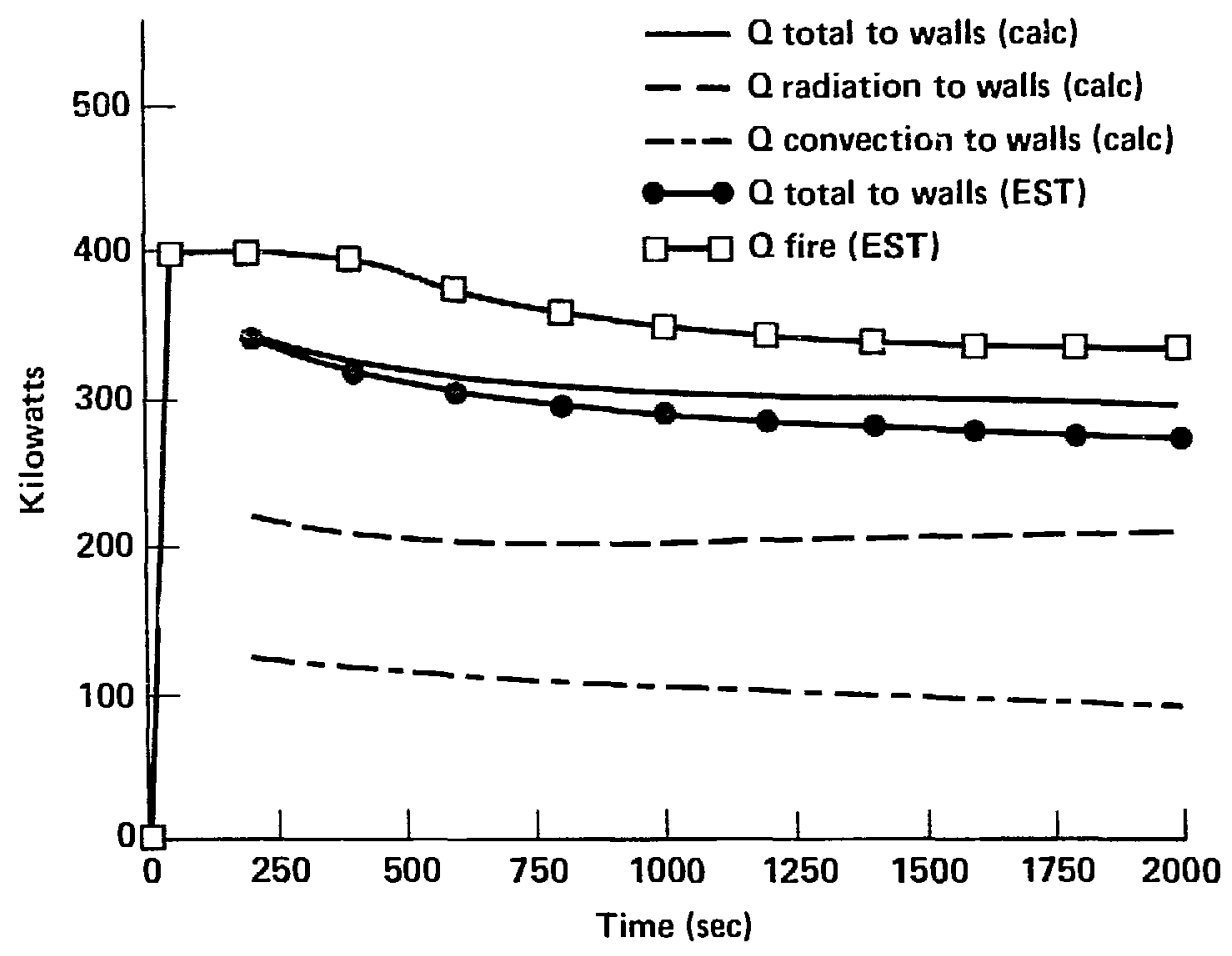

Figure A-12. Results of Duhamel analysis for MOD 27B.

of the convective correlations. Further tests are planned with a more representative thermocouple array embedded very slightly beneath the enclosure surface.

The literature suggests these tests are unique. The low inlet-high outlet ventilation pattem does not allow intermixing of the hot and cold layers. The thick Kastolite walls absorb $80 \%$ of the energy of the fire, keeping gas temperatures below $350^{\circ} \mathrm{C}$. Half an hour is required to reach quasi-steady-state because of the large room volume. Having established these data as reliable and representative for these specific conditions, they are is used to compare several fire model predictions.

\section{Enclosure-Fire-Model Validation}

The model selection procedure used was unsophisticated. Data were sent to any organization or institution that expressed an interest in attempting to predict fire characteristics from the initial conditions of our tests. Three tests were selected for model validation analysis: MOD 8, MOD 9, and MOD 27B. These tests represent ventilated $(400 \mathrm{~kW}$ at $500 \mathrm{~L} / \mathrm{s})$, and under-ventilated $(800 \mathrm{~kW}$ at $500 \mathrm{~L} / \mathrm{s})$, and $(400 \mathrm{~kW}$ at $250 \mathrm{~L} / \mathrm{s}$ ) fires. The six models compared in this report consist of those respondents who had the ability to modify their model to account for the unusual condition of forced ventilation. Five of the six codes were two-layer zone models from Harvard (Mitler and Emmons, 1981, and Mitler, 1982), LANL. (Krause, 1982), LLNL (Creighton, 1982), Cal Tech Il (Zukoski, 1980), and PNL (Orzawski, ct al., 1982). One code has a single layer zone code, Cal Tech I (Zukoski, 1982).

Eight fire parameters were selected for comparison of the models. They are listed here in order of their importance, both as model indicators and as paramete1s for risk analysis.

1. Upper layer gas tempreature $\left({ }^{\circ} \mathrm{C}\right)$.

2. Fire strength $(\mathrm{kW})$.

3. Total heat loss to walls $(\mathrm{kW})$.

4. Oxygen conce ntration (\% vol).

5. Lower layer height $(\mathrm{m})$.

6. Inlet ventilation $(\mathrm{g} / \mathrm{sec})$.

7. Wall temperature $\left({ }^{\circ} \mathrm{C}\right)$.

8. Lower layer gas temperature $\left({ }^{\circ} \mathrm{C}\right)$. 
Table A-5. Calculated heat fluxes.

\begin{tabular}{|c|c|c|c|c|c|c|c|c|c|c|c|c|c|}
\hline $\begin{array}{l}\text { Zone Number } \\
\text { Area }\left(\mathrm{m}^{2}\right)\end{array}$ & $\begin{array}{c}1 \\
8 \\
\left(\mathrm{~kW} / \mathrm{m}^{2}\right)\end{array}$ & $\begin{array}{c}2 \\
8 \\
\left(\mathrm{~kW} / \mathrm{m}^{2}\right)\end{array}$ & $\begin{array}{c}3 \\
8 \\
\left(k W / m^{2}\right)\end{array}$ & $\begin{array}{c}4 \\
18 \\
\left(\mathrm{~kW} / \mathrm{m}^{2}\right)\end{array}$ & $\begin{array}{c}5 \\
18 \\
\left(\mathrm{~kW} / \mathrm{m}^{2}\right)\end{array}$ & $\begin{array}{c}6 \\
18 \\
\left(\mathrm{~kW} / \mathrm{m}^{2}\right)\end{array}$ & $\begin{array}{c}7 \\
18 \\
\left(\mathrm{~kW} / \mathrm{m}^{2}\right)\end{array}$ & $\begin{array}{c}8 \\
18 \\
\left(k W / m^{2}\right)\end{array}$ & $\begin{array}{c}\text { Ceiling } \\
\text { Fluence } \\
24 \\
(\mathbf{k W})\end{array}$ & $\begin{array}{c}\text { Wall } \\
\text { Fluence } \\
90 \\
(\mathrm{~kW})\end{array}$ & $\begin{array}{c}\text { Cell } \\
\text { Fluence } \\
114 \\
\text { (kW) }\end{array}$ & $\begin{array}{l}\text { Calc. } \\
\text { Avg. } \\
\text { Flux }\end{array}$ & $\begin{array}{l}\text { Meas. } \\
\text { Avg. } \\
\text { Flux }\end{array}$ \\
\hline \multicolumn{14}{|c|}{ Mad 7 at $1700 \mathrm{sec}$} \\
\hline Convective & 0.7 & 0.6 & 0.4 & 0.4 & 0.3 & 0.3 & 0.3 & 0.2 & 13.6 & 27.0 & 40.6 & 0.4 & \\
\hline Radiative & 2.3 & 1.4 & 2.3 & 0.6 & 0.6 & 0.2 & 0.5 & 0.2 & 48.0 & 37.8 & 85.8 & 0.7 & \\
\hline Total & 3.0 & 2.0 & 2.7 & 1.0 & 0.9 & 0.5 & 0.8 & 0.4 & 61.6 & 64.8 & 126.4 & 1.3 & 1.1 \\
\hline \multicolumn{14}{|c|}{ Mod 8 at $1100 \mathrm{sec}$} \\
\hline Convective & 1.8 & 1.2 & 0.9 & 0.9 & 0.6 & 0.6 & 0.7 & 0.5 & 31.2 & 59.4 & 90.6 & 0.8 & \\
\hline Radiative & 4.8 & 5.5 & 5.2 & 1.4 & 1.8 & 1.1 & 1.3 & 1.3 & 124.0 & 124.2 & 248.2 & 2.2 & \\
\hline Total & 6.6 & 6.7 & 6.1 & 2.3 & 2.4 & 1.7 & 2.0 & 1.8 & 155.2 & 183.6 & 338.8 & 3.0 & 3.1 \\
\hline \multicolumn{14}{|l|}{ Mod 9 at $550 \mathrm{sec}$} \\
\hline Convective & 3.1 & 1.9 & 1.4 & 1.3 & 0.9 & 0.8 & 0.9 & 0.6 & 51.2 & 81.0 & 132.2 & 1.1 & \\
\hline Radialive & 9.0 & 11.6 & 11.0 & 3.8 & 3.5 & 2.3 & 3.1 & 2.8 & 252.8 & 279.0 & 531.8 & 2.2 & \\
\hline Total & 12.1 & 13.5 & 12.4 & 5.1 & 4.4 & 3.1 & 4.0 & 3.4 & 304.0 & 360.0 & 664.0 & 5.8 & 5.5 \\
\hline \multicolumn{14}{|c|}{ Mod 17 al $2000 \mathrm{sec}$} \\
\hline Conveclive & 1.6 & 1.4 & 1.1 & 0.8 & 0.6 & 0.7 & 0.5 & 0.5 & 32.8 & $\mathbf{5 5 . 8}$ & 88.6 & 0.8 & \\
\hline Radiative & 6.8 & 6.0 & 5.1 & 2.2 & 2.2 & 1.1 & 2.3 & 1.2 & 143.2 & 162.0 & 305.2 & 2.7 & \\
\hline Total & 8.4 & 7.4 & 6.2 & 3.0 & 2.8 & 1.8 & 2.8 & 1.7 & 176.0 & 217.8 & 393.8 & 3.5 & 4.7 \\
\hline \multicolumn{14}{|c|}{ Mod 27B at $2000 \mathrm{sec}$} \\
\hline Convective & 1.9 & 1,4 & 1.0 & 0.8 & 0.6 & 0.6 & 0.6 & 0.4 & 34.4 & 54.0 & $\mathbf{8 8 . 4}$ & 0.8 & \\
\hline Radiative & 3.3 & 3.4 & 3.2 & 1.6 & 1.6 & 1.0 & 1.4 & 1.3 & 79.2 & 124.2 & 203.4 & 1.8 & \\
\hline Total & 5.2 & 4.8 & 4.2 & 2.4 & 2.2 & 1.6 & 2.0 & 1.7 & 113.6 & 178.2 & 291.8 & 2.6 & 2.6 \\
\hline
\end{tabular}


Table A-6 contains quasi-steady-state test data and long-time model predictions for the three com parison tests. These tables present an uverview of a model's abilities and performance celative to the other models, but they can be deceiving. A time history is a better indication of a model's accuracy. An example' of this is illustrated in Table A-b(b). The upper layer temperature predictions of Cal Tech I and II, LANI. and LLNL appear to agree well with the data. However, in Fig. A-13 (a)-(b), it is clear that the Ca! Tech i program is simply intersecting the other predictions and the real data on the way to higher temperatures. The Cal Tech I program does not appear to approach quasi-steady state. LANL, PNL and Harvard have substantially better upper layer temperature "temporal shapes" but predict temperatures too high or too low. For all tests, Harvard's "temporal shape" agrees well with the data; however, it is significantly lower $\left(80-120^{\circ} \mathrm{C}\right)$ than the data. It needs some improvement to allow more energy into the hot layer.

Looking at Table A-6, the Harvard code appears to have the best prediction of the fire strength in the ventilation limited condition. The Cal Tech I code requires that the oxygen concentration goes to zoro before oxvgen starvation occurs, limiting the fire strength. The oxygen concentration never approaches zero in these tests since ventilation control limits the burning rate. A realistic empirical $\mathrm{O}$, limit could be incorporated into this code to inıprove it. The LLNL, LANL and Cal Tech Il codes do not account for the possibility of oxygen starvation.

When comparing the prediction for heat loss to the walls it was clear that models which incorrectly predicted the fire strength would have problems. Therefore, they are compared using the ratio of the heat lost to the walls to the predicted fire strength. The Cal Tech 1 code was clearly better than the others in this regard $(80-86 \%)$. The Harvard code $(50 \%)$ was again troubled by its lack of energy in the hot layer, as was PNL (30-60\%). The other three models require this ratio as an input parameter. The Borhamwood Fire Researcli Station finite difference program (Cox, 1983) was run for MOD 8 and predicted the heat loss quite well. The datra showed a $75 \%$ heat loss to the walls, and rox predicted $76-77 \%$.

Figure A-14 (a)-(b) compares the actual oxygen depletion curves for MOD 9 and MOD 27B with the four models that attempt to predict it. None of the programs predict oxygen depletion very well in these underventilated tests. The Cal Tech I model does, however, predict a consistently low depletion value (i.e., more $\mathrm{O}_{2}$ consumption). This is a more useful program from a risk-analysis viewpoint in that it doesn't underestimate the hazard. The PNL prediction for MOD 9 diverges from the data and other predictions at $11 \% \mathrm{O}_{2}$, illustrating this model's threshold of ventilation control.

No model was completely successful in predicting all eight parameters evaluated. In fact, no model was consistently close $( \pm 5 \%)$ on any parameter except fire strength. Most models were inconsistent, giving good predictions on one parameter and missing altogether on others. The overall performance evaluation process was very difficult. Nevertheless, it is possible to tentatively orde- the models relative to their usefulness in predicting the results of forced ventilation enclosure fires. In this order, the Cal Tech I and the PNL codes were the most successful. The Harvard and LANL codes were found to be moderately useful, whereas the modest abilities and questionable results of the LLNL and Cal Tech 11 codes make their usefulness limited.

\section{Conclusions}

These $t$ :sts provide new insights on the complexities of a fire in forced ventilation enclosures and should prove useful in future fire risk analyses of fires in these enclosures. They provide a firm foundation for further tests. Additional tests have been completed, in which the position of the fire was moved within the room and the location of ventilation ducts and wall thermocouples was changed. Preliminary results indicate that sharper thermal layering occurs when the fire is elevated. Subsequent tests will better define the interaction of ventilation and fire locations.

Data comparisons also point out the deficiencies of the current fire models to predict the important parameters of a fire in a forced ventilation enclosure. Some of the difficulties are minor problems with simple solutions; others are more complex. As more data become available, these problems may be solved. None of the current programs, however, are ready for unqualified use in fire hazard risk analyses. 
Table A-6. Comparison of model predictions with tests data MOD 8.

\begin{tabular}{|c|c|c|c|c|c|c|c|}
\hline Units & Data & Harvard & Cal Tech I & PNL & LANL & Cal Tech II & LLNL \\
\hline Time (sec) & 1200 & 1200 & 1200 & 1000 & 500 & 800 & 300 \\
\hline Upper Layer Temp $\left({ }^{\circ} \mathrm{C}\right)$ & 232 & 152 & 228 & 272 & 163 & 160 & 191 \\
\hline Fire strength $(\mathrm{kW})$ & 400 & 395 & 399 & 400 & 391 & 400 & 400 \\
\hline Heat loss to walls (kW) & 300 & 182 & 317 & 126 & 313 & 320 & 320 \\
\hline Oxygen concentration ( $\%$ vol) & 14.0 & 12.1 & 13.3 & 16.3 & 14.7 & - & - \\
\hline Lower layer height (m) & 1.30 & 0.36 & - & 0.80 & 2.84 & 0.30 & 0.99 \\
\hline Wall temperature $\left({ }^{\circ} \mathrm{C}\right)$ & $135-180$ & 113 & 151 & - & - & - & - \\
\hline Lower layer temp $\left({ }^{\circ} \mathrm{C}\right)$ & 112 & 21 & 228 & 272 & 80 & 21 & 21 \\
\hline Inlet spike min (sec) & (40) & (2) & (50) & (20) & (11) & (30) & - \\
\hline Inlet spike (g/sec) & 25.0 & 90 & 100 & -80 & 75 & 344 & - \\
\hline
\end{tabular}

MOD 9

\begin{tabular}{|c|c|c|c|c|c|c|c|}
\hline Units & Data & Harvard & Cal Tech I & PNL & LANL & Cal Tech II & LLNL \\
\hline Time (sec) & 600 & 600 & 600 & 600 & 630 & 800 & 300 \\
\hline Upper Layer Temp $\left({ }^{\circ} \mathrm{C}\right)$ & 299 & 175 & 351 & 267 & 329 & 304 & 388 \\
\hline Fire strength $(\mathrm{kW})$ & 700 & 482 & 801 & 556 & 786 & 800 & 800 \\
\hline Heat loss to walls (kW) & 600 & 231 & 682 & 327 & 629 & 640 & 640 \\
\hline Oxygen concentration ( $\%$ vol) & 6.5 & 7.6 & 4.0 & 10.8 & 7.9 & - & - \\
\hline Lower layer height (m) & 1.29 & 0.33 & - & 0.75 & 2.25 & 0.25 & 0.87 \\
\hline Wall temperature $\left({ }^{\circ} \mathrm{C}\right)$ & $170-270$ & 126 & 215 & - & - & - & - \\
\hline Lower layer temp $\left({ }^{\circ} \mathrm{C}\right)$ & 146 & 34 & 351 & 34 & 136 & 34 & 34 \\
\hline Inlet spike min (sec) & (15) & (2) & (20) & $(20)$ & (11) & $(30)$ & - \\
\hline Inlet spike (g/sec) & -420 & -554 & -570 & -180 & -400 & 117 & - \\
\hline
\end{tabular}

MOD 27B

\begin{tabular}{|c|c|c|c|c|c|c|c|}
\hline Units & Data & Harvard & Cal Tech I & PNL & LANL & Cal Tech II & LLNL \\
\hline rime (sec) & 2200 & 2200 & 2200 & 2200 & 1800 & 800 & 300 \\
\hline Upper Layer Temp $\left({ }^{\circ} \mathrm{C}\right)$ & 252 & 158 & 287 & 222 & 282 & 287 & 287 \\
\hline Fire strength $(\mathbf{k W})$ & 330 & 341 & 399 & 295 & 391 & 400 & 400 \\
\hline Heat loss to walls ( $\mathrm{kW}$ ) & 270 & 165 & 329 & 154 & 313 & 320 & 320 \\
\hline Oxygen concentration ( $\%$ vol) & 11.0 & 6.8 & 9.4 & 11.3 & 9.6 & - & - \\
\hline lower layer height $(\mathrm{m})$ & 1.22 & 0.28 & - & 0.64 & 0.73 & 0.15 & 0.75 \\
\hline Wall temperature $\left(^{\circ} \mathrm{C}\right)$ & $180-210$ & 123 & 206 & - & - & - & - \\
\hline Lower layer temp $\left({ }^{\circ} \mathrm{C}\right)$ & 136 & 18 & 287 & 87 & 111 & 18 & 18 \\
\hline Inlel spike min (sec) & (15) & (2) & $(20)$ & (20) & $(20)$ & (30) & - \\
\hline Inlut spike $(g / \mathrm{sec})$ & -200 & -210 & -300 & -410 & -210 & 34 & - \\
\hline
\end{tabular}




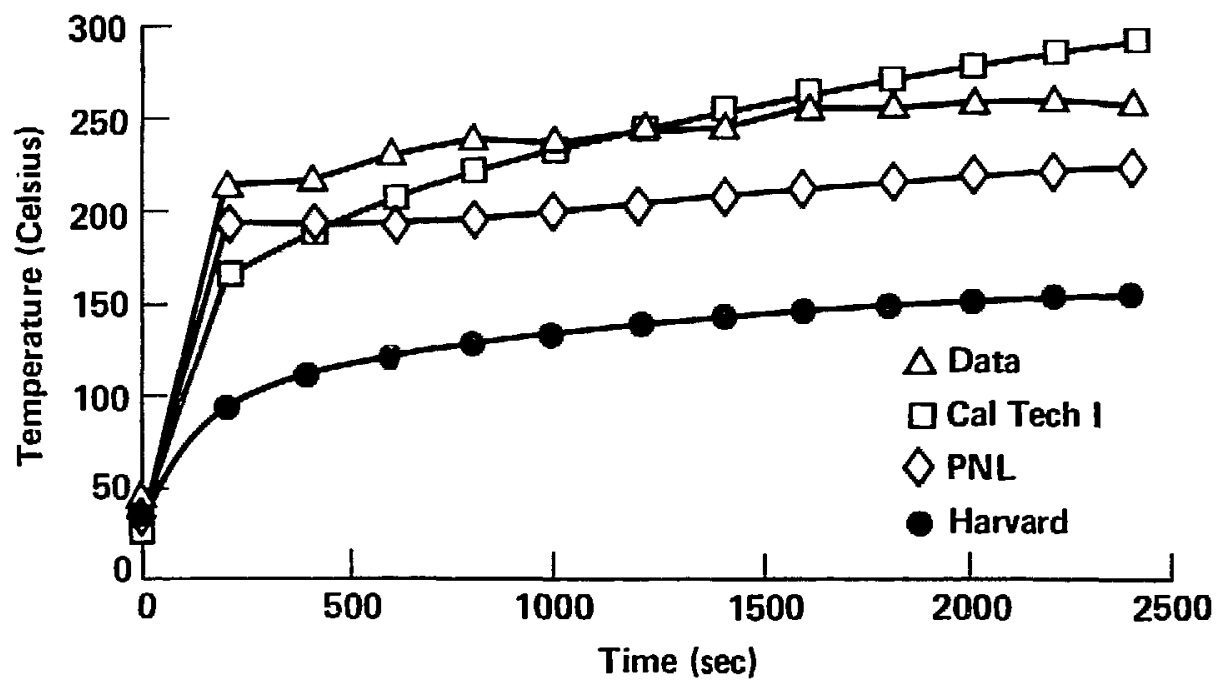

Figure A-13(a). Comparison of several models' gas temperature predictions for MOD 27B.

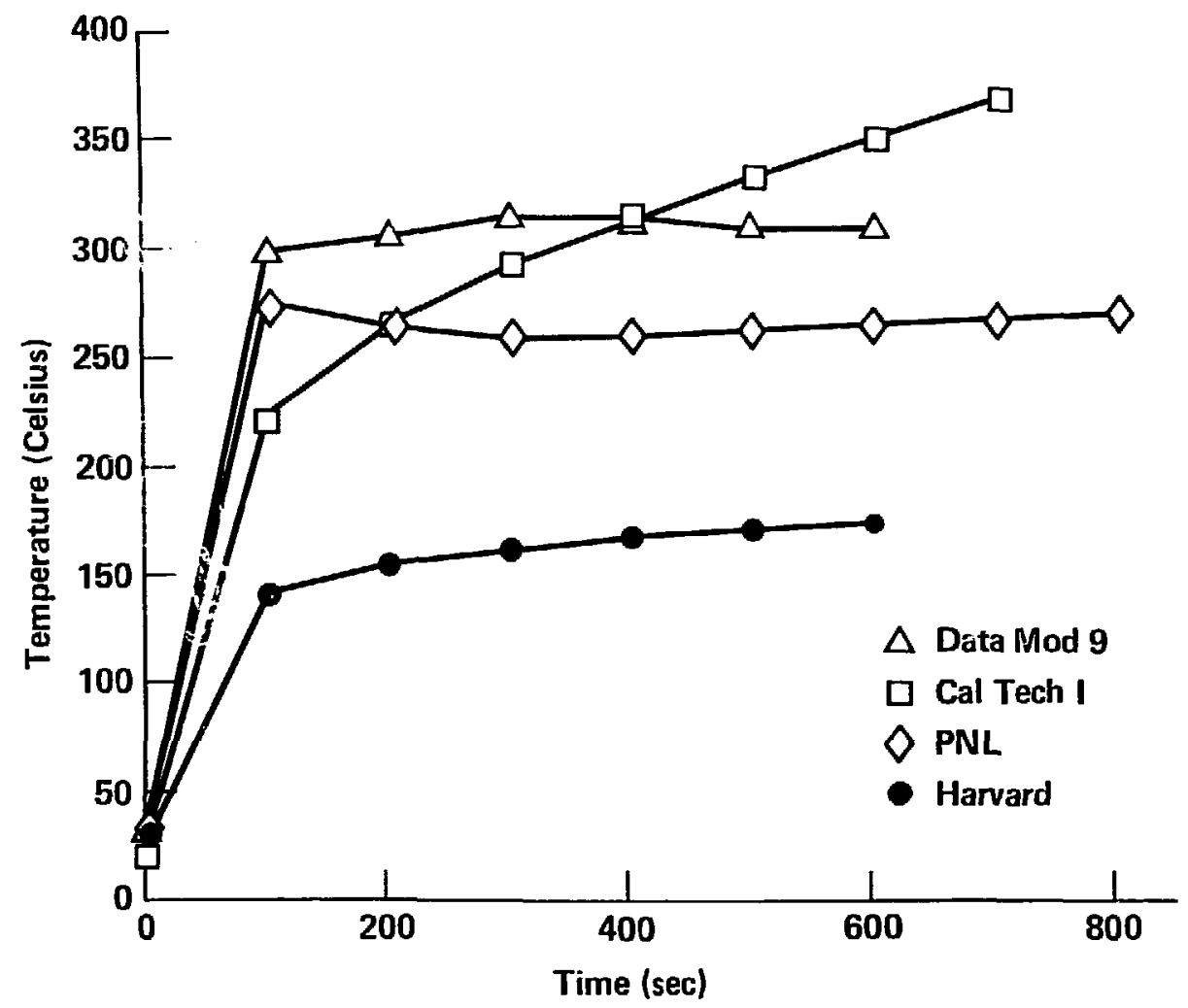

Figure A-13(b). Comparison of several models' gas temperature predictions for MOD 9B. 


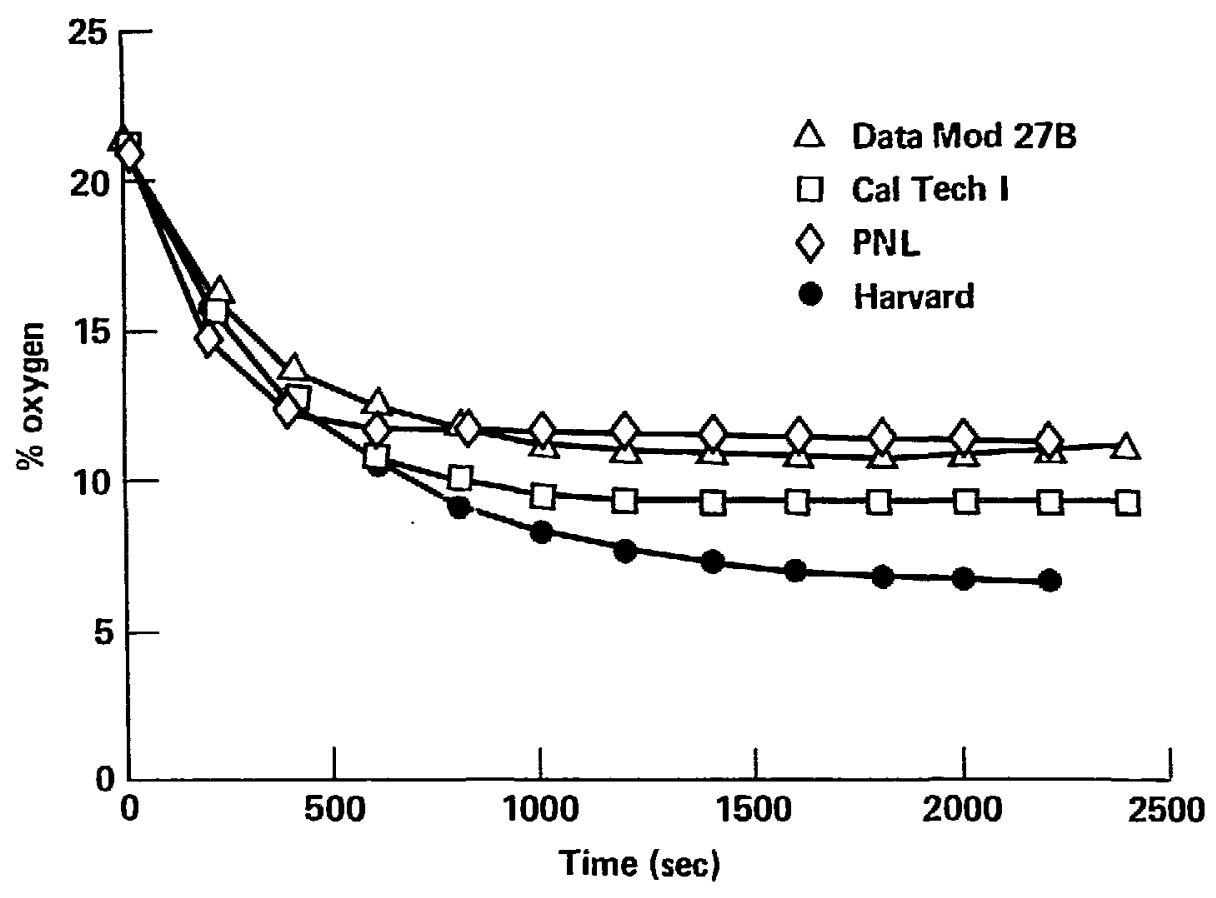

Figure A-14(a). Comparison of several models' oxygen depletion predictions for MOD 27B.

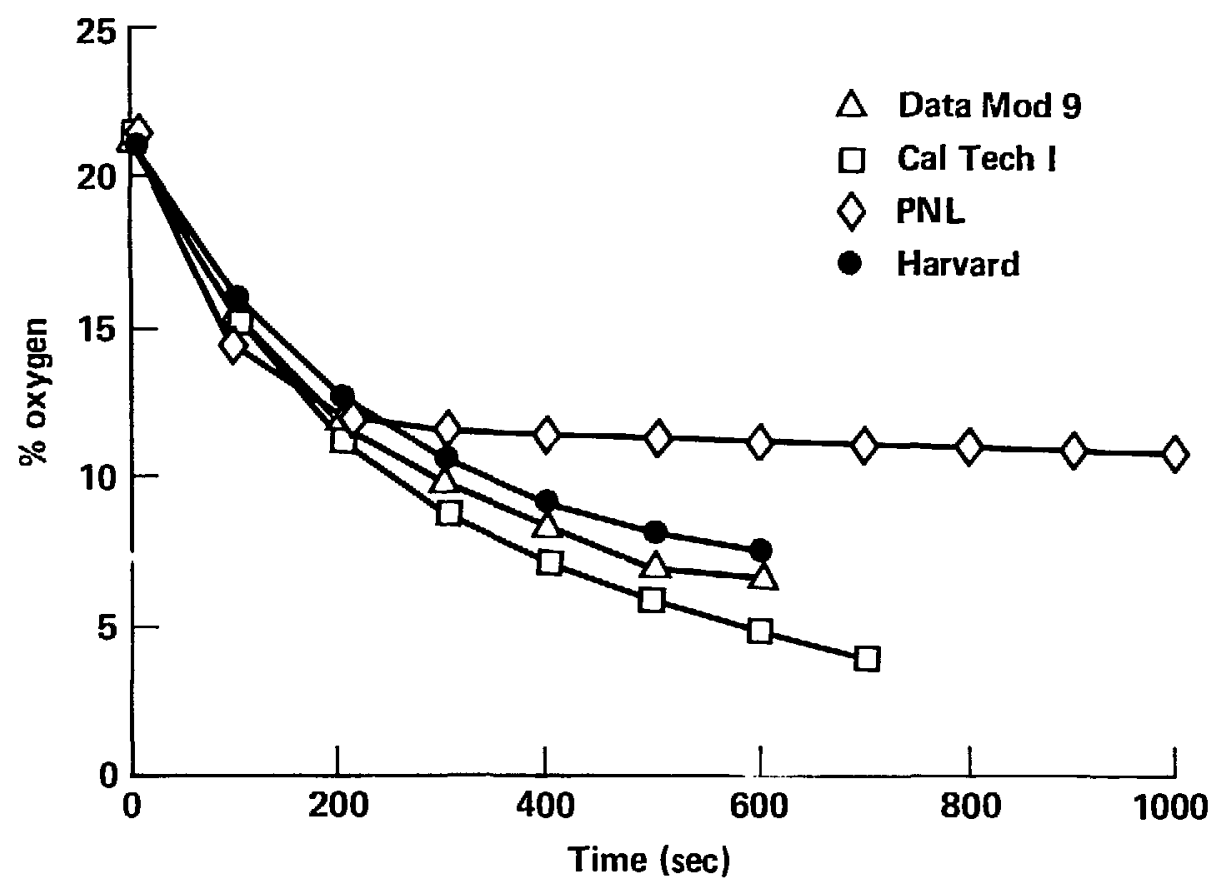

Figure A-14(b). Comparison of several models' oxygen depletion predictions for MOD 9. 


\section{Acknowledgments}

We wish to thank all the modelers who took interest and participated in the model-evaluation process. We particularly thank Professor E. E. Zukoski from Cal Tech and Dr. Dick Gregory, Dr. Fritz Krause and Mr. Dick Martirı from LANL for their help in designing the experimental series. We are grateful for the work done by Don Beason, Steve Priante and Kirk Staggs in setting up and performing the actual tests.

\section{References}

Alvares, N. J., Hasegawa, H. K., Lipska-Quinn, A. E., (1981), "Fire Protection Countermeasures for Containment Ventilation Systems," Proc. 16th DOE Nuc. Air Cleaning Conf., p. 1213-1277.

Alvares, N. J., Hasegawa, H. K., Lipska-Quinn, A. E., (1982). Fire Protection Research for Energy Technology Projects. Report UCRL-53179, LLNL, University of California, Livermore, 18-27.

Arpaci, V. S. (1966). Conduction Heat Transfer, Addison-Wesley, Reading, Mass. p. 307.

Cleary, W. M. (Ed). (1979). Industrial Ventilation, Edward Brothers, Inc., Ann Arbor, MI.

Cooper, L. Y. (1981). Heat Transfer from a Buoyant Plume to an Unconfined Ceiling, Paper 81-MT-7, 20th ASME-AICME, Nat'l. Heat Transfer Conf.

Cox, G. (1983). A Field Model of Fire and Its Application to Nuclear Containment Problems. Proc. CSNI Specialist Meeting, CSNI Report.

Creighton, J. R., (1982). Simplified Two-Layer Model for LLNL Test Cell, LLNL, University of California.

Krause, F. R., and Gregory, W. S. (1982). Simulation of Forced Ventilation Fires. Proc. 17th DOE Air Cleaning Conf., Paper 9-3.

Mitler, H. E., and Emmons, H. W. (1981). Documentation for CFCV, The Fifth Harvard Computer Fire Code. Nat'l. Bureau of Standards Report, NBS Grant, 67-9011.

Mitler, H. E. (1982). Simulation of Large Fires with Forced Ventilation. Fuel Cycle Facility Safety Research Program Review Meeting \#11, FMRC.

McGehee, D. (1983). Radiative and Convective : Teat Transfer in a Compartment Fire. LLNL Riport in press 1984.

Nikanja, M., and Greif, R. (1978). Heat Transfer During Piston Compression. Journal of Heat Transfer, Vol. 100, Aug. 1978, p. 527-530.

Orloff, L. (1981). Simplified Radiation Modeling of Pool Fires. 18th Combustion Symposium, p. 549-561, The Combustion Institute.

Orzawski, P. C., Chan, M. K. W., Ballinger, M. Y., (1982). FIRIN1 - A Fire Source Term Computer Code, Fuel Cycle Facility Safety Research Program Review Meeting \#11, FMRC.

Sumerton, W. M. (1958). Some Thermal Properties of Porous Rocks. AlME PET. TRANs. 213, p. 61.

Zukoski, E. E. and Kubota, T. (1975). An Experimental Investigation of the Heat Transfer from a Buoyant Gas Plume to a Horizontal Ceiling - Part 2: Effects of Cẹiling Layer. Cal. Inst. Tech. Nat. Bur. Stand. NBS. GRC 77-98.

Zukoski, E. E. and Kubota, T. (1980). Two-Layer Modeling of Smoke Movement in Building Fires. Fire and Materials, 4, p. 19.

Zukoski, E. E. (1982). Personal Correspondence. 


\section{Appendix B Mocho Standpipe Digraph}

The bold arrows in Fig. B-1 represent normal information flow and logic. That is, if the system is operating normally, these bold lines describe the normal cause-and-effect between dependent and independent system variables. The detailed system digraph is rearranged around the following control loops: (1) control loop to turn the lead pump on and off, (2) control loop to tiru the lag pump on and off, and (3) control loop to open and close the main coritrol valve.

\section{Disturbances and Upset Conditions}

After thes- control loops, which are negative feedback loops, are identified, events such as equipment and instrument failure are included. These events can affect the control loops by either creating a lowlevel condition in the standpipes or storage tanks, or can shut down the system. in by dashed lines. As described in Dunglinson et al., these are initiating events that upset conditions which in turn causes the Top Event to occur.

\section{Modeling Information Flow to the Operator in Bidg. 511}

Alarms in Bldg. 511 indicating upset conditions are modeled as feedforward loops. These feedforward loops symbolize mitigative actions the operator must take to isstore an adequate water supply such as (1) manually opening the main control valve, or (2) cutting in Zone 7 in the event of failure of the Mocho system. In order for the operator to fail to take the corrective action, failure of the alarm system or operator must occur. The events are modeled as zero gain events, symbolized by " 0 ." Zero gain events represent events which nullify the information flow. 


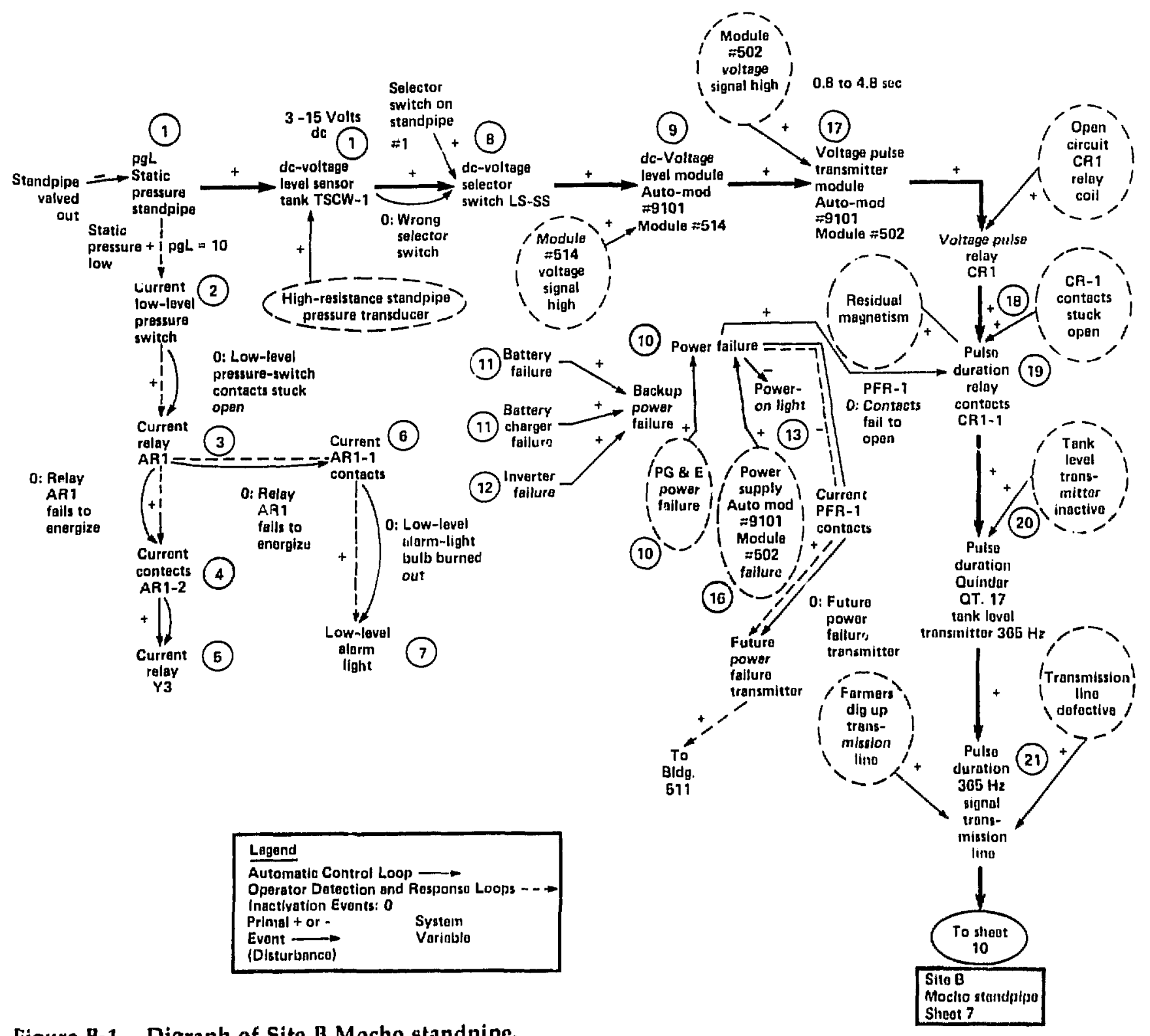

Figure B-1. Digraph of Site B Mocho standpipe. 


\section{Appendix C \\ Water-Supply-System Fault Tree}


Insufficient supply in storage

tank and no detection of

insufficient supply in Bldg. 511

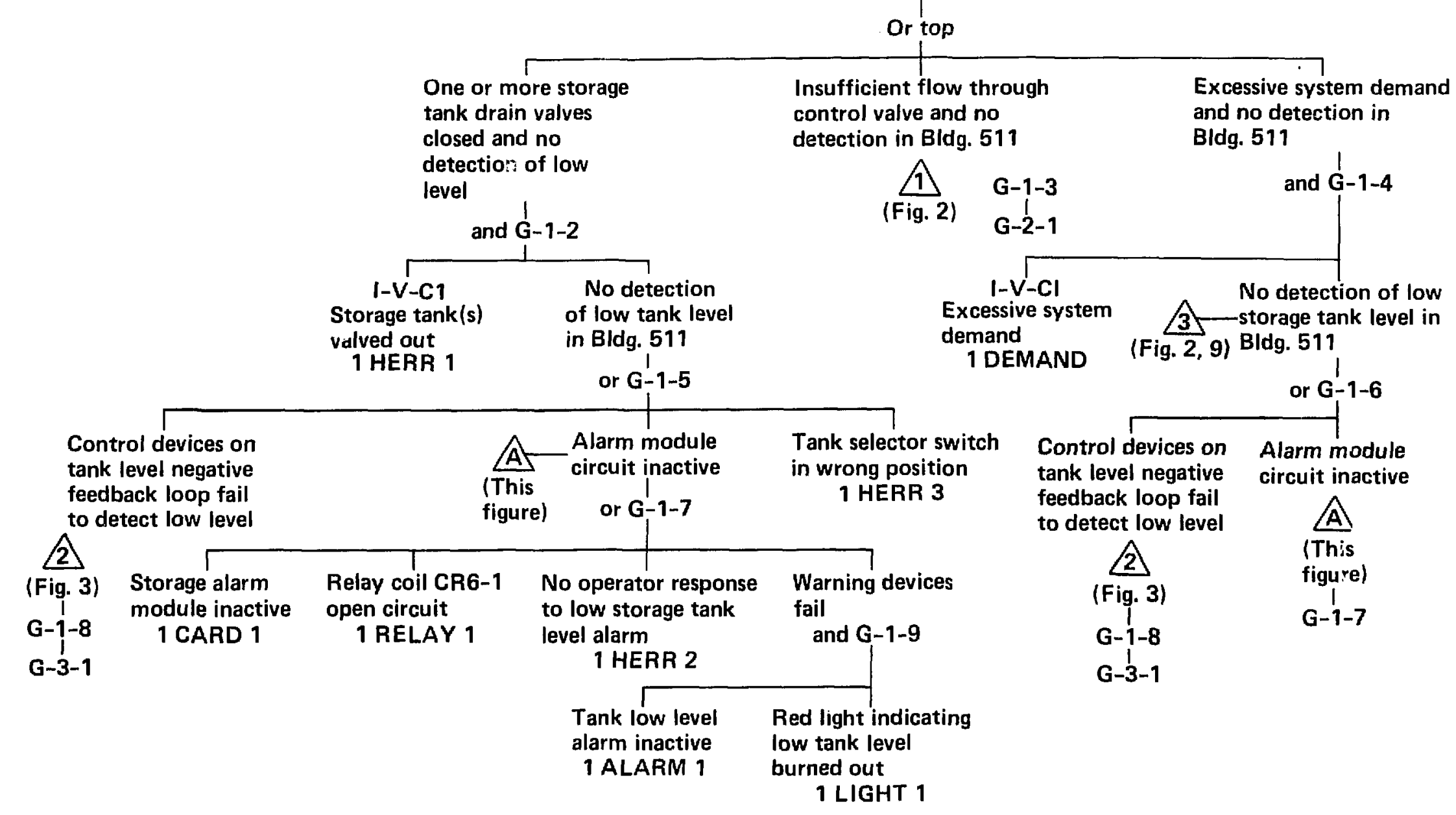




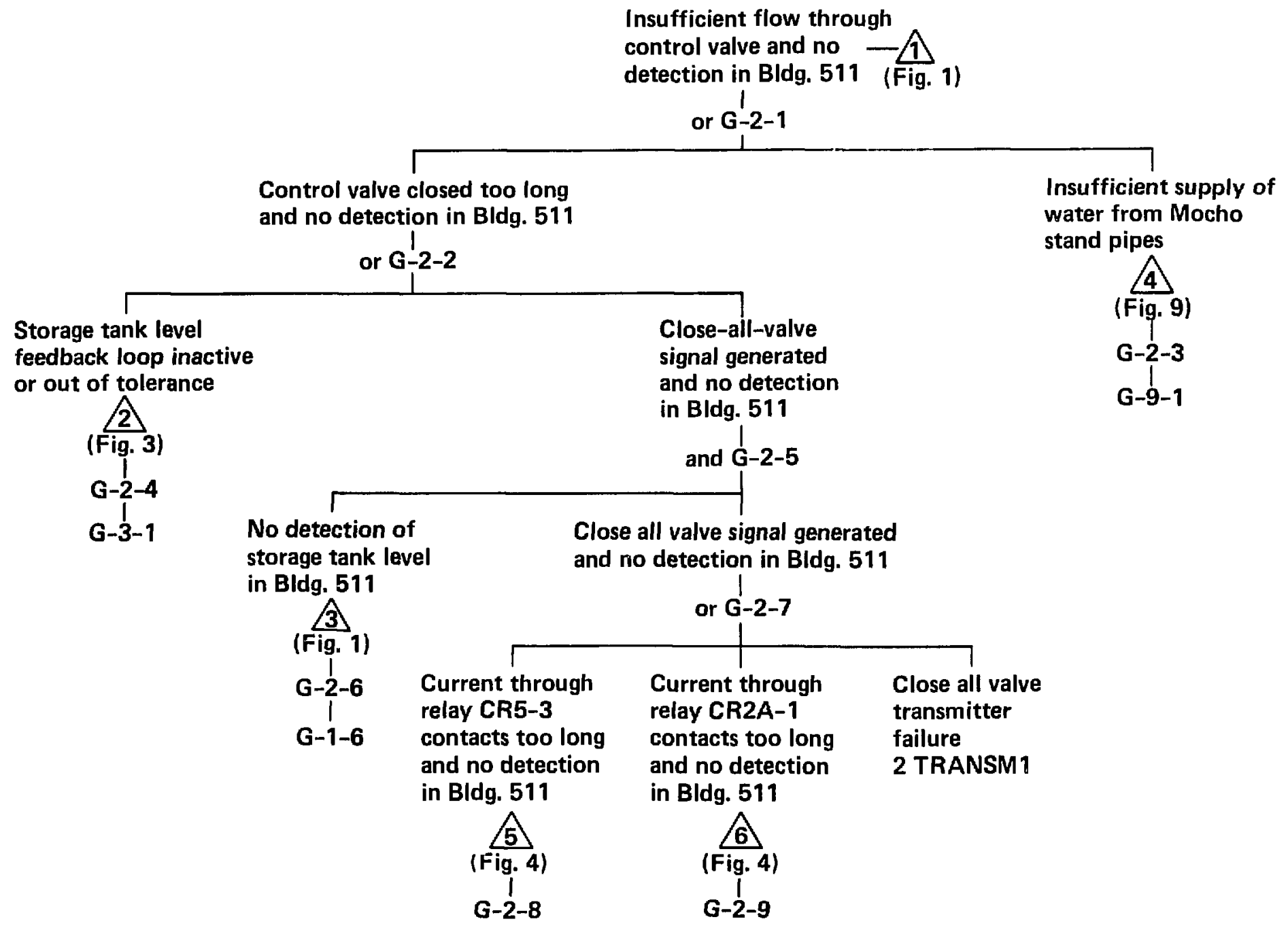




\section{Control devices on storage}

tank level negative feedback -2

loop inactive or fails out of

tolerance

$$
\text { (Fig. 1, 2) }
$$

$$
\text { or G-3-1 }
$$

$$
|-V-C|
$$

High resistance

WLT \#3 transducer

3 TRANSD 1

$$
1-\bar{V}-\mathrm{Cl}
$$

Level transmitter

fails low

3 TRANSM 1

\begin{tabular}{cc}
\hline \\
I-V-D2 \\
Valve module & F NOISE 1 \\
contacts open & selector switch opens \\
3 CARD 3 & 3 SWITCH 1 \\
\hline & I-V-C2 \\
I-V-C2 & Valve selector \\
2400 Hz receiver & switch contacts \\
fails low & transfer open \\
3 RECEIV 2 & 3 SWITCH 2
\end{tabular}

Tank level module voltage high 3 CARD 1

$$
\text { I-V-D2 }
$$

Noise on line to

control valve

transmitter

3 NOISE 1

3 SWITCH 2
$1-V-C$

Open circuit relay

relay CR1

3 RELAY 1

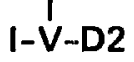

TCW storage tank

level receiver card voltage high 3 CARD 2

\section{I-V-D2}

Relay coil CA7

open circuit

3 RELAY 3

I-V-C2

Agastat TDR4-2

contacts transfer

open

3 RELAY 4

\section{$|-V-C|$}

Residual magnetism relay CR1

3 RELAY 2

\section{I-V-D2}

TCW storage tank

level receiver high

3 RECEIV 1

\section{I-V-D2}

Valve transmitter

fails low

3 TRANSM 2

I-V-C2

Valve

stem

failure

3 VALVE 1

$$
\Gamma
$$

Backup power

supply failure

or G-3-3

\begin{tabular}{ccc}
\multicolumn{3}{c}{} \\
$\begin{array}{c}\text { Inverter } \\
\text { failure }\end{array}$ & $\begin{array}{c}\text { Battery } \\
\text { failure }\end{array}$ & $\begin{array}{c}\text { Charger } \\
\text { failure }\end{array}$ \\
storage tank) & (storage tank) & (storage tank) \\
3 INVERT 1 & 3 BATT 1 & 3 CHARG 1
\end{tabular}

Power failure

and G-3-2

PG\&E failure

I-V-C1

3 PGE 1 


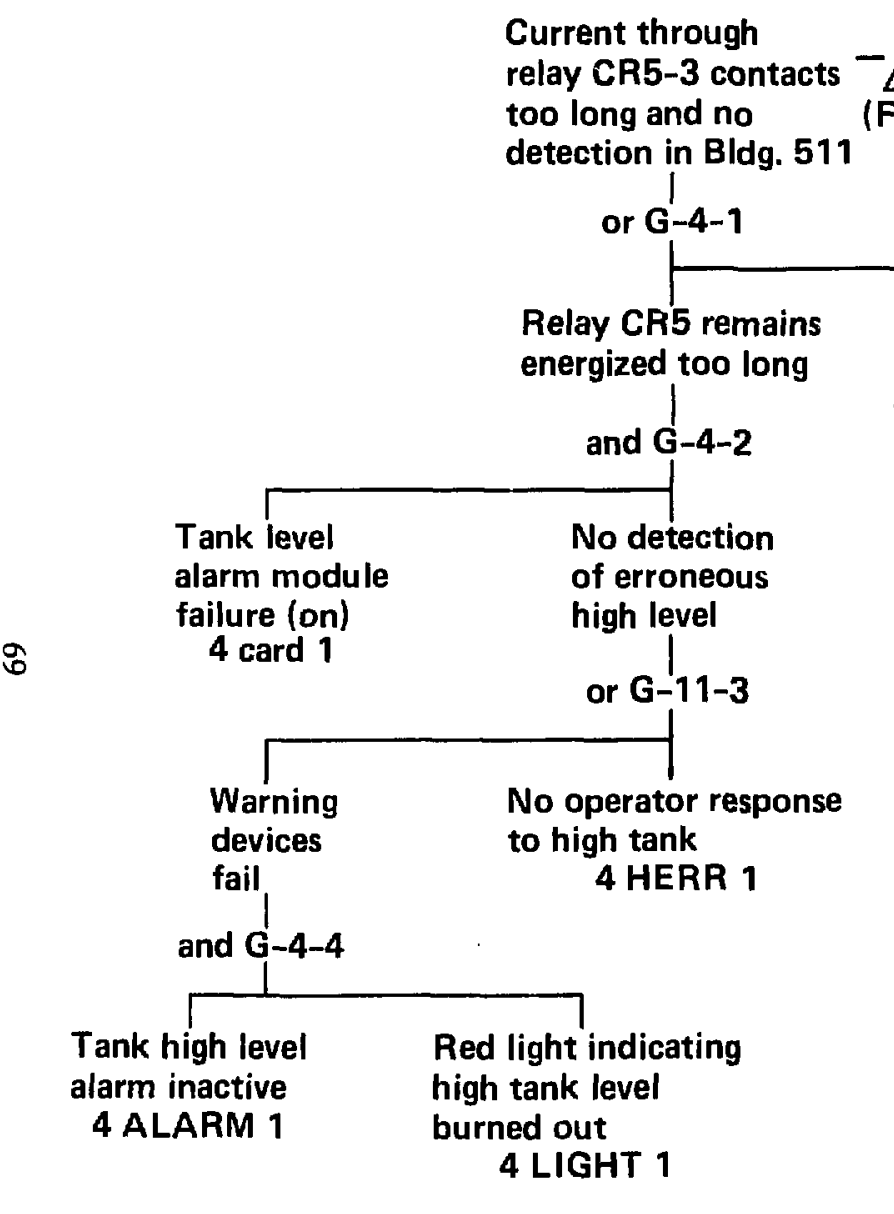

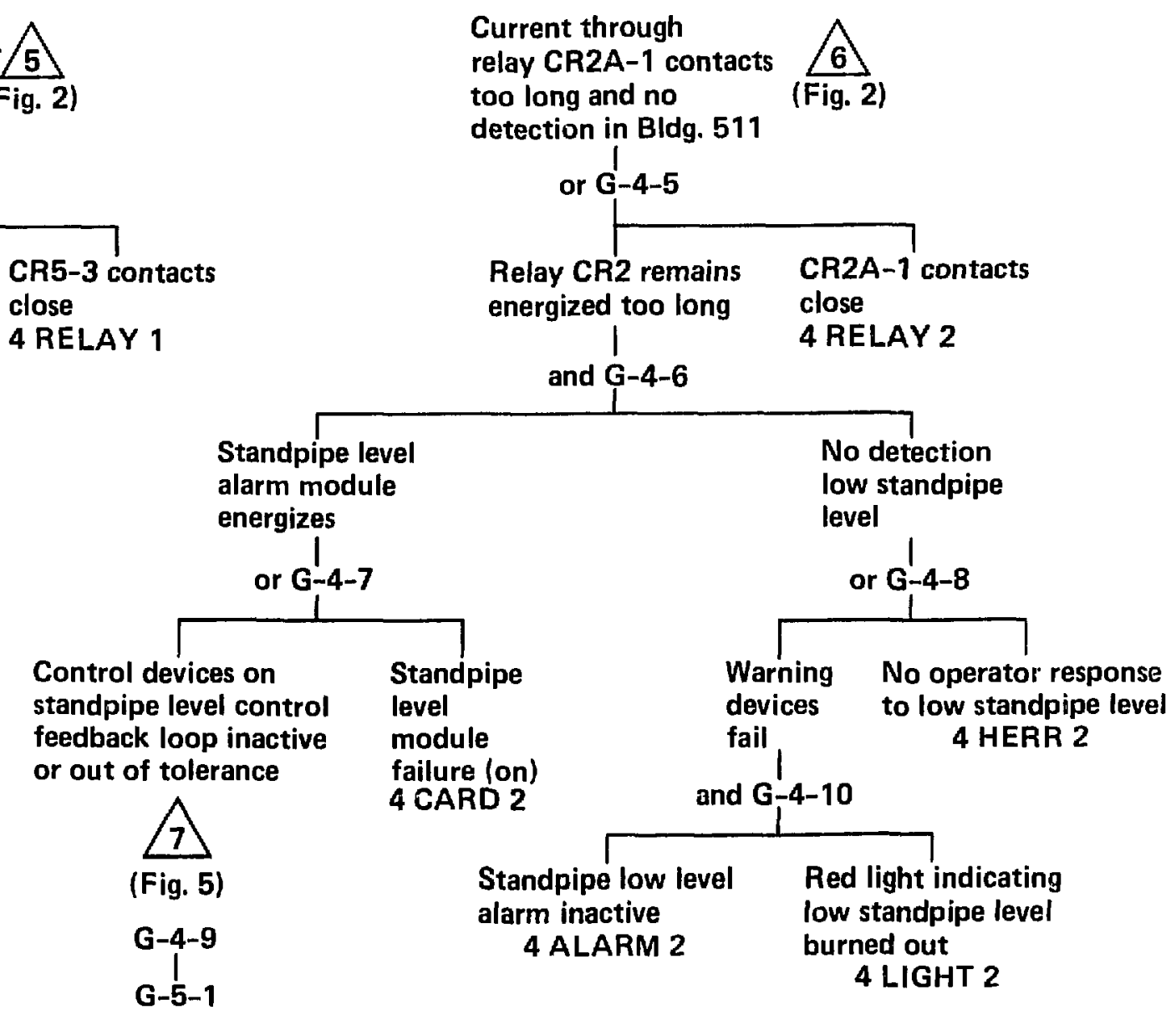


Control devices on siandpipe

level control inactive or out $\longrightarrow$

of tolerance

or G-5-1

I-P-B1 I-P-B1 I-P-B

High resistance standpipe pressure

transducer

5 TRANSD 1

Module \#514 voltage Module \#502 voltage signal high 5 CARD 1

Module $\# 502$ vo
signal hinh

5 CARD 2

I-P-B]

Residual magnetism

relay CRI

5 RELAY 1

$$
\text { I-P-B1 }
$$

Standpipe level

transmitter low

5 TRANSM 1

$$
\text { I-P-B1 }
$$

Farrners dig up

transmission line

$$
\text { I-P-D1 }
$$

$$
5 \text { DIG UP }
$$

$$
\text { I-P-B1 }
$$

I-P-B 1

Power supply Auto

mod \#9109 failure off 5 CARD 3

Noise

on line

$$
\text { I-P-DI }
$$

I-P-D1

5 NOISE

TSCW level receiver

voltage high

Pump switch module

voltage high

I-P-D1

CR3-2 contacts

transfer open

5 CARD 4

5 RELAY 2

CR1A-1 contacts

transfer open

5 RELAY 3

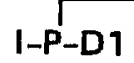

Auto contacts

transfer open

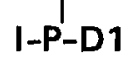

I-P-A1

CR4-3 contacts

transfer open

Lead pump receiver

failure -- off

5 SWITCH 1

5 RELAY 4

I-P-A1

I-P-A1

5 RECEIV 2

CR4-2 contacts

transfer open

Selector switch contacts

transfer open

I-P-A1

PSRG contacts

5 RELAY 5

5 SWITCH 3

transfer open

5 RELAY 6

$$
\text { I-P-A1 }
$$

Low level switch

transfers open

5 SWITCH 2

I-P-A1

CR5-2 contacts

transfer open

5 RELAY 7
I-P-A1

High pressure

switch contacts

transfer open

5 SWITCH 5

$$
\text { I-P-A] }
$$

PSR2-3 contacts

transfer open

5 RELAY 8
I-P-A1

Pump selector switch contacts transfer open

5 SWITCH 4

$$
\text { I-P-A1 }
$$

PSR 1-3 contacts

transfer open

5 RELAY 9

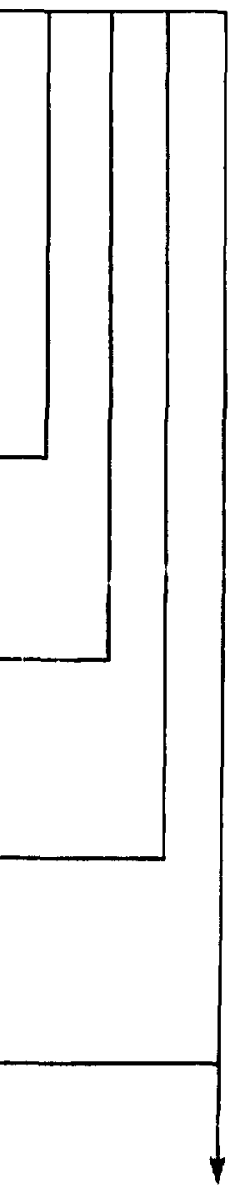

To Fig. 6 


\begin{tabular}{|c|c|c|c|}
\hline $\begin{array}{l}\text { I-P-A1 } \\
\text { PR3A-2 contacts } \\
\text { transfer open } \\
6 \text { RELAY } 1\end{array}$ & $\begin{array}{l}\text { I-P-A1 } \\
\text { TDPR3-1 contacts } \\
\text { transfer open } \\
6 \text { RELAY } 2\end{array}$ & $\begin{array}{c}\text { I-P-A1 } \\
\text { PCW \#3 motor } \\
\text { fails to function } \\
6 \text { MOTOR } 3\end{array}$ & $\begin{array}{c}\text { I-P-A1 } \\
\text { TDR3A-1 contacts } \\
\text { transfer open } \\
6 \text { RELAY } 3\end{array}$ \\
\hline $\begin{array}{l}\text { I-P-A1 } \\
\text { Agastat relay } \\
\text { TDR3 failure } \\
6 \text { RELAY } 4\end{array}$ & $\begin{array}{l}\text { I-P-A2 } \\
\text { Lag pump receiver } \\
\text { failure off } \\
6 \text { RECEIV } 1\end{array}$ & $\begin{array}{c}\text { I-P-A2 } \\
\text { PS-1 low level switch } \\
\text { transfer open } \\
6 \text { SWITCH } 1\end{array}$ & $\begin{array}{l}\text { I-P-A2 } \\
\text { CR4-2 contacts } \\
\text { transfer open } \\
6 \text { RELAY } 5\end{array}$ \\
\hline $\begin{array}{l}\text { I-P-A2 } \\
\text { Lag switch contacts } \\
\text { transfer open } \\
6 \text { SWITCH } 2\end{array}$ & $\begin{array}{c}\text { I-P-AZ } \\
\text { PSR-7 contacts } \\
\text { transfer open } \\
6 \text { RELAY } 6\end{array}$ & $\begin{array}{l}\text { I-P-A2 } \\
\text { PSR3-2 contacts } \\
\text { transfer open } \\
6 \text { RELAY } 7\end{array}$ & $\begin{array}{l}\text { 1-P-A2 } \\
\text { PSR 1-3 contacts } \\
\text { transfer open } \\
6 \text { RELAY } 8\end{array}$ \\
\hline $\begin{array}{c}\text { I-P-A2 } \\
\text { TDR1A-1 contacts } \\
\text { transfer open } \\
6 \text { RELAY } 9\end{array}$ & $\begin{array}{l}\text { I-P-A2 } \\
\text { PR1A-2 contacts } \\
\text { transfer open } \\
6 \text { RELAY } 10\end{array}$ & $\begin{array}{l}\text { I-P-A2 } \\
\text { TDPR1-1 contacts } \\
\text { transfer open } \\
\text { 6 RELAY } 11\end{array}$ & $\begin{array}{l}\text { I-P-A2 } \\
\text { PCW \#1 motor } \\
\text { fails to function } \\
\mathbf{G} \text { MOTOR } 1\end{array}$ \\
\hline $\begin{array}{l}\text { I-P-A2 } \\
\text { Agastat relay } \\
\text { TDR1 failure } \\
\text { 6 RELAY } 12\end{array}$ & $\begin{array}{l}\text { PCW \#3 failure signal } \\
\text { generated and no } \\
\text { response in Bldg. } 511\end{array}$ & $\begin{array}{l}\text { PCW \#1 failure signal } \\
\text { generated and no } \\
\text { response in Bldg. } 511\end{array}$ & \\
\hline
\end{tabular}




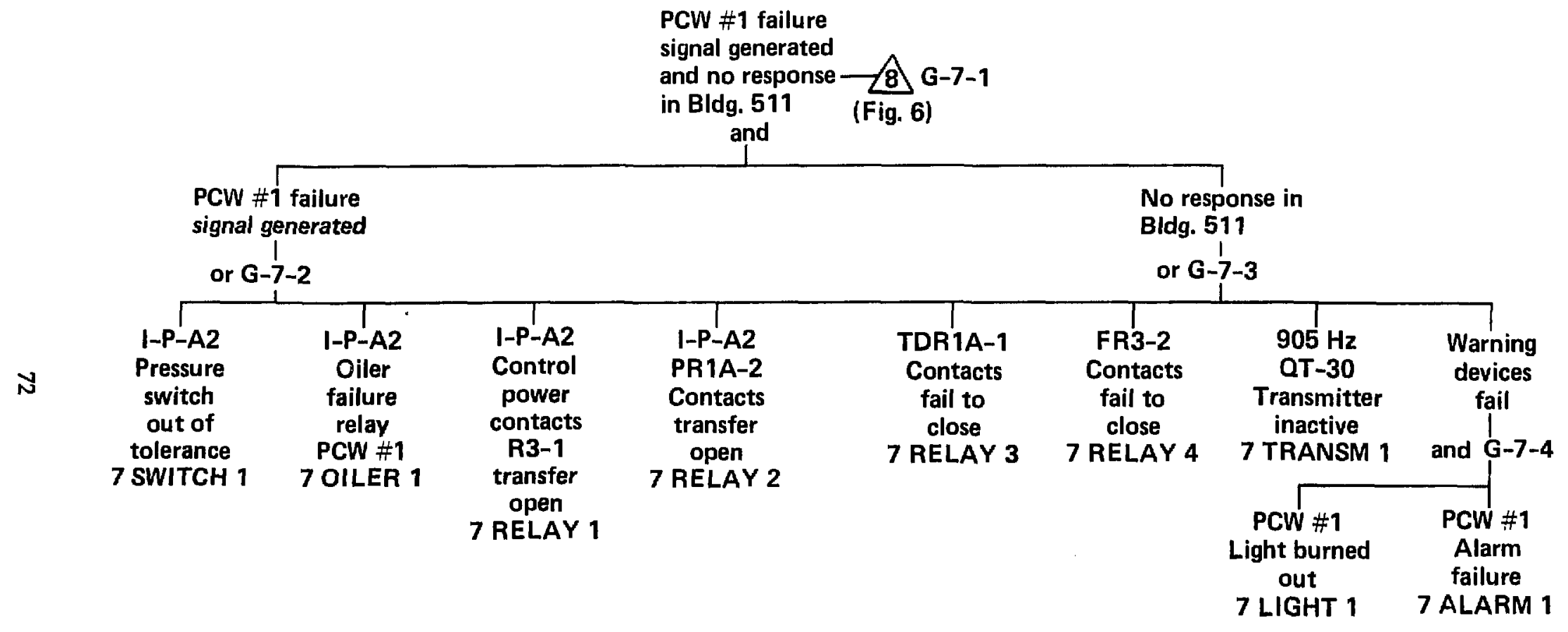




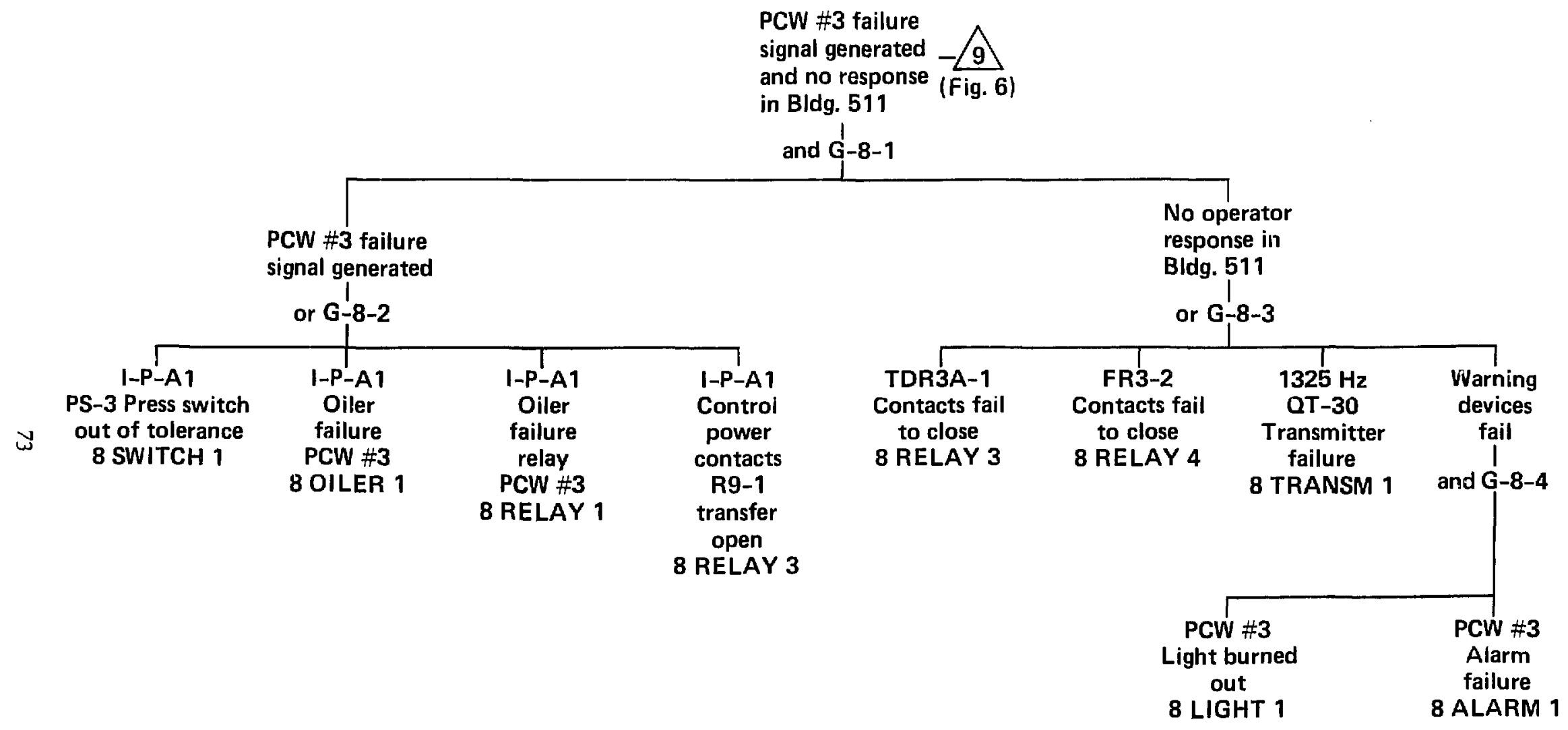


Insufficient supply

of water from
Mocho standpipes

$$
\text { and } \text { G-9-1 }
$$

Control value is

opened too long

I-P-1C2

Standpipe \#2 is

valved out

9 HERR
No detection of

low storage-tank level in Bldg. 511

$$
\begin{gathered}
\text { 3) } \\
\text { (Fig 1) } \\
\text { G-9-2 } \\
\text { G-1-6 }
\end{gathered}
$$

